\title{
WATER-QUALITY DATA-COLLECTION ACTIVITIES IN COLORADO AND OHIO: PHASE I--INVENTORY AND EVALUATION OF 1984 PROGRAMS AND COSTS
}

U.S. GEOLOGICAL SURVEY
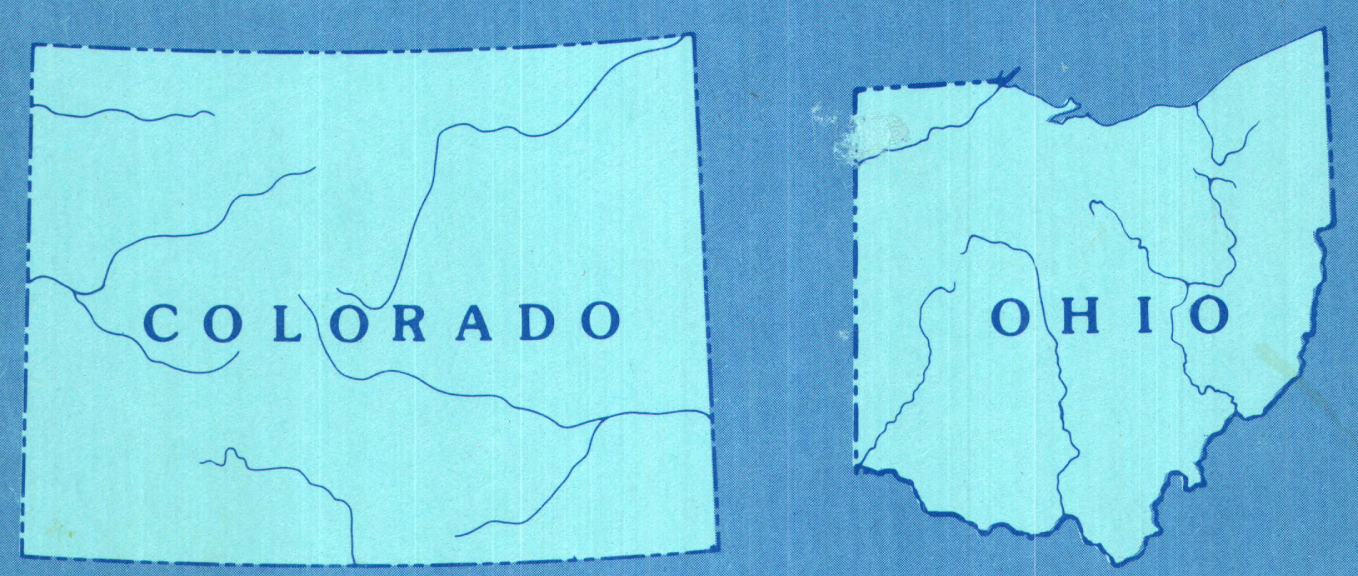

Open-File Report 85-574

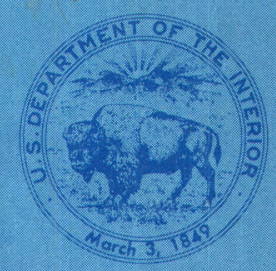





\section{ERRATA}

Open-File Report 85-574

WATER-QUALITY DATA-COLLECTION ACTIVITIES IN COLORADO AND OHIO: PHASE I--INVENTORY AND EVALUATION OF 1984 PROGRAMS AND COSTS

Page 3 Paragraph 1, line 9, change 36 percent to 31 percent.

Page 39 Paragraph 1, last sentence, change 12,000 to 8,400 .

Page 47 Paragraph 3, line 4, change 52 percent to 30 percent.

Page 48 Paragraph 2, line 4, change 93 percent to 77 percent.

Pages 78-81, 84-87; Tables 10-13, 16-19, headnote, "Samples collected to meet permit requirements not included;" should be deleted. Permitrequired samples are shown as a subtotal and included in "Totals" row. 
WATER-QUALITY DATA-COLLECTION ACTIVITIES IN COLORADO AND OHIO:

PHASE I--INVENTORY AND EVALUATION OF 1984 PROGRAMS AND COSTS

By Janet Hren, Thomas H. Chaney, J. Michael Norris, and Carolyn J. Oblinger Childress

U.S. GEOLOGICAL SURVEY

OPEN-FILE REPORT $85-574$ 
DEPARTMENT OF THE INTERIOR

DONALD PAUL HODEL, Secretary

U.S. GEOLOGICAL SURVEY

Dallas L. Peck, Director

For additional information write to:

Colorado District Chief U.S. Geological Survey Water Resources Division Box 25046, Mail Stop 415 Denver Federal Center Denver, Colorado 80225 or Ohio District Chief U.S. Geological Survey Water Resources Division 975 West Third Avenue Columbus, Ohio 43212
Copies of this report can be purchased from:

Open-File Services Section Western Distribution Branch U.S. Geological Survey Box 25425, Federal Center Denver, Colorado 80225 Telephone: (303) 236-7476 or

Text Products Section Eastern Distribution Branch 604 S. Pickett Street Alexandria, Virginia 22304-465 Telephone: (703) 557-2751 


\section{PREFACE}

One of the most important activities required for effective management of our Nation's water resources is the collection of sound, objective information to define the quality of surface and ground water. Many agencies collect water-quality data for a wide variety of purposes such as:

- define near-natural water-quality conditions;

- define existing water-quality conditions;

- detect trends and, therefore, possible improvements or potential issues;

- compute waterborne loads of constituents that are of concern;

- determine suitability of water for various uses;

- determine compliance with water-quality criteria and standards; and

- determine effectiveness of pollution-control programs.

The U.S. Geological Survey, with the cooperation of numerous Federal, State, and local agencies and universities has undertaken studies in two States to determine the characteristics of existing Federal and non-Federal water-quality data-collection programs and to determine the applicability and availability of these programs for addressing selected water-quality questions of regional and national scope.

This report presents the results of the first phase of an investigation in Colorado and Ohio to characterize current water-quality data-collection activities, including the cost of data acquisition, and to identify those data potentially applicable and readily available for addressing three major questions:

What are near-natural water-quality conditions?

What are existing water-quality conditions?

Has water quality changed?

The need for this study does not imply that past and current datacollection programs of agencies have failed or are inappropriate for their intended purposes. The data from those programs may fully meet individual agency needs and fulfill their mandated requirements, yet may have only limited value for addressing water-quality questions of regional and national scope. For example, in contrast to the emphasis of many water-quality datacollection programs on pollutants at specific sites or river reaches, the assessment of regional and national water-quality conditions commonly requires detailed information on current water-quality conditions throughout large areas, as well as knowledge about natural or predevelopment water-quality conditions.

More specifically, samples are often required to be collected from wastewater effluent or other point sources as part of the conditions of a water-related permit. For comparative purposes, and to be all-inclusive, this report includes estimates of these permit-required samples, even though there was never any expectation that they would be applicable to the study of water-quality questions of regional and national scope. 
Some of the intended audience for this report may not be familiar with all the technical terms associated with water-quality studies. To assist these readers, while avoiding a large number of definitions in the text, a brief glossary of the technical terms is provided for the readers' convenience.

A Supplemental Data section containing a study questionnaire, questionnaire instructions, and tables containing supporting data are at the back of the report.

The authors gratefully acknowledge the cooperation and assistance of the many Federal, State, regional, and local agencies and academic institutions that provided information for use in this report. 
Page

Preface----0--

Glossary--

Executive summary--

Introduction-

Background--

Project objectives and approach-

Phase I--Purpose and scope--

Methods of acquiring, compiling, and evaluating information---

Description of questionnaire-

Identification of organizations collecting water-quality data--- 9

Determination of water-quality data costs-

Screening criteria--

Organizations collecting water-quality data-

Colorado-

Ohio--

Comparison between States--

Purposes of water-quality data collection-

Colorado--

Ohio--

Comparison between States-

Types of water-quality determinations-

Colorado----

Ohio--

Comparison between States-

Costs of water-quality data-

Colorado-

Ohio--

Comparison between States-

Evaluation of water-quality data-

Colorado-0.-

Surface water- 36

Ground water-- 39

Ohio--

Surface water-

Ground water-

Comparison between States-

Summary and conclusions-

References--

Supplemental data-

Questionnaire-

Instructions for questionnaire-

Organizations collecting water-quality data--

Costs for parameters-

Screening results- 


\section{O N T E N T S}

\section{ILLUSTRATIONS}

Figure 1. Photographs showing different land uses that can affect

Page water quality: (A) Crop irrigation in eastern Colorado, and (B) strip mining for coal in eastern Ohio- 6

2. Charts showing distribution of water-quality samples reported during 1984 by organizational category:

(A) Colorado and (B) Ohio-- 16

3. Charts showing percentages of samples reported during 1984 for the purposes of meeting permit requirements, undertaking compliance-and-enforcement activities, or characterizing ambient conditions: (A) Colorado and (B) Ohio-n 20

4-7. Graphs showing:

4. Comparison of the numbers of water-quality samples reported for the purposes of meeting permit requirements, undertaking compliance-and-enforcement activities, or characterizing ambient conditions in Colorado and Ohio, 1984------- 22

5. Number of surface-water samples reported during 1984 by major property and constituent groups: (A) Colorado and (B) Ohio-- 24

6. Number of ground-water samples reported during 1984 by major property and constituent groups: (A) Colorado and (B) Ohio-- 25

7. Number of surface- and ground-water samples by major property and constituent groups, Colorado and Ohio, 1984-- 27

8. Charts showing percentages of estimated laboratory costs for the purposes of meeting permit requirements, undertaking compliance-and-enforcement activities, or characterizing ambient conditions during 1984: (A) Colorado and (B) Ohio---- 29

9. Graph showing estimated costs for laboratory analysis of surface- and ground-water samples, by property and constituent group, 1984: (A) Colorado and (B) Ohio-n-..- 32

10-13. Charts summarizing:

10. Screening results for Colorado and Ohio, 1984:

(A) surface-water samples, and (B) their estimated laboratory costs- 37

11. Screening results for surface-water samples for Federal, State, regional, and local agencies and academic institutions, 1984: (A) Colorado and

(B) Ohio- reening results for Colorado and Ohio, 1984:

12. Screening results for Colorado and Ohio, 1984:
(A) ground-water samples, and (B) their estimated

13. Screening results for ground-water samples for Federal, State, regional, and local agencies and academic institutions, 1984: (A) Colorado and (B) Ohio-n 4 


\section{O N T E N T S}

\section{TABLES}

Table 1. Numbers of organizations reporting water-quality data-collection programs and numbers of programs reported, Colorado, 1984----- 14

2. Numbers of organizations reporting water-quality data-collection programs and numbers of programs reported, Ohio, 1984----.- 17

3. Summary of estimated laboratory costs by organizational category, Colorado, 1984- 30

4. Summary of estimated laboratory costs by organizational category, Ohio, 1984- 33

5. Numbers and percentages of samples and estimated laboratory costs (surface water and ground water combined) before and after screening, by source of data, Colorado and Ohio, 1984---

6. Numbers and percentages of samples and estimated laboratory costs (surface water and ground water combined) before and after screening, by property and constituent groups, Colorado and Ohio, 1984-

7. Organizations with water-quality data-collection programs active in Colorado during 1984 and the property and constituent groups for which data are reported--

8. Organizations with water-quality data-collection programs active in Ohio during 1984 and the property and constituent groups for which data are reported-cos

9. U.S. Geological Survey laboratory codes, detection limits, and costs for measurements and analyses used to determine estimated laboratory costs--

10. Number of surface-water samples and estimated costs of: all measurements and analyses reported; those meeting either the ambient conditions or the data-availability criteria; and those meeting both screening criteria, by source of data, Colorado, 1984-1

11. Number of ground-water samples and estimated costs of: all measurements and analyses reported; those meeting either the ambient conditions or the data-availability criteria; and those meeting both screening criteria, by source of data, Colorado, 1984-1

12. Number of surface-water samples and estimated costs of: those meeting both the ambient conditions and the data-availability criteria and either the location, quality assurance, or the computerized criteria; and those meeting all five, by source of data, Colorado, 1984

13. Number of ground-water samples and estimated costs of: those
meeting both the ambient conditions and the data-availability criteria and either the location, quality assurance, or the computerized criteria; and those meeting all five, by source of data, Colorado, 1984- 
Table 14. Estimated surface-water-quality laboratory costs for ambient and compliance-and-enforcement programs, after screening, for physical properties and major-constituent groups, Colorado, 1984-

15. Estimated ground-water-quality laboratory costs for ambient and compliance-and-enforcement programs, after screening, for physical properties and major-constituent groups, Colorado, 1984--

16. Number of surface-water samples and estimated costs of: all measurements and analyses reported; those meeting either the ambient conditions or the data-availability criteria; and those meeting both screening criteria, by source of data, Ohio, 1984-1

17. Number of ground-water samples and estimated costs of: all measurements and analyses reported; those meeting either the ambient conditions or the data-availability criteria; and those meeting both screening criteria, by source of data, Ohio, 1984-

18. Number of surface-water samples and estimated costs of: those meeting both the ambient conditions and the data-availability criteria and either the location, quality assurance, or the computerized criteria; and those meeting all five, by source of data, Ohio, 1984-

19. Number of ground-water samples and estimated costs of: those meeting both the ambient conditions and the data-availability criteria and either the location, quality assurance, or the computerized criteria; and those meeting all five, by source of data, Ohio, 1984-

20. Estimated surface-water-quality laboratory costs for ambient and compliance-and-enforcement programs, after screening, for physical properties and major-constituent groups, Ohio, 1984-1

21. Estimated ground-water-quality laboratory costs for ambient and compliance-and-enforcement programs, after screening, for physical properties and major-constituent groups, Ohio, 1984- 
Terms defined in the glossary are in bold print when first used in the main body of this report.

ambient.--Conditions that are representative of the existing water quality of a given stream reach or area of an aquifer.

analysis.--A laboratory procedure performed on a water sample to determine the proportion or concentration of the total, dissolved, or suspended constituents.

biota.--Flora and fauna occurring in a region (such as bacteria, algae, invertebrates, and other organisms); in this report refers to organisms found in streams, lakes, or other water bodies, and in the case of aquifers, bacteria.

compliance and enforcement.--Water-quality data-collection activities that are undertaken by a regulatory agency to insure that a permit or other statutory requirement is being met.

data base.--An assemblage of water-quality information collected by an agency or institution and maintained in computer files or as paper records.

effluent.--Treated or untreated waste material discharged into the environment. Examples include discharges from water or wastewatertreatment plants, industrial complexes, or landfills.

inorganic constituents.--All those combinations of elements that do not include organic carbon.

major metals.--Metals that commonly occur naturally in concentrations greater than 1 milligram per liter; in this report, either or both of the constituents, iron and manganese.

nutrients.--Any substance that is assimilated by organisms and promotes growth; generally applied to any or all of the constituents that contain nitrogen or phosphorus, such as ammonia, nitrite, or orthophosphate.

organic substances.--Any or all of the groups of compounds containing carbon as identified by tests for the following: organic and inorganic carbon, oil and grease, Biochemical Oxygen Demand, detergents, tannin and lignin, phenols, and similar compounds such as pesticides.

permit-required.--Water-quality data-collection activities that are undertaken by a permit holder in partial fulfillment of the legal requirements of a permit allowing the discharge of effluent or other modified waters. Water-quality monitoring mandated by a National Pollution Discharge Elimination System (NPDES) permit issued to a point-source discharger is an example of a permit-required data-collection activity.

pesticides.--Any of the specific organic compounds used to kill insect or plant pests, such as organochlorine insecticides or triazine herbicides. physical properties.--Water properties that are characterized by measurements such as: temperature $\mathrm{pH}$, dissolved oxygen, turbidity, alkalinity, and specific conductance. These measurements generally are made at a datacollection site but may also be measured in a laboratory.

priority pollutants.--Organic compounds comprising any or all of the following pollutant groups: acid- and base-extractable compounds, volatile compounds, and other groups as identified by the U.S. Environmental Protection Agency.

quality assurance. --Systematic testing of a water-quality laboratory's analytical methods and accuracy through analysis of replicate samples, samples with known concentrations, and other reference samples. 
radiochemicals.--Constituents whose presence is indicated by the measurement of gross-alpha radioactivity and by tests for specific radioactive elements.

salinity.--A measure of the concentration of dissolved mineral substances in water, particularly salts containing sodium or chloride.

sample.--A volume of water, collected from and representative of a stream, lake, aquifer, or effluent discharge, that may be measured for a number of different properties or that may be analyzed for a number of different constituents, or both.

sediment.--Any or all of the following particulate matter in water: suspended sediment, bed material, bed load, and total sediment load.

trace elements.--Metals and similar elements that routinely occur in nature in concentrations less than 1 milligram per liter, including any or all of the following: aluminum, arsenic, chromium, copper, lead, mercury, nickel, selenium, zinc, and similar elements. 
By Janet Hren, Thomas H. Chaney, J. Michael Norris, and Carolyn J. Oblinger Childress

\section{EXECUTIVE SUMMARY}

Serious questions have been raised by Congress about the usefulness of water-quality data for addressing issues of regional and national scope and, especially, for characterizing the current quality of the Nation's streams and ground water. In response, the U.S. Geological Survey has undertaken a pilot project in Colorado and Ohio to: (1) Determine the characteristics of current water-quality data-collection activities of Federal, State, and local agencies, and universities; and (2) determine how well the data from these activities, collected for various purposes and using different procedures, can be used to improve our ability to answer three major questions:

What are near-natural water-quality conditions?

What are existing water-quality conditions?

Has water quality changed?

Colorado and Ohio were chosen for the pilot project because they represent regions with different types of water-quality issues and programs. The results of the project are specific to the two States and are not intended to be exprapolated to other States.

The project has been divided into three phases whose objectives are: Phase I--identify and inventory 1984 water-quality data-collection programs, including costs, in Colorado and Ohio, and identify those programs that meet a set of broad criteria appropriate for addressing selected water-quality questions of regional and national scope; Phase II--evaluate the quality assurance of sample-collection techniques and laboratory methods used to compile the data bases that meet Phase I criteria; Phase III--evaluate the applicability of these qualifying data bases to address the aforementioned three specific water-quality questions of regional and national scope and demonstrate the use of these data.

This report presents the results of Phase I by characterizing current water-quality data-collection activities in Colorado and Ohio, including costs of sample analyses, and identifies those data potentially applicable and readily available to address selected water-quality questions of regional and national scope.

Forty-eight organizations with 115 programs were identified in Colorado, and 42 organizations with 88 programs were identified in Ohio. About four times more samples were reported in Ohio than in Colorado, principally because of more National Pollution Discharge Elimination System permits in Ohio. Surface-water samples represented 90 percent of all samples reported in Colorado and 96 percent of the samples reported in Ohio for the general purposes of: (1) Meeting permit requirements, (2) undertaking compliance-and- 
enforcement activities, and (3) characterizing ambient water-quality conditions. In Colorado, State agencies reported the largest number of surface-water samples; Federal agencies reported the largest number of groundwater samples. In Ohio, local agencies reported the largest number of both surface- and ground-water samples.

The largest number of surface-water samples were collected for the analysis of physical properties and inorganic constituents in both Colorado and Ohio. For ground water, samples were analyzed most frequently in Colorado for biota, physical properties, and inorganic constituents; samples were analyzed most frequently in Ohio for biota and major metals. Among the least frequently analyzed, in both States, were the most costly analyses: priority pollutants and pesticides.

The total costs of water-quality data-collection programs in the two States were largely indeterminate but ranged widely among the different agencies, mainly because of the different kinds of costs that were included. The only reasonable basis for comparison was the numbers of samples and the types of analyses or measurements, as reported on the questionnaires. The reported analytical costs also were incomplete and inconsistent. Therefore, in order to standardize the comparisons, costs for laboratory analyses of samples were estimated using 1984 U.S. Geological Survey Central Laboratory prices. In Colorado, based on the total estimated laboratory costs, 45 percent of the laboratory costs were spent on permit-required samples; 17 percent of the laboratory costs were spent on compliance-and-enforcement activities; and 38 percent of the laboratory costs were expended to characterize ambient conditions. In Ohio, 72 percent of the estimated laboratory costs were spent on permit-required samples; 2 percent of the laboratory costs were spent on compliance-and-enforcement activities; and 26 percent of the laboratory costs were spent on characterization of ambient conditions.

A total of about $\$ 63$ million was estimated to have been spent during 1984 in the two States for the laboratory analysis of water-quality samples. Of this, about $\$ 42$ million was spent specifically to meet permit requirements. Water-quality analyses resulting from permit-required sampling, by themselves, generally are not considered useful for assessing ambient water quality because they represent effluent water conditions rather than ambient stream or aquifer conditions. However, when used with predictive techniques and in conjunction with instream water-quality data, effluent samples are useful for conducting certain water-quality evaluations. For example, effluent analyses are useful for reach-specific water-quality modelling and waste-load allocation studies and regional and national water-quality assessments to evaluate alternative wastewater treatment technology. Of the estimated $\$ 21$ million spent during 1984 for analyses of samples collected to characterize ambient conditions or for compliance-and-enforcement activities in the two States, about $\$ 8$ million represents the laboratory costs for data that are potentially applicable to and readily available for the examination of the previously identified water-quality questions of regional and national scope. These laboratory costs represent only a part, generally less than 50 percent, of the total cost of water-quality data-collection programs. 
Water-quality data-collection programs were tested against a set of five screening criteria to evaluate their potential applicability and availability for addressing water-quality questions of regional and national scope. The five criteria are: (1) Do the data represent ambient stream or aquifer conditions, as opposed to wastewater effluent or treated water? (2) Are the data available for public use? (3) Can sampling sites be readily located? (4) Is quality-assurance documentation available? and (5) Are the data in computer files? In Colorado, 34 percent of all samples met all five criteria and accounted for 36 percent of total estimated laboratory costs. In Ohio, 5 percent of all samples met all five criteria and represented 6 percent of estimated laboratory costs. When the permit-required samples are excluded, the samples meeting all criteria represent 63 percent of the total in Colorado and 30 percent of the total in Ohio. Most samples did not meet the ambientconditions criterion. Excluding permit-required samples, local agencies in both States had the smallest number of samples meeting all criteria.

A compilation of all available data in 1984 indicates that about 114,000 samples in Colorado and 57,000 samples in Ohio are potentially applicable to and readily available for analyses of selected water-quality questions of regional and national scope. By computerizing all water-quality data, the amount of readily available water-quality data can be increased by about 8 percent in Colorado and by 98 percent in Ohio. This large difference between the two States seems to be related to the relative amounts of data collected by each level of government. Federal agencies have a larger role in the collection of water-quality data in Colorado than in Ohio. Federal agencies currently computerize more water-quality data than do local agencies, probably because of the need to collect and interpret large amounts of information on a national scale. 
Increasing concerns about the quality of the surface- and ground-water resources in the United States have led to water-related Federal legislation such as the Clean Water Act (1972, amended 1977, 1981), the Safe Drinking Water Act (1974), the Resource Conservation and Recovery Act (1976), the Toxic Substances Control Act (1976), and the Comprehensive Environmental Response, Compensation, and Liability Act (1980). Billions of dollars have been spent by various agencies on different types of water-quality data-collection programs in support of this legislation and for various other purposes. In recent years, there has been considerable interest by Congress in assessing the effects of man's activities and pollution-control programs on water quality, and in the programs designed to monitor water quality. In 1983, the U.S. House of Representatives Subcommittee on Natural Resources, Agriculture Research, and Environment held hearings on national environmental monitoring. At these-hearings, monitoring programs were criticized as being "fragmented, duplicative, and wasteful, and in many cases, ...devoid of scientific validity and leadership" (Blodgett, 1983, p. 3).

Insufficient information has been available to determine whether these criticisms are accurate. Accordingly, the U.S. Geological Survey has undertaken a pilot program in two States to determine the extent to which existing water data can be aggregated for use in addressing selected waterquality questions of regional and national scope.

\section{Background}

The term, water-quality data, can include a wide array of data on physical, chemical, and biological characteristics, which generally are defined in terms of the intended water use. Drinking-water supply, industrial uses, irrigation, recreation, and habitat for aquatic life are among the water uses that usually require a certain standard of water quality. These water uses may also, in turn, affect the quality of water in streams, lakes, and aquifers. 
Water-quality data are collected by various Federal, State, regional, and local agencies, and by academic institutions and private-sector organizations for different purposes or mandates. Many of these water-quality programs focus on specific geographical areas with known or suspected pollution issues. Examples of water-quality data-collection programs include: (1) End-of-pipe sampling of wastewater effluent required by National Pollution Discharge Elimination System (NPDES) permits; (2) sampling of effluent, streams, or ground water to determine compliance with water-quality criteria and standards established by Federal or State legislation; and (3) sampling to define ambient water-quality conditions and trends by means of fixed-station, fixed-interval networks.

Emphasis on the use of and the needs for water-quality data has changed with time. In many streams, serious surface-water-quality problems of the past, such as decreased concentrations of dissolved oxygen and large bacteria counts, seem to be much less extensive today as a result of pollution-control programs of recent years. However, concerns are increasing about the contribution to pollution from nonpoint sources (agriculture, mining, and urbanization) and the pollution of surface and ground water by synthetic organic chemicals and potentially toxic metals (fig. 1). As new concerns have arisen, many agencies involved in water-quality data collection have adjusted their programs, sometimes changing the location of sampling sites, the frequency of data collection, or the constituents to be identified. These changes are determined by the new issue of concern and an agency's mission, responsibilities, and available resources.

\section{Project Objectives and Approach}

The objective of this study is to determine the extent to which existing water data, collected by different groups for various purposes and using different procedures, can be aggregated for use in addressing selected waterquality questions of regional and national scope. Specific goals are to:

1. Determine the characteristics of current (1984) water-quality programs, including methods of sample collection, laboratory analysis, and data storage by Federal, State, regional, and local agencies, and by academic institutions .

2. Determine the costs of water-quality data-collection programs.

3. Evaluate the applicability of existing data for addressing selected water-quality questions of regional and national scope. 


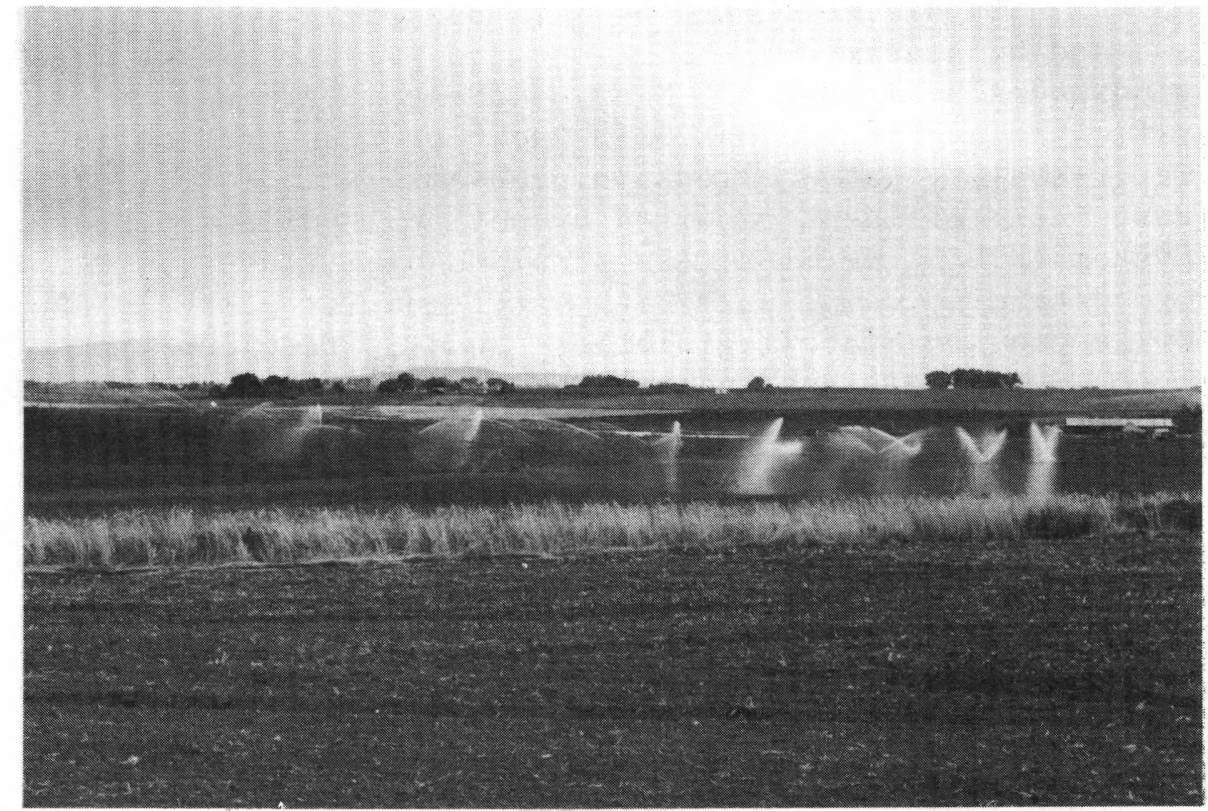

A

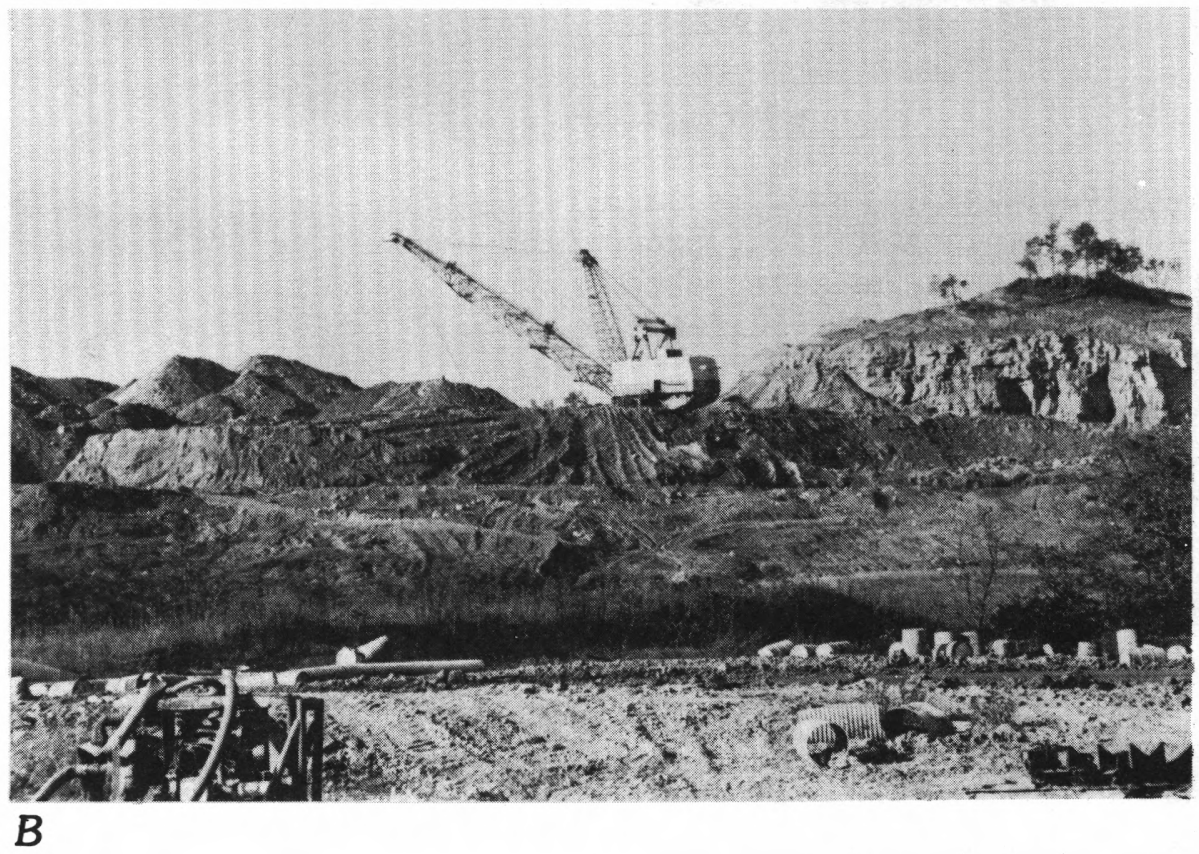

Figure 1.--Different land uses that can affect water quality: (A) Crop irrigation in eastern Colorado (photograph by K. E. Cohan, U.S. Geological Survey), and (B) strip mining for coal in eastern Ohio (photograph courtesy of R. P. Frehs, U.S. Geological Survey). 
A three-phase approach was used. The objectives of these phases are:

Phase I. Identify and inventory water-quality data-collection programs, including costs, and identify those programs that meet a set of broad criteria for conducting water-quality assessments.

Phase II. Evaluate the quality assurance of sampling techniques and laboratory methods used in collecting the data that meet the broad criteria of Phase I.

Phase III. Evaluate the applicability of these qualifying data for addressing selected water-quality questions of regional and national scope.

Two States, Colorado and Ohio, were chosen to serve as a small sampling of the Nation. These States represent regions with different types of waterquality issues and programs. Colorado, which has a population of about 3 million (U.S. Bureau of the Census, 1981a), is a lightly industrialized, western State with 36 percent federally owned lands (U.S. Bureau of Land Management, 1983). During 1980, freshwater withdrawals in Colorado were 16 billion gallons per day ( 81 percent surface water, 19 percent ground water) for public supply, rural domestic and livestock, industrial, and irrigation uses (Solley and others, 1983, p. 38). Eighty-eight percent of the water was used for irrigation and 6 percent for industry (thermoelectric and other industries included). Major water-quality issues in Colorado are associated with irrigation return flows (salinity) and minerals mining (sediment and trace elements).

Ohio, which has a population of about 10.8 million (U.S. Bureau of the Census, 1981b), is an industrialized eastern State with about 1 percent federally owned lands (U.S. Bureau of Land Management, 1983). In Ohio, 1980 freshwater withdrawals were 14 billion gallons per day (93 percent surface water, 7 percent ground water) (Solley and others, 1983, p. 38). Eighty-six percent was for industrial uses (thermoelectric and other industries included) and less than 1 percent for irrigation. Major water-quality issues in Ohio are related to the potentially toxic trace elements and organic substances sometimes associated with industrial discharge, and to agricultural runoff (nutrients and pesticides), coal mining (acidity and sediment), and urban runoff (bacteria, trace elements, and nutrients).

\section{Phase I--Purpose and Scope}

The purpose of this report is to characterize current (1984) waterquality data-collection programs and related costs in Colorado and Ohio and to identify those data potentially applicable to and readily available for addressing selected water-quality questions of regional and national scope. The results of the project are specific to the two States and are not intended to be extrapolated to other States. 


\section{Description of Questionnaire}

The main source of information for this report was a questionnaire ("Supplemental Data" section at back of report) developed by the U.S. Geological Survey and completed principally through interviews with public agencies and academic institutions involved in water-quality data-collection activities. A separate questionnaire was completed for each data-collection program that was active during 1984. For this purpose, a water-quality data-collection program was defined as a set of water-quality data-collection activities with an identifiable budget and objectives. The questionnaire contains five main sections. The purpose of the first section of the questionnaire was to obtain information on the scope, objectives, and cost of each organization's water-quality data-collection activities. The four remaining questionnaire sections were designed to obtain information specific to different categories of water-quality data: physical measurements, chemical analyses, biological determinations, and sediment analyses. Instructions that were supplied for completing the questionnaire are in the "Supplemental Data" section at the back of the report.

Each of the water-quality data-collection categories in the questionnaire is subdivided into specific groups of water-quality properties and constituents. These groups include physical properties, inorganic constituents, trace elements, nutrients, organic substances, radiochemicals, biota, and sediment (see Glossary). The measurements or constituents in each group are shown in the questionnaire ("Supplemental Data" section). For each group, the questionnaire respondent was asked to identify the number of sites sampled, the types of sites sampled, the frequency of sample collection, and the method of data storage. In compiling the questionnaire responses, it was deemed necessary to create a new constituent group, major metals, by separating out the number of samples in the trace-element group that included iron or manganese or both, either alone or in combination with the other trace elements. Consequently, the number of samples presented in the report for the traceelement group excludes all responses that indicated samples analyzed for only iron or manganese or both. This was done in order to segregate iron and manganese from the other, potentially more toxic elements included in the trace-element group. Also, the organic constituent responses were compiled in the following categories: organic substances, priority pollutants, and pesticides. If the "organics all" category was chosen by the questionnaire respondent, the total number of samples that were so reported was arbitrarily divided equally among the three groups. Information on laboratory qualityassurance procedures for each program also was obtained for each of the four major water-quality data-collection categories. 
The inventory includes data-collection activities associated with permit requirements, compliance-and-enforcement regulations, and characterization of ambient water quality. Water-quality analyses resulting from permit-required sampling, by themselves, generally are not considered useful för assessing ambient water quality because they represent effluent water conditions rather than ambient stream or aquifer conditions. However, when used with predictive techniques and in conjunction with instream water-quality data, effluent samples are useful for conducting certain water-quality evaluations. For example, effluent analyses are useful for reach-specific water-quality modelling and waste-load allocation studies and regional and national water-quality assessments to evaluate alternative wastewater treatment technology. Therefore, once identified from the questionnaires, they might have been excluded from further consideration in this study. It was obvious from the questionnaire returns, however, that permit-required programs constitute a major part of the water-quality data-collection programs in each State, and to eliminate them altogether would leave an incomplete view of the current (1984) level of effort in water-quality monitoring. Also, the permit-related programs are needed for comparative cost evaluation. Accordingly, the information about the permit-required programs is included, where required for completeness and comparative purposes, and is excluded from some of the later evaluations, where it would be inappropriate. The inclusion or exclusion of the permitrelated data is indicated for each evaluation step. Permit-related activities were tallied differently from all other activities. The large number of individual permits in each State and the individual sampling requirements stipulated in each permit precluded completing a separate questionnaire for each permit. Instead, a permit program had one questionnaire completed for each type of permit, as required by the permit regulations. For example, two questionnaires were completed in each State for the NPDES permit program, one for municipal-discharge permits and a second for industrial-discharge permits. The accuracy of the information about permit programs varies from program to program and largely depends on the comparability of the sampling requirements contained in each permit. The permit programs most affected by this decreased accuracy, in both States, were the NPDES industrial-permit programs, because each permit's requirements are determined according to the characteristics of the individual discharge.

Organizations contacted as part of the inventory included Federal, State, regional, and local agencies, and academic institutions. Private-sector organizations generally were excluded, mainly because of the proprietary nature of many of the data collected by these organizations, but also because of difficulties in identifying active groups. However, private-sector organizations' sampling activities that were required as part of a waterquality permit program are included in the totals presented here when that total includes permit-required sampling activities. 
Organizations contacted in this inventory were identified by membership in State water organizations, participation in the U.S. Geological Survey's Federal-State cooperative program, participation in the National Water Data Exchange (NAWDEX) program (Cable, 1982), and by State publications. To help ensure consistency between the two States, all municipalities with a population greater than 25,000 were contacted in both States. A number of counties, smaller communities, and quasi-municipal water organizations are included in the local government category with these municipalities in both States. In Ohio, programs undertaking sampling activities in Lake Erie were not included.

Identified program managers were contacted by U.S. Geological Survey personnel by telephone or in person, then the questionnaire was provided to the program manager. Questionnaires were completed for more than 95 percent of the water-quality data-collection programs identified in each State. A list of organizations for which questionnaires were completed and the constituent groups for which they collected data are presented in table 7 for Colorado and in table 8 for Ohio, in the "Supplemental Data" section.

\section{Determination of Water-Quality Data Costs}

An original objective of this phase of the study was to determine the total program costs for the water-quality data-collection programs in the two States. Total program costs might be expected to include the costs for such elements as travel for sampling, shipment of samples, salaries of field or laboratory personnel or both, laboratory analyses, amortization of equipment, administrative overhead, and maintenance of a data file or reporting system or both. The 1984 total program costs were requested in section 1.8 .0 of the questionnaire (see "Supplemental Data" section).

The questionnaire responses, however, did not yield adequate information about total program costs. About one-third of the completed questionnaires lacked any type of cost information. Seventy-five percent of the questionnaires completed in Colorado reported total program costs, which amounted to about $\$ 6$ million. For Ohio, 59 percent of the questionnaires reported total program costs amounting to $\$ 10.7 \mathrm{million}$. Also, the responses that were received were variable in detail. Some included most of the cost elements listed above, while others included only salaries or only laboratory costs.

To provide a more consistent basis for comparing the cost of waterquality data-collection activities, estimates of laboratory expenses were developed. These estimates were based on the number of samples and the types of determinations or analyses reported by the questionnaires.

Charges by the principal U.S. Geological Survey laboratories for determining individual water-quality properties and constituent concentrations, as identified in their 1984 laboratory-services catalog (Feltz and others, 1983), were used as the cost per sample. Those principal laboratories (in Denver and Atlanta) do not perform several of the analyses identified in the questionnaire; therefore, costs for these other analyses were obtained from the U.S. Geological Survey laboratory in Columbus, Ohio. 
In developing the estimated laboratory costs for the reported programs, questionnaire responses for each of the physical property and constituent groups were examined to determine which specific properties and constituents were reported most frequently. The most frequently reported properties and constituents in each group were then used to develop a typical suite of properties and constituents for that group. Because more than one analytical method may be available to measure a property or constituent, the cost of the most commonly used method during the previous 12 months at the U.S. Geological Survey's laboratory in Denver was used. The costs of performing these individual analyses were totaled for each set of properties and constituents. This total was then multiplied by the total number of samples per year reported for that property or constituent group. The result was the estimated yearly laboratory cost for all samples in that property or constituent group. The analyses used for the cost estimates and their associated costs are shown in table 9 in the "Supplemental Data" section.

The U.S. Geological Survey laboratory costs for each of the property and constituent groups were compared to the cost of comparable analyses for a number of other public and private laboratories in both Colorado and Ohio. When all available laboratory costs were compared, U.S. Geological Survey costs were consistently in the middle to lower half of the range of costs.

The laboratory costs for analyzing different properties or constituents varied greatly depending on the specific constituent. For instance, a single pesticide analysis may cost considerably more than several inorganic analyses. The estimated laboratory-costs procedure was used in part to reflect these cost differentials.

Estimating costs of permit-required data-collection programs presented special problems. As previously stated, sampling requirements vary from permit to permit. With more than 6,500 permits, it was impractical to obtain individual sampling requirements, so the most commonly required constituents were assumed for all permits. (Industrial, municipal, strip-mine, and drinking-water permit requirements were calculated separately.)

The laboratory costs constitute only a part, although usually a major part, of the total costs of a water-quality data-collection program. To gain a better insight into the relation between laboratory costs and total program costs, water-quality programs of the U.S. Geological Survey in the two States were examined. These total program costs commonly included most or all of the cost elements listed before.

In Colorado, 22 U.S. Geological Survey programs reported total costs of about $\$ 1.5$ million. Estimated laboratory costs for these programs were $\$ 527,800$ or 35 percent of total program costs. In Ohio, $13 \mathrm{U} . \mathrm{S}$. Geological Survey programs reported total costs of about $\$ 1$ million. Estimated laboratory costs were $\$ 177,500$ or 18 percent of total program costs. For this agency's programs, as with those of other reporting agencies, laboratory costs varied from program to program depending on the number of samples and types of analyses performed. 
Each data base represented by a questionnaire was tested against five broad screening criteria. The purpose of this screening was to provide a preliminary indication of the applicability and availability of the data collected by each program for addressing water-quality questions of regional and national scope. The choice of criteria reflects the potential difficulties involved in combining data from diverse programs in order to develop a water-quality data-base that covers broad geographical areas, as well as the need for reliable water-quality data. The fact that a program's data did not meet these screening criteria does not mean that the data are not useful for meeting that program's objectives or that it could not be used for waterquality studies with objectives different from those stated for this study. The screening criteria selected were:

1. Do the data represent ambient stream or aquifer conditions, as opposed to effluent or treated water?

2. Are the data available for public use?

3. Can the sampling sites be readily located?

4. Is quality-assurance documentation available?

5. Are the data in a computer file?

Criterion 1 was included to identify those water-quality data collected to describe ambient surface- or ground-water conditions. If the questionnaire responses for a constituent group indicated that the station type was a surface- or ground-water sampling station, then those stations met this criterion. Samples collected at a point of effluent discharge or, in the case of ground water, samples representing seepage from a landfill are not useful for defining ambient stream or aquifer conditions; therefore, data from these sites were excluded to avoid an undesirable bias in interpreting general water-quality conditions. Also, samples representing treated drinking water were excluded, while samples collected before treatment were included.

A data base met criterion 2 if the "unrestricted" response to question 7.11 (see "Supplemental Data" section) was chosen. The purpose of this 'study is to evaluate the data collected by public organization; if, for some reason, those data are not readily available to the general public or cannot be published, then they cannot be used for this purpose. Access to data was restricted by organizations for any of several reasons, such as data collected for use in litigation.

Sampling-site locations (criterion 3) were judged adequate if the response to questionnaire question 7.10 indicated that a site's latitude and longitude were known or that the location could be obtained from a map. Sampling sites need to be known well enough to define the part of a stream or aquifer system represented by a sample.

Quality-assurance procedures (criterion 4) are essential to insure the validity and reliability of water-quality data and to help determine comparability of data from different sources. A program met this criterion if the response indicated that any of the quality-assurance options identified in the questionnaire were used in the program. In Phase II, a detailed evaluation of the programs' sample-collection techniques, quality-assurance procedures, and laboratory-analytical methods will be undertaken. 
The fifth criterion, computerized storage of data, was included for practical reasons. A program's data, of course, may be of excellent quality whether or not they are stored in computer files. However, for regional or national assessments, the compilation and manipulation of large volumes of data necessitates that these data be stored in computer files so that the data are readily accessible.

The screening process, using these five criteria, provided a preliminary indication of how many of the existing water-quality data presently collected by a wide variety of organizations are potentially applicable to and readily available for addressing water-quality questions of regional and national scope. In the ensuing evaluation, the data that met criterion 1 (ambient conditions) and 2 (data availability) are presented separately from those that met criteria 3, 4, and 5. A distinction is made between these two sets of criteria to highlight water-quality program elements that might be modified readily in the future to increase the quantity of applicable data. Programs having a mandate to sample effluent or other modified waters, or to keep the data confidential, may not be able to readily change these constraints and, therefore, have little possibility of contributing to the broader data base in the future. Conversely, water-quality data-collection programs that did not have adequate site locations, adequate quality-assurance procedures, or did not computerize their data possibly could do so in the future, thereby increasing the quantity of data applicable to and available for regional or national assessments.

\section{ORGANIZATIONS COLLECTING WATER-QUALITY DATA}

Water-quality data are collected by a wide variety of organizations representing all levels of government, academic institutions, and the private sector. Each organization may conduct several different types of datacollection programs to meet various responsibilities or mandates. These may include water-quality regulation, pollution control, planning, research, policy making, and resource assessment. The variety of purposes for which water-quality data are used also results in a wide variety of types and amounts of data that are collected. The number of programs, therefore, does not totally reflect an organization's degree of effort. The degree of effort associated with each program is defined herein as a function of the number of data-collection sites and the number of samples collected per year at each site. This section summarizes the number of organizations collecting waterquality data, and their degree of effort, in Colorado and Ohio during 1984.

\section{Colorado}

More than 150 organizations in Colorado were contacted as part of this inventory. Forty-eight of these organizations conducted 115 water-quality data-collection programs during 1984 (table 1). Federal government agencies were responsible for 50 percent of all identified active water-quality datacollection programs. Local agencies were responsible for the second largest number of programs (26 percent). State agencies were responsible for 15 percent of all programs. Regional (interstate) agencies and academic institutions were responsible for 9 percent of the programs. 
Table 1.--Numbers of organizations reporting water-quality data-collection programs and numbers of programs reported, Colorado, $1984^{1}$

Source of data

Number of

organizations

reporting programs
Total

number of

programs

Federal: U.S. Geological Survey.

Other Department of the

Interior agencies.

U.S. Environmental

Protection Agency.

Other Federal agencies.

Total, Federal agencies.
1

4

1

3

6

$12 \quad 58$

18

State: Colorado Department of

1 Health.

13

Other State agencies.

Total, State agencies.

\begin{tabular}{lr}
2 & 4 \\
\hline 3 & 17
\end{tabular}

Regional: Total, regional agencies.

3

$3-120$
-120

(Intrastate)

Local: Total, local agencies.

27

30

Academic institutions .

3

4

Total, all organizations.

48

115

${ }^{1}$ Permit-required programs are included under the heading for the organization responsible for their implementation. 
Organizations in Colorado with water-quality data-collection programs are listed in table 7 ("Supplemental Data" section). At the Federal level, datacollection activities are divided among 12 different agencies. The Department of the Interior had the largest number of agencies (5) collecting waterquality data. The Colorado Department of Health was the principal State agency collecting water-quality data.

The percentage of samples, both surface and ground water, reported by each level of government and by academic institutions for Colorado is summarized in figure 2. Although Federal agencies had the largest number of programs, they reported only 24 percent of the samples. State agencies reported the greatest number of samples (40 percent). This large number of samples reported by the State agencies is an indication of the variety of programs they must maintain and the fact that their responsibilities are statewide.

\section{Ohio}

More than 200 organizations, including Federal, State, regional, county, and municipal agencies, and academic institutions, were contacted in Ohio. Forty-two of these organizations conducted active water-quality datacollection programs during 1984 (table 2), accounting for 88 individual programs. Programs associated with data-collection activities for Lake Erie were not included in this study.

Federal, State, and local agencies had similar numbers of water-quality data-collection programs, and together, they were responsible for 88 percent of the total programs. Academic institutions and regional agencies were responsible for the remaining 12 percent of the programs. The Ohio Environmental Protection Agency, with 17 programs, had the largest number of programs for an individual organization, followed by the U.S. Geological Survey with 13 programs. The water-quality data-collection programs undertaken by the different organizations are listed in table 8 ("Supplemental Data" section).

The percentage of samples, both surface and ground water, collected by each organizational category is summarized in figure 2 . Local agencies reported the largest number of samples, 58 percent, followed by State agencies, 26 percent. The large number of samples reported by local agencies results primarily from the monitoring of sources of untreated drinking water. Although Federal agencies accounted for the largest number of programs, they account for only 7 percent of the samples reported. The difference between the number of programs and number of samples reported by the different levels of governments results from differences in program objectives and the numbers of sampling sites and sampling frequencies required to meet those objectives. For example, the objectives of local agency programs may require that samples be collected daily; whereas, the objectives of Federal programs may require that samples be collected weekly or monthly. 


\section{A. Colorado}

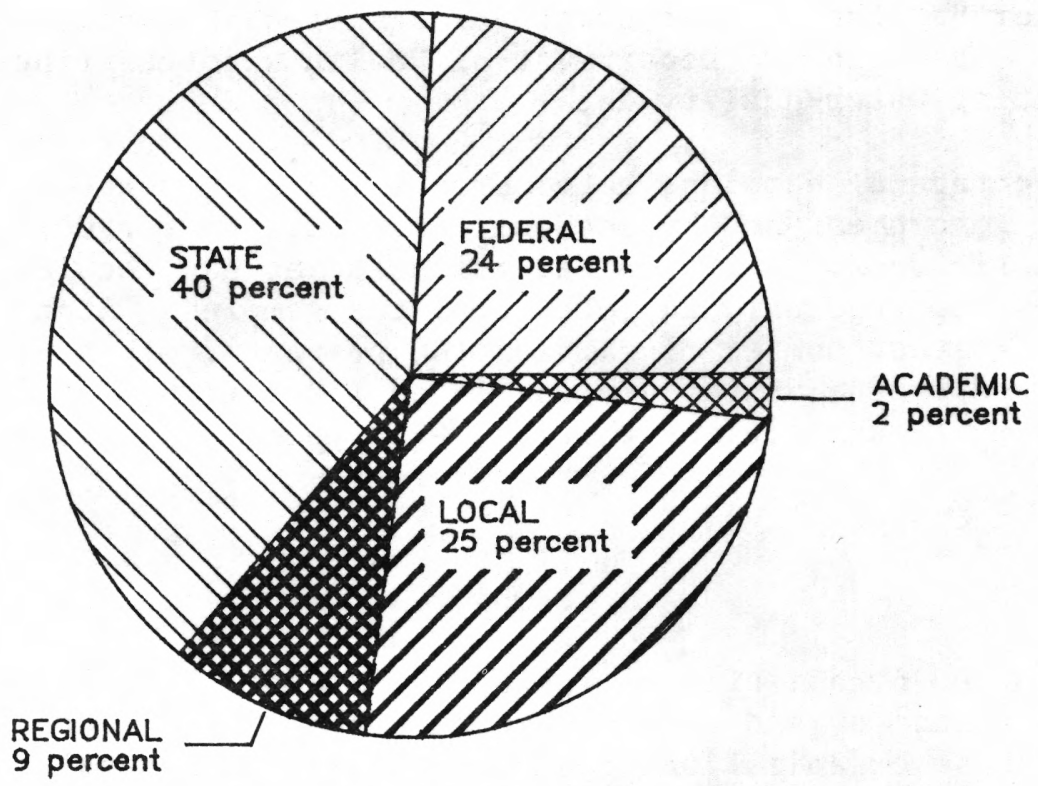

Total samples $=182,470$

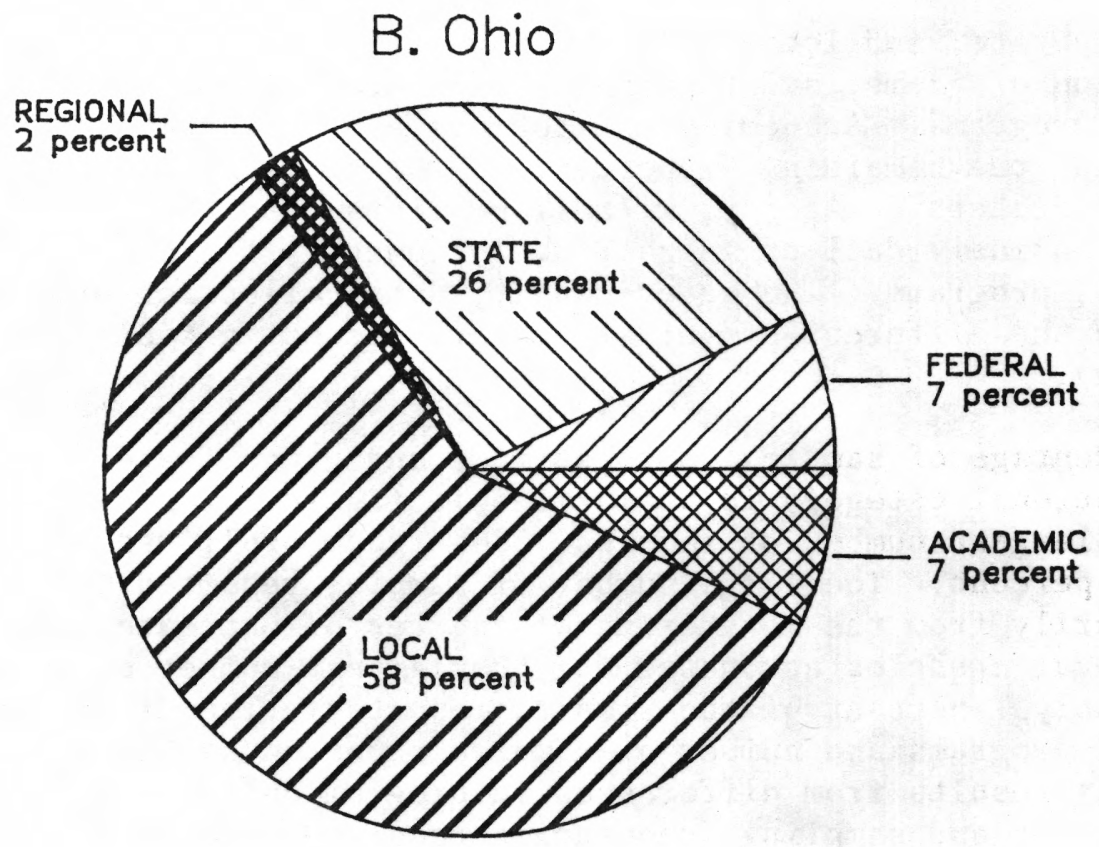

Total samples $=192,560$

Figure 2.--Distribution of water-quality samples reported during 1984 by organizational category: (A) Colorado, and (B) Ohio (samples collected to meet permit requirements not included). 
Table 2.--Numbers of organizations reporting water-quality data-collection programs and numbers of programs reported, Ohio, $1984^{1}$

Source of data
Number of

organizations reporting programs
Tota1

number of programs

Federal: U.S. Geological Survey.

U.S. Environmental

Protection Agency.

Other Federal agencies.

Total, Federal agencies.

Interior agencies.
Regional: Total, regional agencies.

(Interstate)
1

2

1

2

13

2

2

11

\begin{tabular}{ll}
5 & 11 \\
\hline 9 & 28
\end{tabular}

State: Ohio Environmental

1

17

Protection Agency.

Other State agencies.

$3 \quad 5$

Total, State agencies.

4

22

Local: Total, local agencies.

22

27

Academic institutions.

6

8

Total, all organizations.

42

88

${ }^{1}$ Permit-required programs are included under the heading for the organization responsible for their implementation. 
The primary difference in the total number of programs between the two States is the number of Federal programs: 58 are conducted in Colorado; 28 in Ohio. The larger number of Federal programs in Colorado results from the larger Federal land ownership in that State and the management responsibilities associated with this ownership.

In both States, the most active single organization is a State agency: the Colorado Department of Health (38 percent of all samples) in Colorado, and the Ohio Environmental Protection Agency (19 percent of all samples) in Ohio. These two organizations have similar responsibilities as the principal waterquality-management agencies in their respective States.

In both States, the U.S. Geological Survey had more programs and reported more samples than any other Federal agency. The U.S. Environmental Protection Agency had very few active water-quality data-collection programs in either Colorado or Ohio. The U.S. Environmental Protection Agency oversees waterquality data-collection activities in these States and is responsible for reviewing and approving State water-quality-management activities. 
Water-quality data, as mentioned previously, was collected for a variety of reasons. The purpose determines where samples were collected, frequency of collection, the methods used, and for which properties and constituents the samples were analyzed. These characteristics, in turn, can affect the applicability and availability of the data for broad-scale studies. For this report, we have identified three general categories: (1) Required by permit, (2) required for compliance-and-enforcement activities, and (3) to characterize ambient water-quality conditions.

\section{Colorado}

More than 339,000 water-quality samples were reported in Colorado during 1984. The distribution of samples reported in each of the three purpose categories is shown in figure 3. Most of the samples reported in Colorado were either required by permit ( 46 percent) or collected to characterize ambient water-quality conditions ( 42 percent). Ninety percent of al1 samples were surface-water samples. Most of the permit samples were collected by municipal and industrial wastewater dischargers to meet NPDES requirements under the Clean Water Act of 1977 (about 1,100 permits) and by drinking-water suppliers to meet the requirements of the Safe Drinking Water Act of 1974 (about 1,650 permits). 


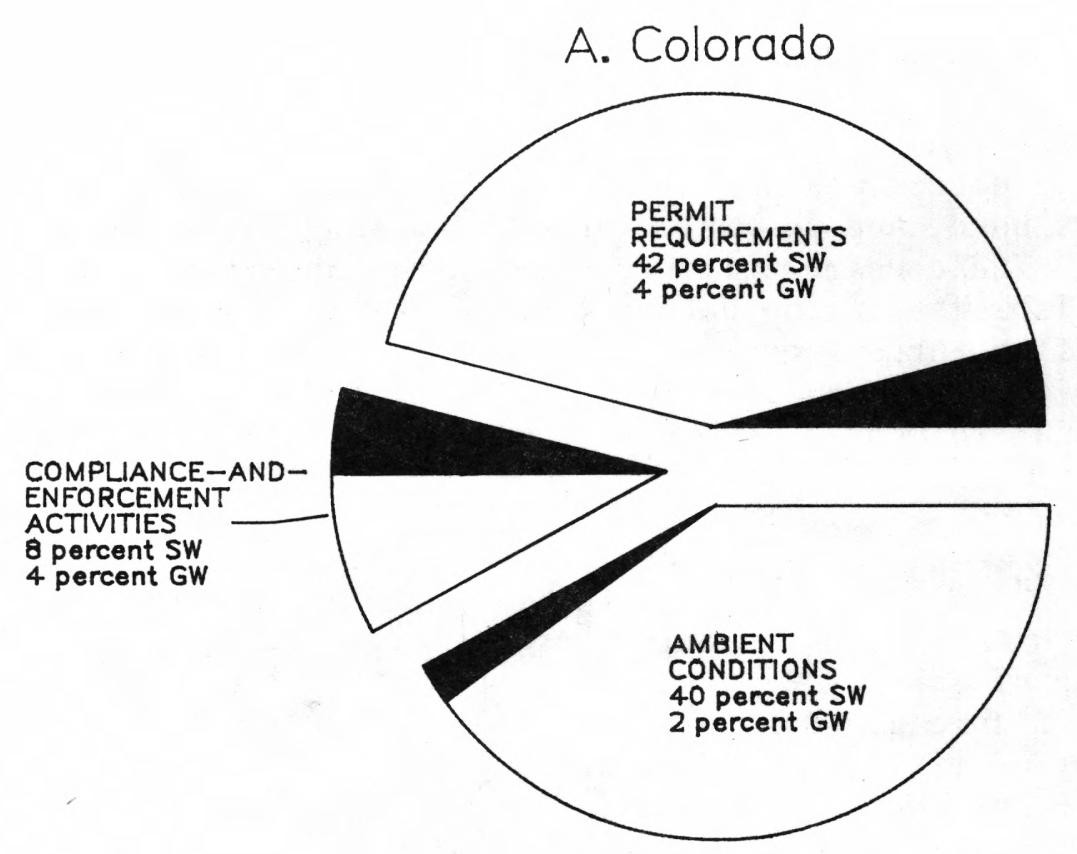

Total samples $=339,200$

B. Ohio

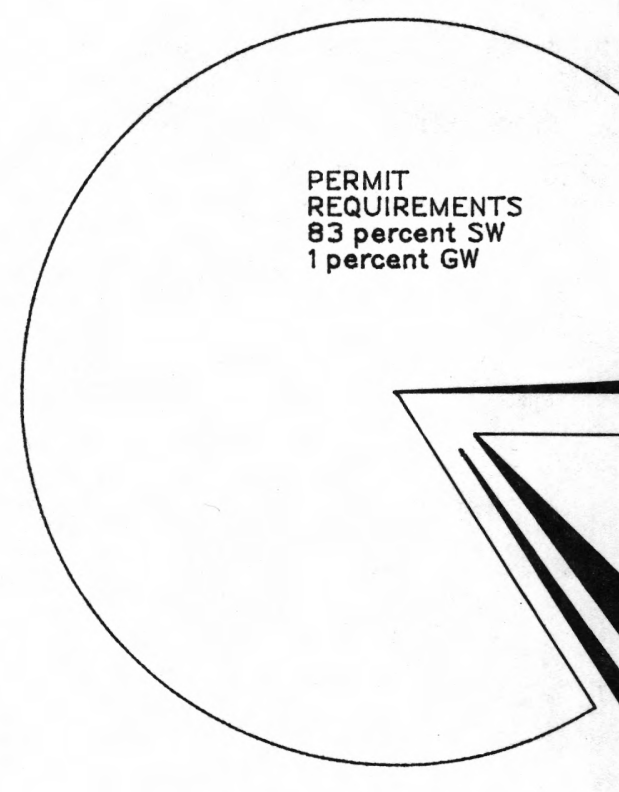

Total samples $=1,197,530$
COMPLIANCE-ANDENFORCEMENT ACTIVITIES 0.3 percent $S W$

0.7 percent GW

\section{EXPLANATION}

\section{SURFACE-WATER (SW)}

GROUND-WATER (GW)

Figure 3.--Percentages of samples reported during 1984 for the purpose of meeting permit requirements, undertaking compliance-and-enforcement activities, or characterizing ambient conditions: (A) Colorado, and (B) Ohio. 
About 1,200,000 water-quality samples were collected in Ohio during 1984. The distribution of samples reported in Ohio for each of the three purposes are shown in figure 3. Most samples, 84 percent, were reported to meet permit requirements. There were more than 3,800 active permits in Ohio during 1984, including 1,139 wastewater-discharge permits for industries, 932 for municipalities, 235 for strip mines; as well as 1,550 for public drinking-water supplies. Many permit holders are required to collect samples daily, which accounts for the large number of samples in the permit-required category. Almost all the samples in the permit category were surface water. Fifteen percent of the samples were for characterizing ambient conditions (12 percent surface; 3 percent ground water). One percent of all samples were for compliance-and-enforcement activities; most of these were ground-water samples.

\section{Comparison Between States}

The number of samples reported for each purpose in Colorado and Ohio is compared in figure 4. Nearly four times as many samples were reported during 1984 in Ohio as in Colorado. Because of its greater industrial activity, Ohio has about 30 percent more NPDES permits than does Colorado and, therefore, a much larger number of permit-required samples. Also, even though Colorado and Ohio have about equal numbers of drinking-water permits, the permits in Ohio require more frequent sampling than those in Colorado, which further increases the number of permit samples reported in Ohio. The numbers of samples reported for characterizing ambient water-quality conditions are similar in Colorado and Ohio; however, these samples represent 42 percent of all samples reported in Colorado and only 15 percent in Ohio.

In both States, relatively few samples--less than 10 percent--were collected from ground-water. This may be due, in part, to the fact that ground water moves very slowly in comparison to surface water; thus, groundwater quality is less likely to change as rapidly as surface-water quality. The difference in sample numbers is also a reflection of the greater usage of surface water in both States. Of the total reported samples, about 26,000 more ground-water samples were collected in Ohio than in Colorado. 


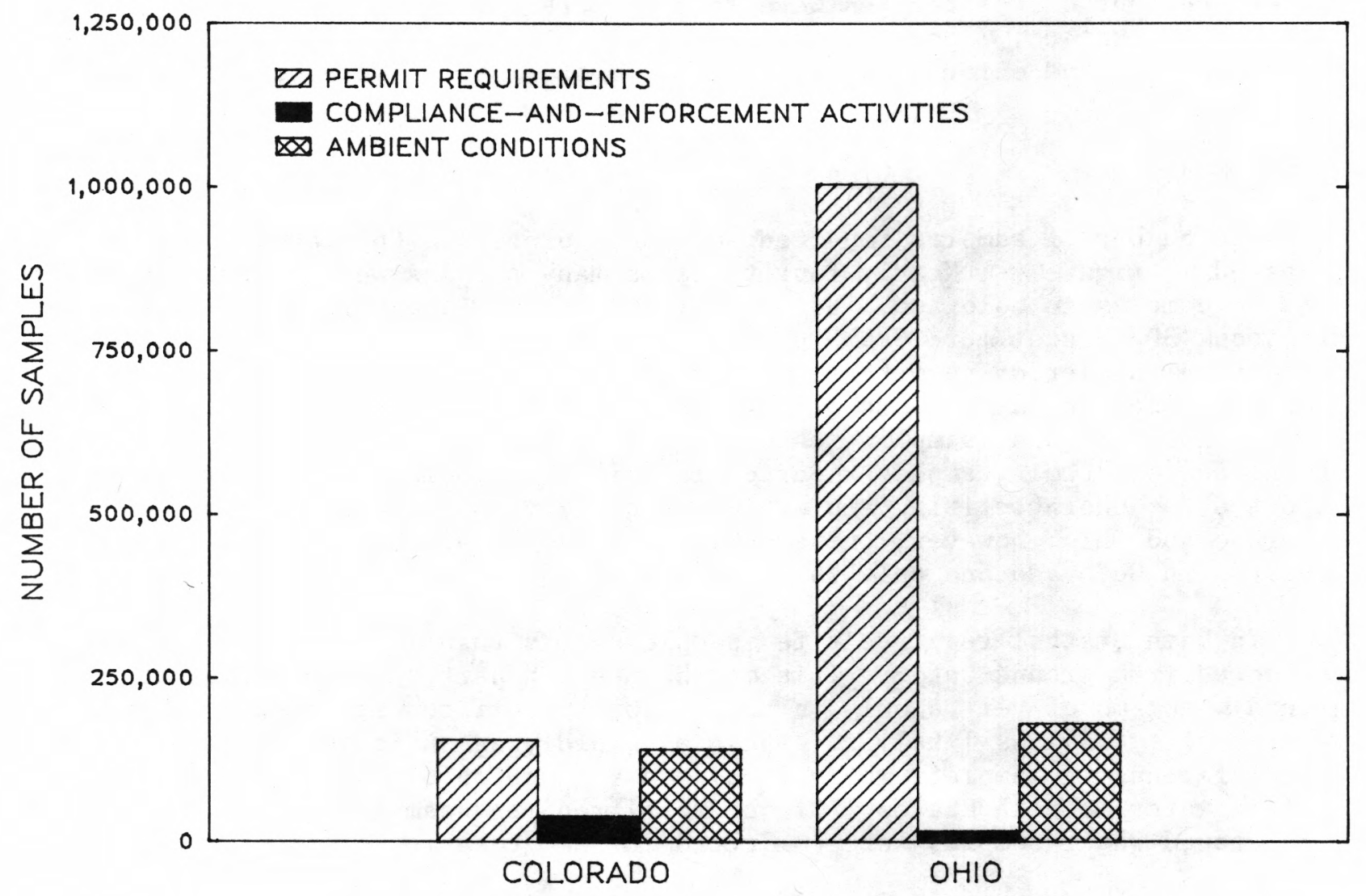

Figure 4.--Comparison of the numbers of water-quality samples reported for the purposes of meeting permit requirements, undertaking complianceand-enforcement activities, or characterizing ambient conditions in Colorado and Ohio, 1984. 
Individual water samples can be analyzed for a variety of specific physical properties and chemical constituents. Different properties and constituents address different problems and have differing costs. For the purpose of this report, these properties and constituents have been categorized into 11 major groups, as described in the section entitled "Methods of Acquiring, Compiling, and Evaluating Information." In addition to these 11 groups, samples also were reported for chemical analysis of sediment and chemical analysis of fish tissue. Although both of these types of data can be useful for interpreting and understanding water quality, the number of these samples reported in both States was very small, and these data are not included in the following compilations.

\section{Colorado}

The number of samples analyzed for each of the property and constituent groups in Colorado during 1984 is shown in figure 5 for surface water and in figure 6 for ground water. Samples collected for compliance-and-enforcement activities and for characterizing ambient conditions have been grouped together in these figures. For surface water, the physical-properties group had the largest number of samples for all three of the purpose categories. The inorganic constituent group was second. Less than 1 percent of all surface-water samples were collected for the analysis of specific organic compounds as represented by the priority-pollutants and pesticides groups.

The physical-properties and inorganic-constituents groups also were the two largest groups among ground-water samples collected for compliance-andenforcement and characterizing ambient conditions activities (fig. 6). Permit-required ground-water samples, however, show a distinctly different distribution. The biota and organic substances constituent groups were first and second in number of permit-required samples. In contrast to surface-water samples, 12 percent of all ground-water samples were collected for analysis of specific organic compounds represented by priority pollutants and pesticides. (Note that the two graphs are not directly comparable because of the difference in vertical scale.)

Physical properties such as temperature, $\mathrm{pH}$, and specific conductance are the least costly analyses, and the resulting data can provide a good preliminary indication of water-quality conditions. Also, automated monitoring equipment enables more frequent measurement of properties such as $\mathrm{pH}$ and specific conductance, which greatly increases the total number of these measurements. In contrast, priority pollutants and pesticides were sampled less frequently, largely because of the relatively high cost of these analyses. 

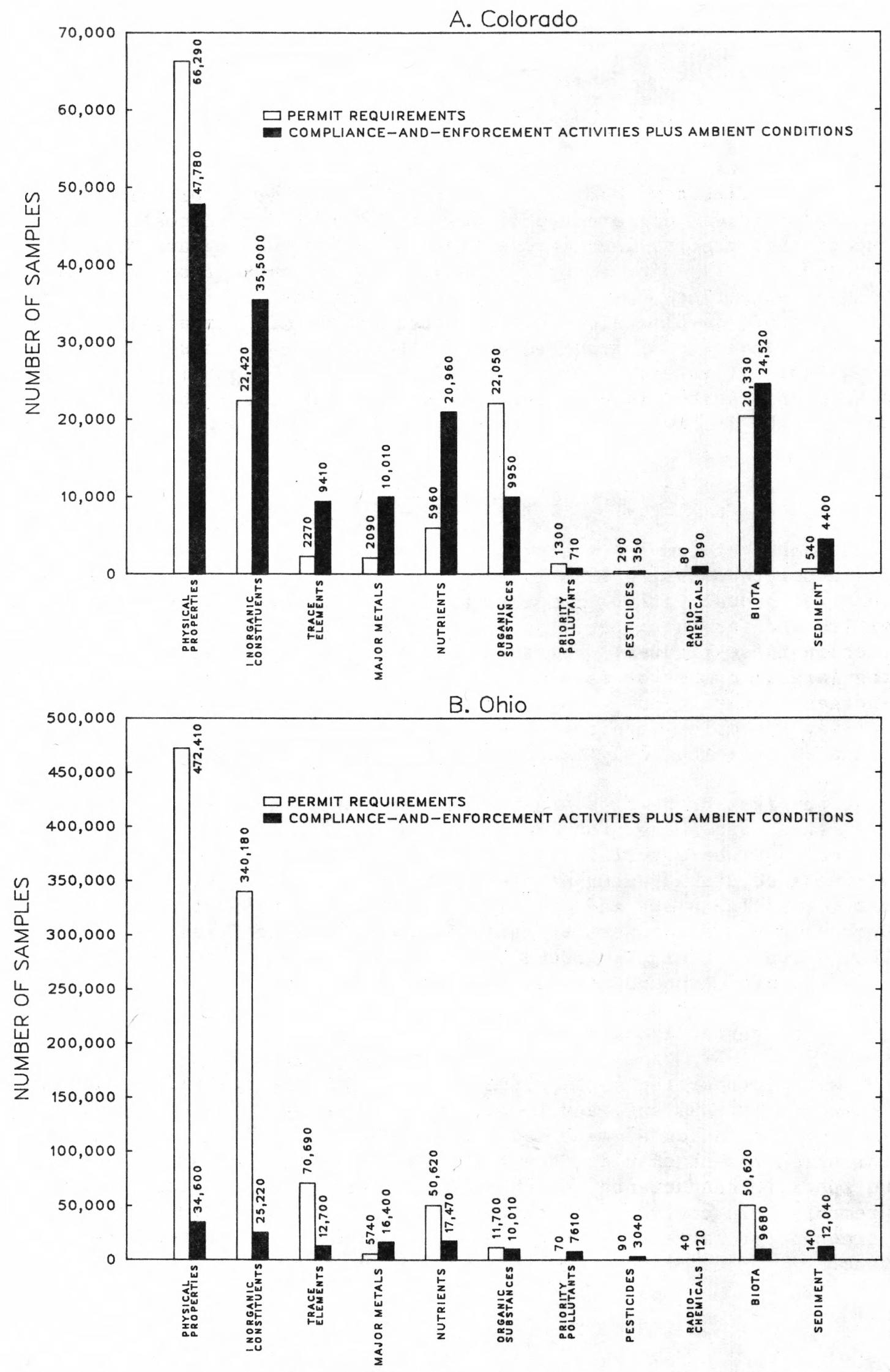

Figure 5.--Number of surface-water samples reported during 1984 by major property and constituent groups: (A) Colorado, and (B) Ohio. (See glossary for explanation of constituent groups.) 

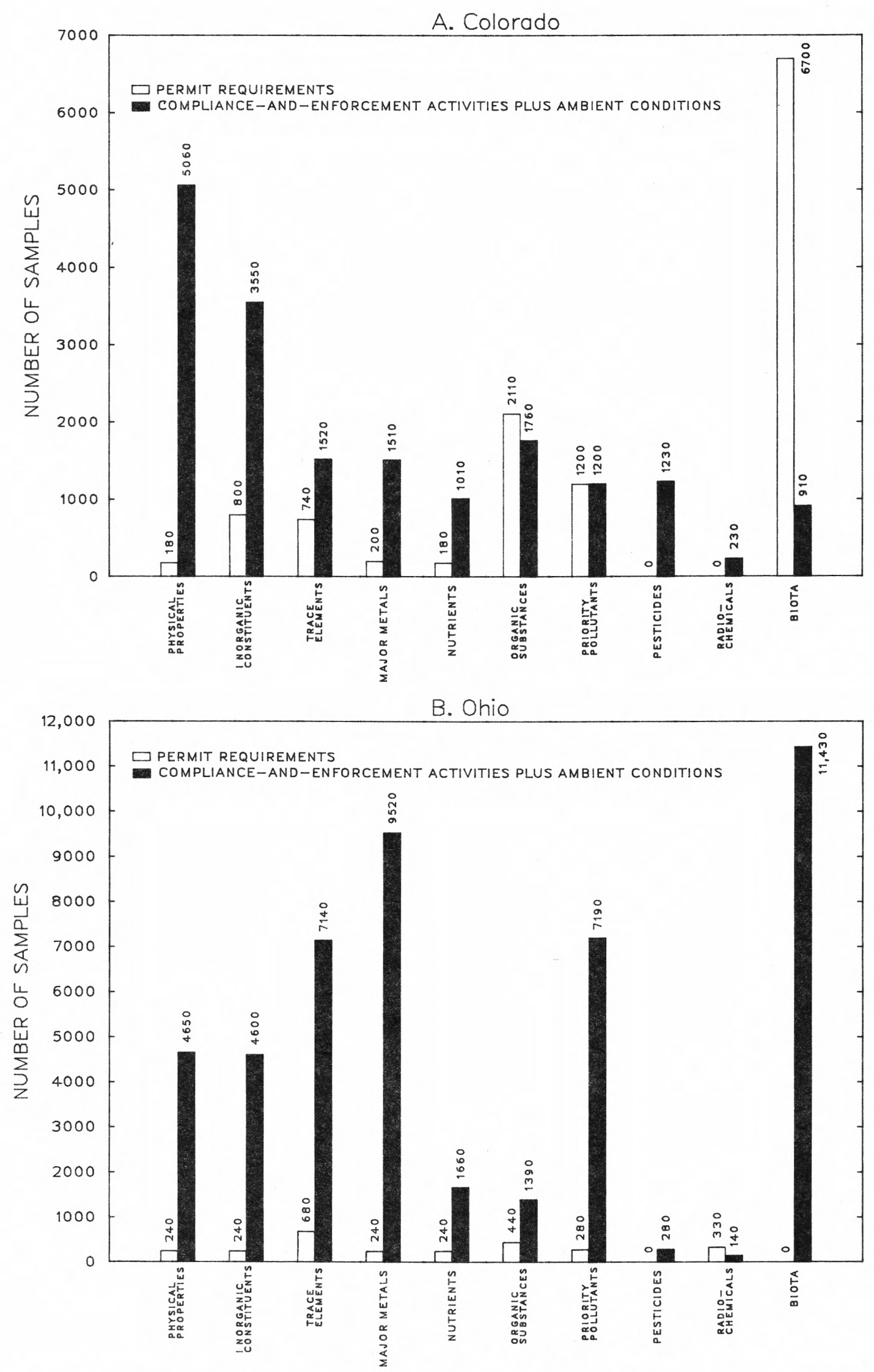

Figure 6.--Number of ground-water samples reported during 1984 by major property and constituent groups: (A) Colorado, and (B) Ohio. (See glossary for explanation of constituent groups.) 
The number of samples analyzed for each of the property and constituent groups in Ohio during 1984 is summarized in figure 5 for surface water and in figure 6 for ground water (note difference in vertical scales). The largest number of surface-water samples analyzed in both categories were for physical properties (47 percent of permit-required and 24 percent of compliance-andenforcement plus ambient-condition samples). For ground water, the largest number of analyses for permit-required samples was trace elements

(25 percent), while the largest number of analyses for compliance-andenforcement plus ambient-condition samples was biota ( 24 percent)--mostly bacteriological determinations in untreated drinking-water supplies.

\section{Comparison Between States}

The number of samples reported in Colorado and Ohio by major property and constituent groups are compared in figure 7. (Samples collected to meet permit requirements are not included.) The physical-properties constituent group had the largest number of samples in both States: 29 percent in Colorado and 20 percent in Ohio. Priority pollutants and pesticides represented only 1 percent of all samples collected in Colorado and 9 percent in Ohio. However, these groups represented 12 percent of the ground-water samples in Colorado and 16 percent in Ohio. The greater emphasis on these constituents in ground water than in surface water is the result of the increasing concern about ground-water pollution by potentially toxic substances and because adequate monitoring of ground water can be accomplished with relatively infrequent sampling. 
More samples were analyzed for radiochemical constituents in Colorado than in Ohio, a reflection of the uranium mining in Colorado. Conversely, in Ohio more samples were analyzed for trace elements, major metals, and priority pollutants than in Colorado, a reflection of the greater industrial activity that may comprise sources of these constituents in Ohio.

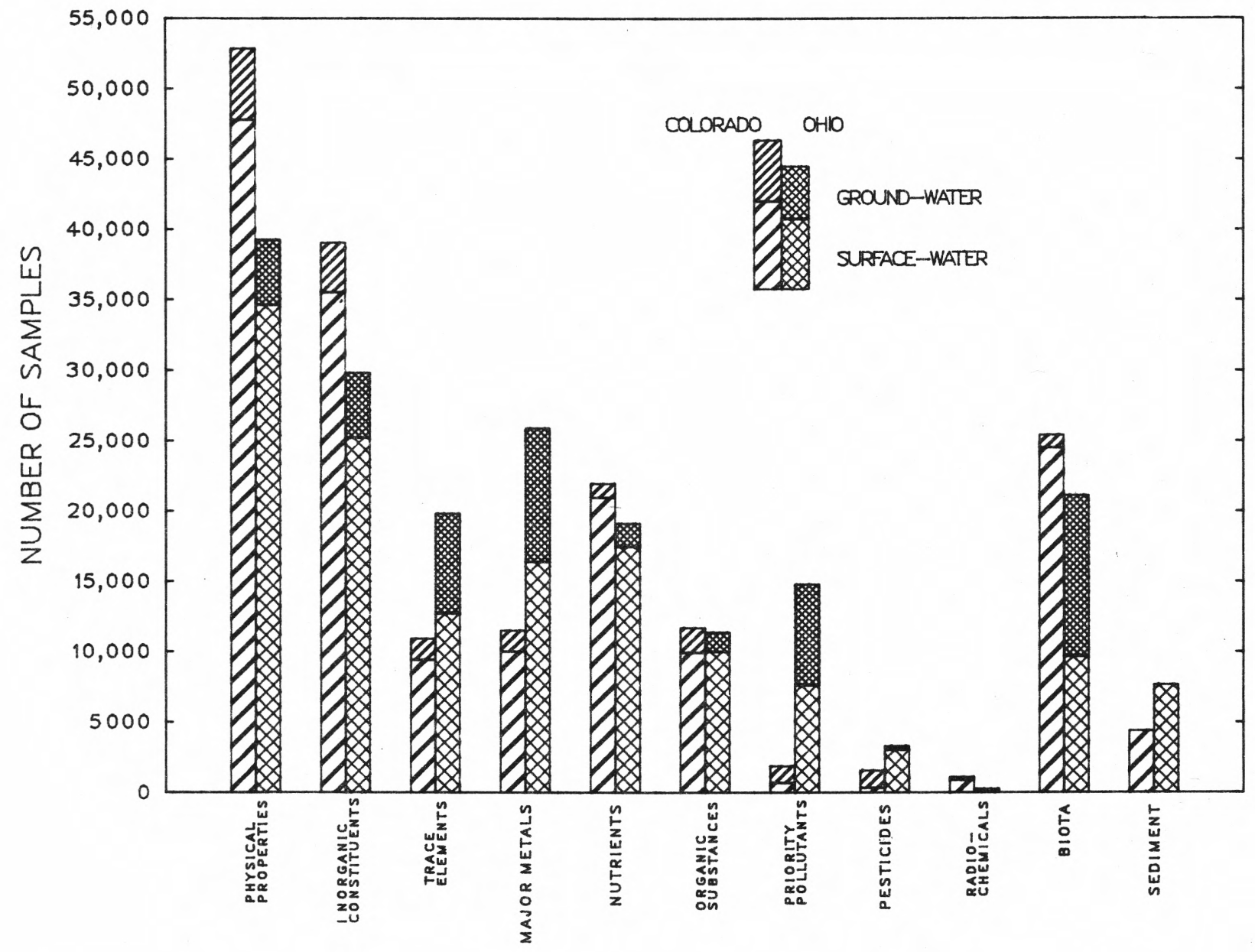

Figure 7.--Numbers of surface- and ground-water samples by major property and constituent groups, Colorado and Ohio, 1984. (Samples reported to meet permit requirements are not included.) 
Estimated laboratory costs were developed to provide a more consistent basis for comparing the cost of data-collection activities for different organizations and constituent groups (see section entitled "Methods of Acquiring, Compiling, and Evaluating Information"). Estimated laboratory costs were developed for the samples collected in the three purpose categories described previously: permit-required, compliance-and-enforcement activities, and ambient conditions. Cost estimates are presented by the organization collecting the samples and expending the funds, as opposed to the source of the funds. For example, a local data-collection agency that receives some of its funding from Federal sources is listed as the program agency, rather than the Federal agency supplying the funds.

\section{Colorado}

Estimated laboratory costs for the different purposes of data collection are shown in figure 8 . The total estimated cost of all sample analyses, including permit-required sampling for 1984 , was more than $\$ 13.4$ million. The distribution of these costs is similar to the percentage of samples reported for each purpose (fig. 3) with the estimated cost of analyzing the ambientcondition samples nearly equal to that of the permit-required samples. Permit-required samples represented the largest percentage of estimated laboratory costs- -45 percent. Ambient-condition samples were second with 38 percent of the costs. Samples reported for compliance-and-enforcement activities represented 17 percent of the estimated laboratory costs.

Estimated laboratory costs are shown by organizational category in table 3. The distribution of total expenditures among the organizational categories is not significantly different from the distribution of the sample totals discussed earlier. State agencies had the largest total expenditures, followed closely by Federal and local agencies. The estimated laboratory costs, as shown in table 3 for the analyses of surface-water samples and ground-water samples, also reflect the level of activity by each organizational category. State agencies, which reported the largest number of surface-water samples, had the largest surface-water-related expenditures, and Federal agencies, which reported the largest number of ground-water samples, had the largest ground-water-related expenditures.

The distribution of expenditures between organizational categories and surface and ground water is largely a function of organizational responsibilities. Federal agencies at the time of the inventory still had most of the responsibility for identifying and monitoring toxic-waste sites, including Federal facilities. This resulted in the large proportion of Federal ground-water expenditures. 

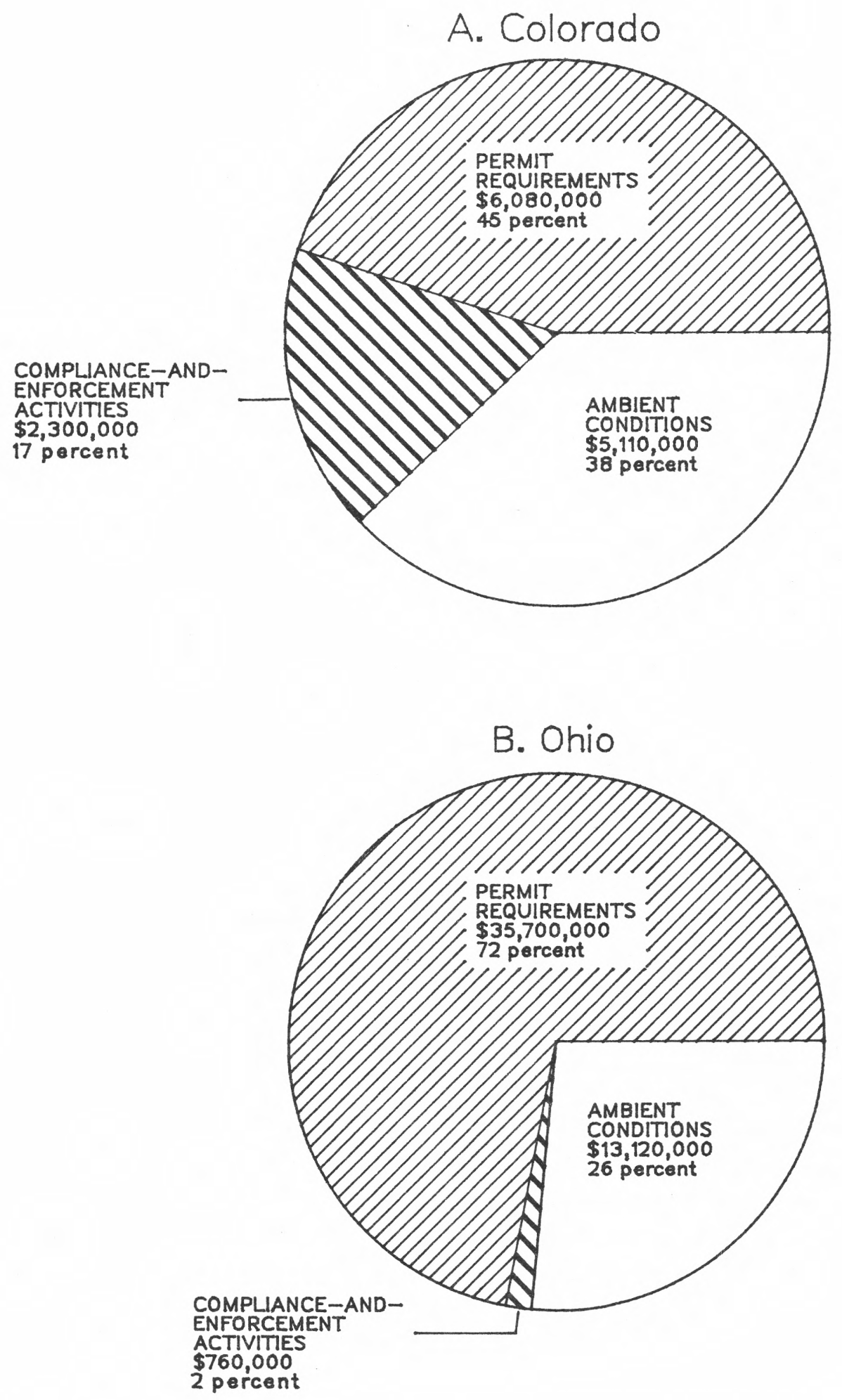

Figure 8.--Percentages of estimated laboratory costs for the purposes of meeting permit requirements, undertaking compliance-and-enforcement activities, or characterizing ambient conditions during 1984:

(A) Colorado, and (B) Ohio. Estimates based on U.S. Geological Survey laboratory costs. 
Table 3.--Summary of estimated laboratory costs by organizational category, Colorado, 1984

$$
[<\text {, less than }]
$$

\begin{tabular}{|c|c|c|c|}
\hline \multirow[b]{2}{*}{ Organizational category ${ }^{1}$} & \multicolumn{3}{|c|}{$\begin{array}{l}\text { Estimated }{ }^{2} \text { cost in thousands of dollars } \\
\text { and percentages }{ }^{3} \text { (in parenthesis) }\end{array}$} \\
\hline & Total & $\begin{array}{l}\text { Surface } \\
\text { water }\end{array}$ & $\begin{array}{l}\text { Ground } \\
\text { water }\end{array}$ \\
\hline Federal & $\begin{array}{r}2,182 \\
(16)\end{array}$ & $\begin{array}{l}912 \\
(8)\end{array}$ & $\begin{array}{r}1,270 \\
(53)\end{array}$ \\
\hline State & $\begin{array}{r}2,794 \\
(21)\end{array}$ & $\begin{array}{r}2,771 \\
(25)\end{array}$ & $\begin{array}{r}23 \\
(1)\end{array}$ \\
\hline Regional & $\begin{array}{l}495 \\
(4)\end{array}$ & $\begin{array}{l}495 \\
(5)\end{array}$ & $\begin{array}{r}0 \\
(0)\end{array}$ \\
\hline Local & $\begin{array}{r}1,828 \\
(13)\end{array}$ & $\begin{array}{r}1,670 \\
(15)\end{array}$ & $\begin{array}{l}158 \\
(7)\end{array}$ \\
\hline Academic & $\begin{array}{l}107 \\
(1)\end{array}$ & $\begin{array}{l}101 \\
(1)\end{array}$ & $(<1)^{6}$ \\
\hline Subtotals, all organizations. & $\begin{array}{r}7,406 \\
(55)\end{array}$ & $\begin{array}{r}5,949 \\
(54)\end{array}$ & $\begin{array}{r}1,457 \\
(61)\end{array}$ \\
\hline Subtotals, permit-required ${ }^{4}$ & $\begin{array}{r}6,078 \\
(45)\end{array}$ & $\begin{array}{r}5,159 \\
(46)\end{array}$ & $\begin{array}{r}919 \\
(39)\end{array}$ \\
\hline Totals ${ }^{3}$ (rounded) & 13,480 & 11,110 & 2,380 \\
\hline
\end{tabular}

${ }^{1}$ Cost breakdown by agency group is for samples collected for compliance-and-enforcement activities and for ambient-conditions purposes.

${ }^{2}$ Estimates based on 1984 U.S. Geological Survey laboratory costs.

${ }^{3}$ Percentages of totals shown below in same column.

${ }^{4}$ Information is inadequate to distribute permit-required laboratory costs among agency groups; however, most are incurred by local agencies and private organizations. 
Estimated laboratory costs for each property and constituent group for both surface and ground water are shown in figure 9 (permit-required samples not included). For surface-water analyses, inorganic constituents had the greatest estimated costs. The physical-properties group, with the largest number of samples ( 30 percent), accounted for only 11 percent of total surface-water expenditures because measurements of these properties are relatively inexpensive to obtain. Although the cost per sample to analyze for organic compounds, such as priority pollutants, is expensive, estimated 1984 expenditures are small because of the relatively fewer number of samples collected for these analyses.

In contrast to surface water, the largest estimated laboratory costs for ground-water samples were for priority pollutants and pesticides, comprising 14 percent of the samples and 59 percent of the total estimated costs. These expenditures can be attributed principally to sampling undertaken by Federal agencies to monitor for hazardous wastes.

\section{Ohio}

The total estimated laboratory cost of all sample analyses for surface and ground water during 1984 was about $\$ 50$ million. The distribution of these costs for sampling to meet permit requirements, undertake compliance-andenforcement activities, and characterize ambient water-quality conditions is shown in figure 8. Based on these estimates, 72 percent of total laboratory costs were spent on permit requirements, 2 percent on compliance-andenforcement activities, and 26 percent on characterizing ambient conditions.

For Ohio, estimated laboratory expenditures by organizational category, for both surface and ground water, are summarized in table 4. Excluding permit-required samples, estimated costs were greatest for local agencies for both surface- and ground-water samples, reflecting the large number of samples collected by local agencies for monitoring drinking-water supplies. Estimated costs for surface and ground water were similar for local agencies; however, for Federal, State, and regional agencies and academic institutions, estimated costs were highest for surface water, reflecting the larger proportion of surface-water samples collected by the agencies. 

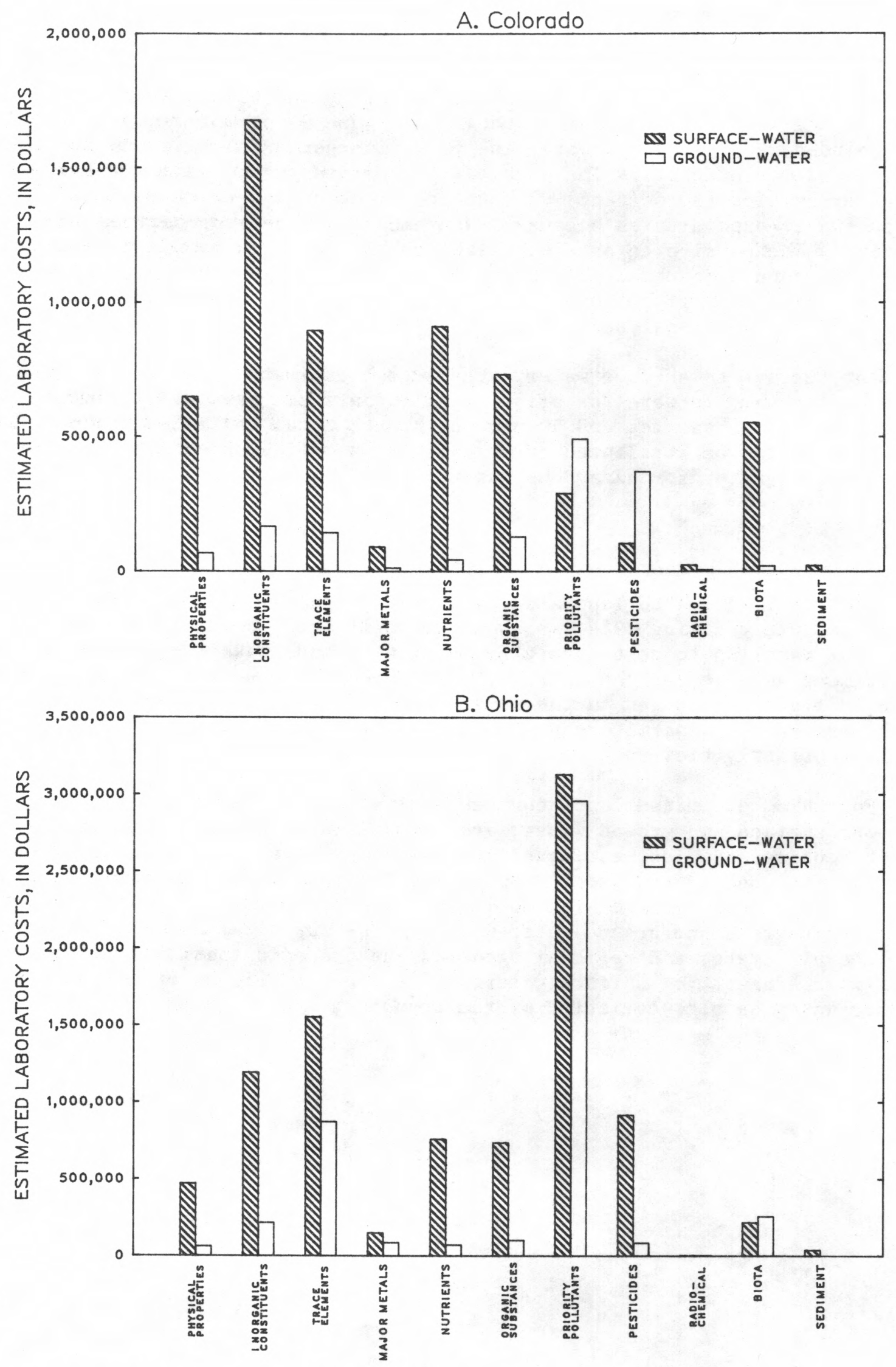

Figure 9.--Estimated costs for laboratory analysis of surface- and groundwater samples, by property and constituent group, 1984: (A) Colorado, and (B) Ohio. (Samples reported to meet permit requirements are not included. Estimates are based on 1984 U.S. Geological Survey laboratory costs.) 
Table 4.--Summary of estimated laboratory costs by organizational category, Ohio, 1984

$$
[<, \text { less than }]
$$

\begin{tabular}{|c|c|c|c|}
\hline \multirow[b]{2}{*}{ Organizational category ${ }^{3}$} & \multicolumn{3}{|c|}{$\begin{array}{l}\text { Estimated }{ }^{1} \text { cost in thousands of dollars } \\
\text { and percentages }{ }^{2} \text { (in parenthesis) }\end{array}$} \\
\hline & Total & $\begin{array}{l}\text { Surface } \\
\text { water }\end{array}$ & $\begin{array}{l}\text { Ground } \\
\text { water }\end{array}$ \\
\hline Federal & $\begin{array}{l}353 \\
(1)\end{array}$ & $\begin{array}{l}291 \\
(1)\end{array}$ & $\begin{array}{r}62 \\
(1)\end{array}$ \\
\hline State & $\begin{array}{r}2,561 \\
(5)\end{array}$ & $\begin{array}{r}1,998 \\
(4)\end{array}$ & $\begin{array}{r}562 \\
(11)\end{array}$ \\
\hline Regional & $\begin{array}{l}385 \\
(1)\end{array}$ & $\begin{array}{l}385 \\
(1)\end{array}$ & $\begin{array}{r}0 \\
(0)\end{array}$ \\
\hline Local & $\begin{array}{r}9,494 \\
(19)\end{array}$ & $\begin{array}{r}5,407 \\
(12)\end{array}$ & $\begin{array}{r}4,088 \\
(82)\end{array}$ \\
\hline Academic & $\begin{array}{r}1,090 \\
(2)\end{array}$ & $\begin{array}{r}1,084 \\
(2)\end{array}$ & $\begin{array}{r}7 \\
(<1)\end{array}$ \\
\hline Subtotals, all organizations. & $\begin{array}{r}13,883 \\
(28)\end{array}$ & $\begin{array}{r}9,165 \\
(20)\end{array}$ & $\begin{array}{r}4,719 \\
(95)\end{array}$ \\
\hline Subtotals, permit-required ${ }^{4}$. & $\begin{array}{r}35,700 \\
(72)\end{array}$ & $\begin{array}{r}35,432 \\
(80)\end{array}$ & $\begin{array}{l}268 \\
(5)\end{array}$ \\
\hline Totals ${ }^{3}$ (rounded) & 49,580 & 44,600 & 4,990 \\
\hline
\end{tabular}

${ }^{1}$ Cost breakdown by agency group is for samples collected for compliance-and-enforcement activities and for ambient-conditions purposes.

${ }^{2}$ Estimates based on 1984 U.S. Geological Survey laboratory costs.

${ }^{3}$ Percentages of totals shown below in same column.

${ }^{4}$ Information is inadequate to distribute permit-required laboratory costs among agency groups; however, most are incurred by local agencies and private organizations. 
Estimated laboratory costs for compliance-and-enforcement activities and characterizing ambient conditions (permit-required samples excluded) for each major property and constituent group during 1984 are summarized in figure 9. For surface water, the greatest costs, 34 percent, were for analyses of priority pollutants, although this group represents only 5 percent of the total number of samples. This results from the large cost (more than $\$ 400$ per sample) of priority-pollutants analyses. Similarly, 63 percent of the estimated total laboratory costs for ground-water sample analyses were spent on the priority-pollutants group, although this group only represents 15 percent of the total ground-water samples. In contrast, biota (mainly bacteriologica1), representing 24 percent of the total number of samples, accounted for only 5 percent of the total estimated costs because of their low unit costs.

\section{Comparison Between States}

Total estimated laboratory costs of all samples collected in Colorado and Ohio during 1984 was about $\$ 63$ million. Estimated expenditures were higher in Ohio than in Colorado because of the larger number of samples collected in Ohio. Samples collected to meet permit requirements represented the largest percentage of the total estimated laboratory costs in each State: 45 percent in Colorado and 72 percent in Ohio. In Colorado, State agencies had the largest estimated laboratory expenditures; whereas, in Ohio the largest estimated laboratory expenditures were by local agencies.

In terms of the estimated costs of analyzing the samples in each of the property or constituent groups for both surface- and ground-water samples, the largest laboratory costs in Colorado were for the analysis of inorganic constituents; the trace-elements group accounted for the second highest expenditure. In Ohio, the largest estimated costs were for prioritypollutants analyses; the second-largest estimated costs were for trace elements. Although 25 percent more trace-element samples were collected than priority-pollutant samples, the estimated laboratory costs of priority pollutants were more than 2 times higher than those of the trace-element samples because of the larger unit cost of the latter analyses. The laboratory costs are only part, though a major part, of the total costs of water-quality data-collection programs. Other costs, such as for sample collection, equipment costs, and program administration, vary greatly from agency to agency and could not be reliably estimated during this study. For many agencies, however, total program costs are believed to be more than twice the laboratory costs.

As previously stated, to gain a better insight of the relation between laboratory costs and total program costs, water-quality programs of the U.S. Geological Survey in the two States were examined. In Colorado, 22 U.S. Geological Survey programs reported total costs of about \$1.5 million. Estimated laboratory costs for these programs were $\$ 527,800$ or 35 percent of total program costs. In Ohio, $13 \mathrm{U} . \mathrm{S}$. Geological Survey programs reported total costs of about $\$ 1$ million. Estimated laboratory costs were $\$ 177,500$ or 18 percent of total program costs. For this agency's programs, as with those of other reporting agencies, laboratory costs varied from program to program depending on the number of samples and types of analyses performed. 
The major objective of this study is to determine if data collected by different agencies for various purposes, using different methods, can be aggregated for use in addressing water-quality questions of regional and national scope. The screening process discussed in this section was designed to identify data that will provide a common basis for further evaluation. This screening procedure does not imply that data not meeting the screening criteria are not useful, or that they do not meet their intended needs or fulfill mandated requirements of the agencies collecting the data.

The screening process is described in detail in the section entitled "Methods of Acquiring, Compiling, and Evaluating Information" and is summarized here by the following diagram:

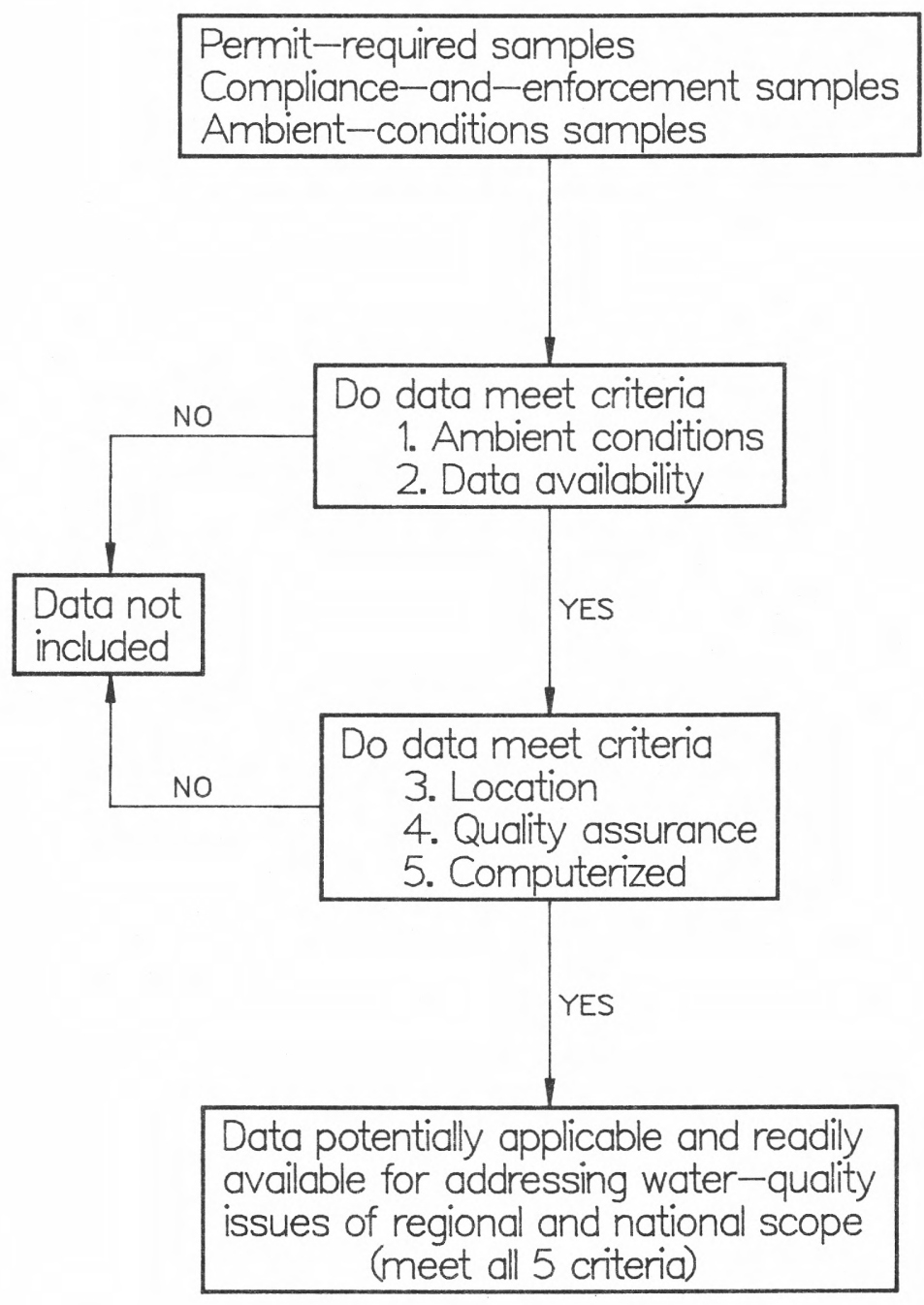


The original data base contained all samples, reported by all organizational categories, for all purposes, in all property or constituent groups. Those samples meeting criteria 1 and 2 were identified first, and, of these samples, those meeting criteria 3, 4, and 5 were identified. Detailed results of the screening process are presented in the "Supplemental Data" section (tables 10 to 21 ).

\section{Colorado}

\section{Surface Water}

The numbers of surface-water samples reported during 1984 that met the screening criteria and their estimated laboratory costs are summarized in figure 10A-B. About 34 percent of the total reported samples met all five screening criteria and represented 34 percent of the estimated laboratory costs. Fifty-one percent of the samples were not representative of ambient stream conditions, while only 2 percent of the samples were not publically available. An additional 13 percent either did not have adequate site-location information, were not quality assured, or were not computerized. After screening, a surface-water data base of about 105,000 samples remains potentially applicable to and available for addressing water-quality questions of regional and national scope.

Screening results for surface-water data for each of the organizational categories are summarized in figure 11A. (Permit-required samples are not included in these figures.) About 64 percent of all reported surface-water samples passed all five criteria when permit-required samples are excluded. About 80 percent or more of the data collected by Federal, State, and regional agencies met all criteria. However, only 8 percent of the data collected by local agencies met all the screening criteria.

After excluding the permit-required samples, most of the remaining samples were representative of ambient conditions and publically available. For the remaining three criteria (adequate site-location information, quality assured, and computerized data), the percentages of reported samples not meeting these criteria ranged from as much as 62 percent for local agencies to as little as 2 percent for regional agencies. Most samples had adequate location information and a quality-assurance program. The lack of computerized data was the most limiting of these three criteria for all organizational categories. 


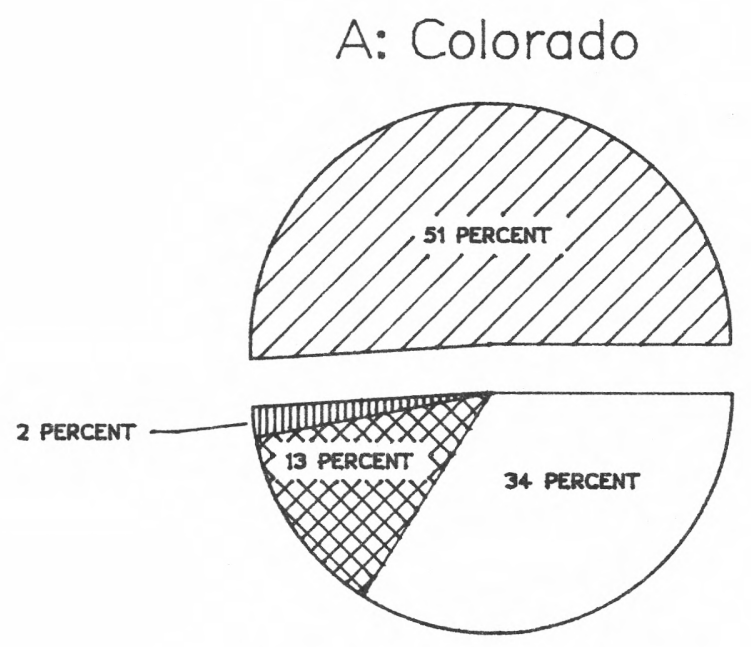

Total samples $=308,120$

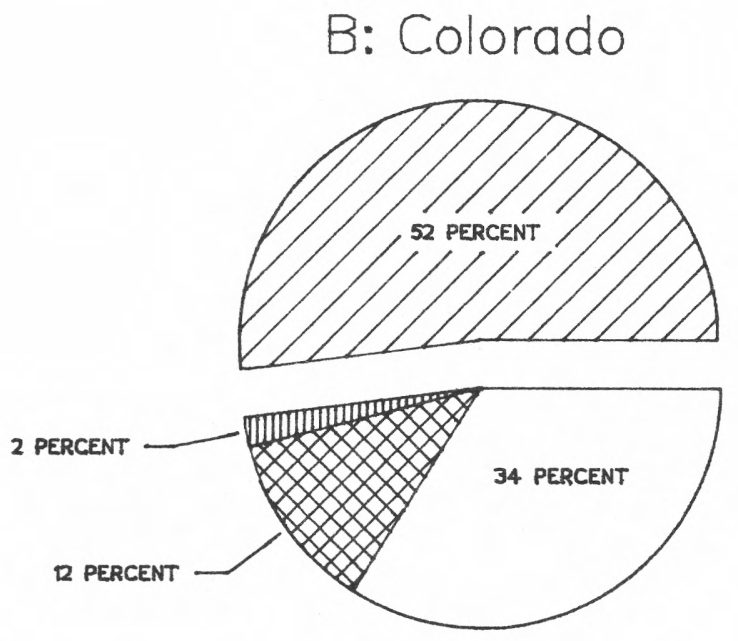

Total estimated laboratory costs $=\$ 11,110,000$
A: Ohio

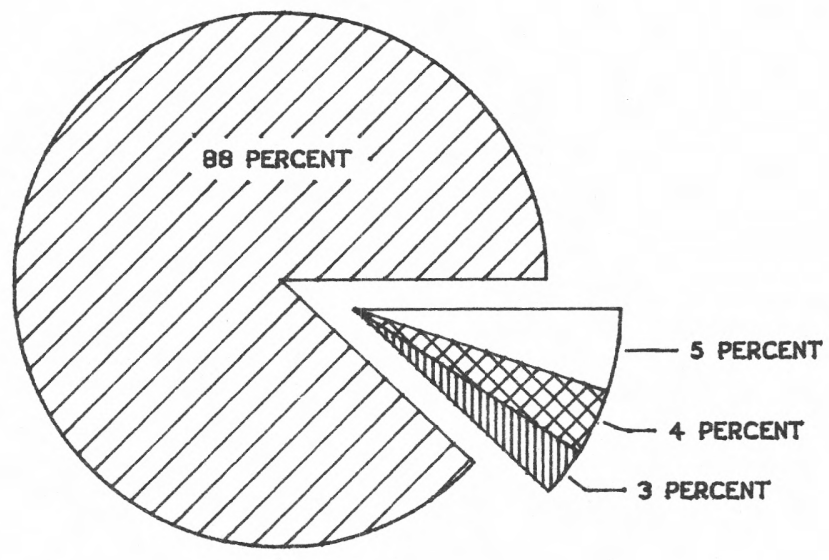

Total samples $=1,146,830$

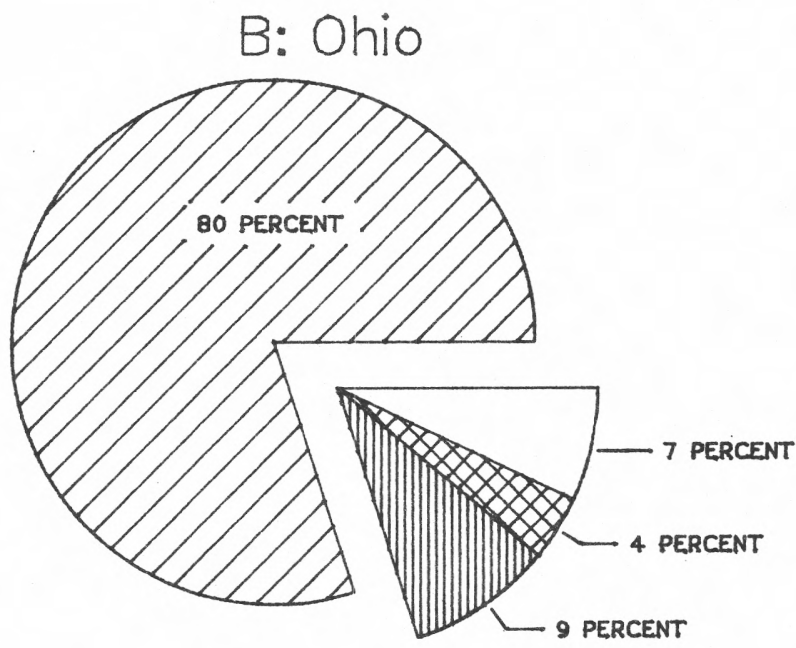

Total estimated laboratory costs $=\$ 44,600,000$

\section{EXPLANATION}

SAMPLES REPORTED TO MEET PERMIT REQUIREMENTS AND OTHER NON-AMBIENT SAMPLES; DID NOT MEET CRITERION 1

IIIIII SAMPLE INFORMATION NOT PUBLICALLY AVAILABLE; DID NOT MEET CRITERION 2

$\$$ SAMPLES NOT HAVING LOCATION INFORMATION, NOT QUALITY ASSURED,OR NOT COMPUTERIZED; DID NOT MEET CRITERION 3, 4, OR 5

SAMPLES MEETING ALL 5 CRITERIA

Figure 10.--Summary of screening results for Colorado and Ohio, 1984:

(A) surface-water samples, and (B) their estimated laboratory costs. 
A. COLORADO

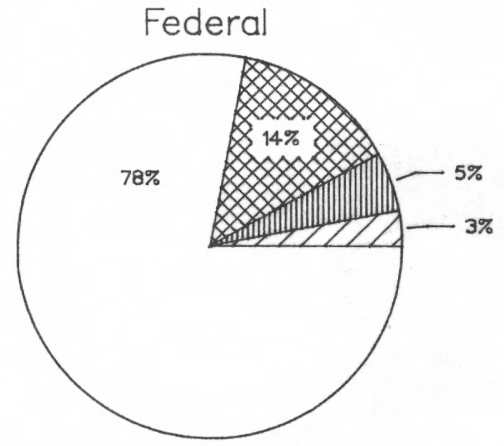

Samples $=30,420$

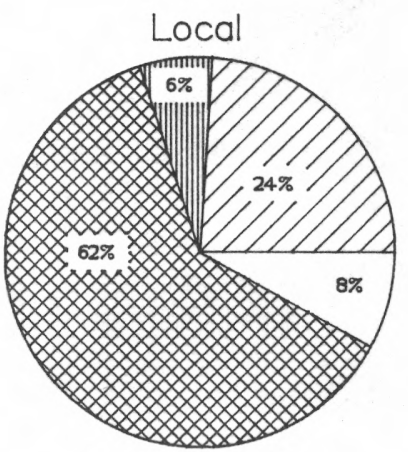

Samples $=41,780$

Federal

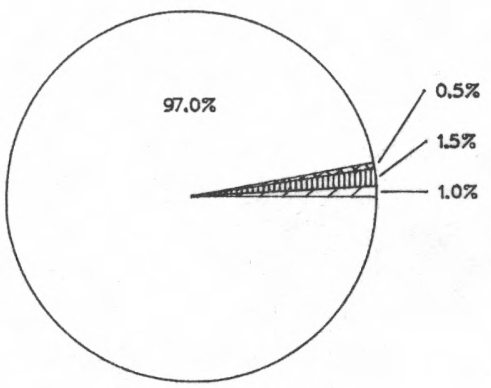

Samples $=11,360$

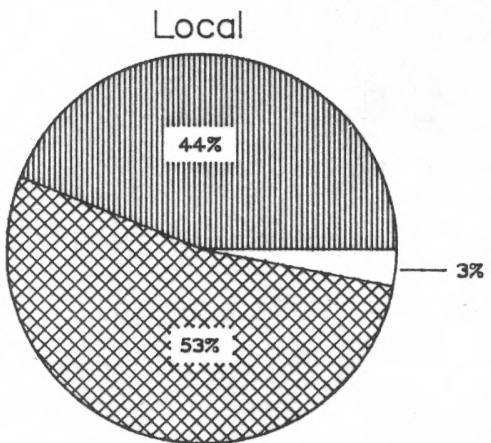

Samples $=78,590$

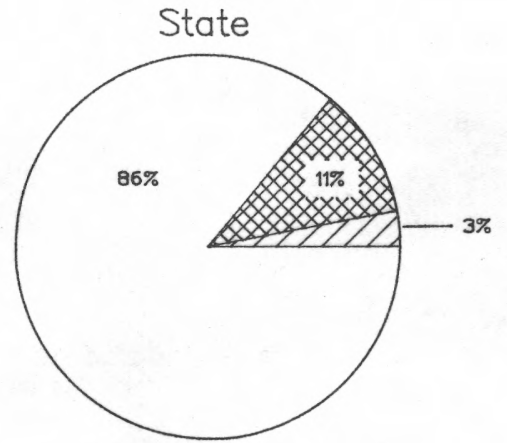

Samples $=73,080$

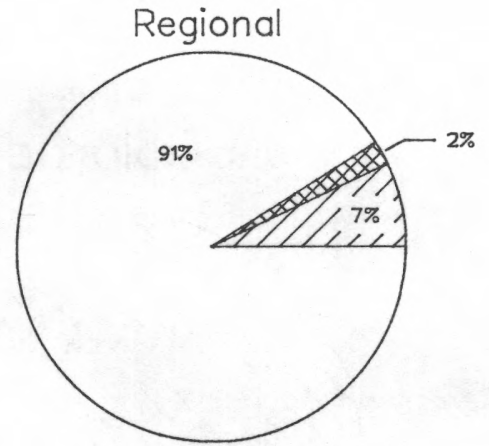

Samples $=16,490$

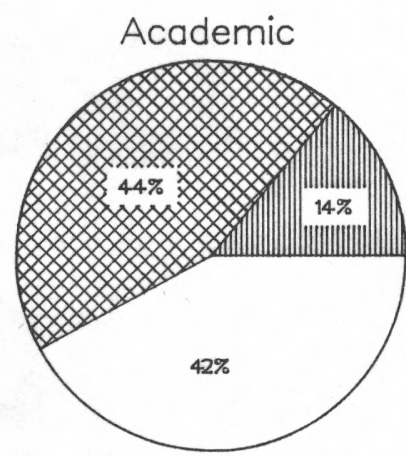

Samples $=2730$

B. $\mathrm{OHIO}$

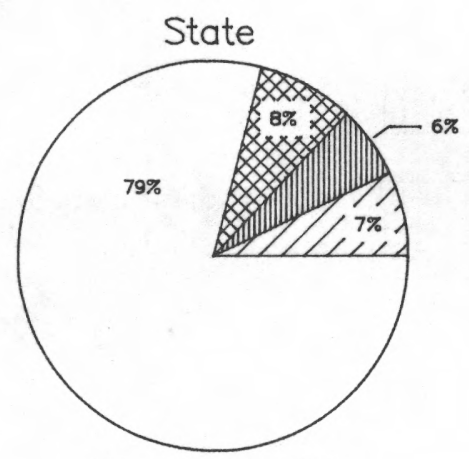

Samples $=37,650$

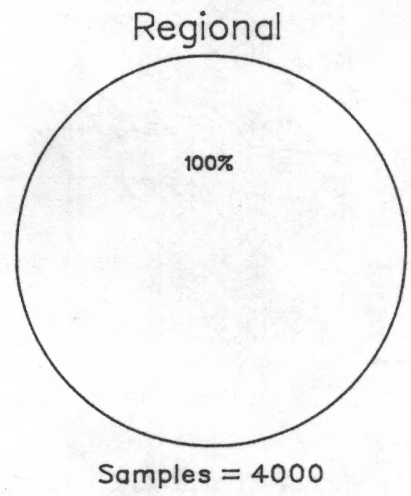

Samples $=4000$

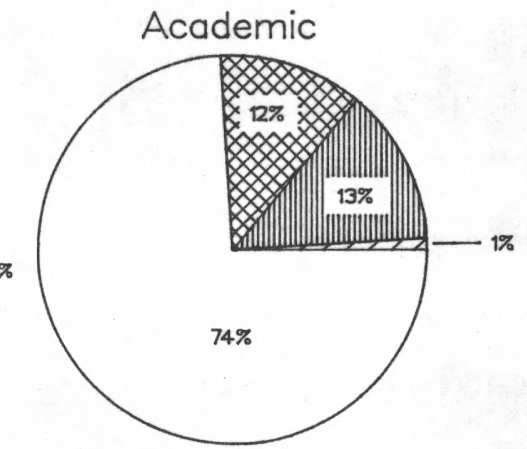

Somples $=12,930$

Figure 11.--Summary of screening results for surface-water samples for Federal, State, regional, local, and academic organizations, 1984:

(A) Colorado, and (B) Ohio. Permit-required samples are not included; see thc "Methods of Acquiring, Compiling and Evaluating Information" section for explanation of screening criteria. 
The screening results for the ground-water samples are summarized in figure 12A-B. Twenty-seven percent of the total number of reported samples met all five criteria and represented 13 percent of the estimated laboratory costs. About 48 percent were not representative of ambient conditions; these accounted for 49 percent of the costs. Thirteen percent of the samples were not available to the public primarily due to legal constraints on the data's availability. Twelve percent of the samples, which represented 7 percent of the estimated laboratory costs, either did not have adequate site-location information, were not quality assured, or were not computerized. A data base of about 12,000 ground-water samples remained after screening.

The ground-water data screening results for Colorado are summarized in figure $13 \mathrm{~A}$ for the different organizational categories. (Permit-required samples are not included in these figures.) About 64 percent of all reported ground-water samples passed all five criteria. Federal agencies' programs that accounted for 77 percent of the non-permit-required ground-water samples also had the largest percentage (61 percent) of samples meeting all five criteria. The only other ground-water samples meeting all five criteria were collected by local agencies.

State and local agencies and academic institutions reported a relatively small percentage (23 percent) of the ground-water samples in Colorado. Most of the ground-water samples collected by State agencies were for complianceand-enforcement activities; as a result, they were not representative of ambient conditions and not publically available. As was the case with the surface-water samples, the single most limiting factor affecting the utility of ground-water samples reported by local agencies for regional water-quality assessments was the lack of data in computer files.

For all reported samples in Colorado during 1984 (including permitrequired samples), criterion 1 (ambient conditions) had the greatest overall effect on the percentage of samples passing the screening process. Fifty-one percent of all samples, both surface- and ground-water, did not meet this criterion. Of the other criteria, criterion 5 (computerized data) is the most limiting. Twenty-five percent of the samples meeting the ambient conditions and data-availability criteria do not meet the computerized-data criterion. However, the percentage of samples that meet all criteria except criterion 5 is less than 3 percent, indicating that a large number of programs reported samples that do not meet more than one of the criteria. Computerizing the data that met all the criteria except 5 would result in only an 8-percent increase in the Colorado data potentially applicable to and readily available for addressing water-quality questions of regional and national scope. 


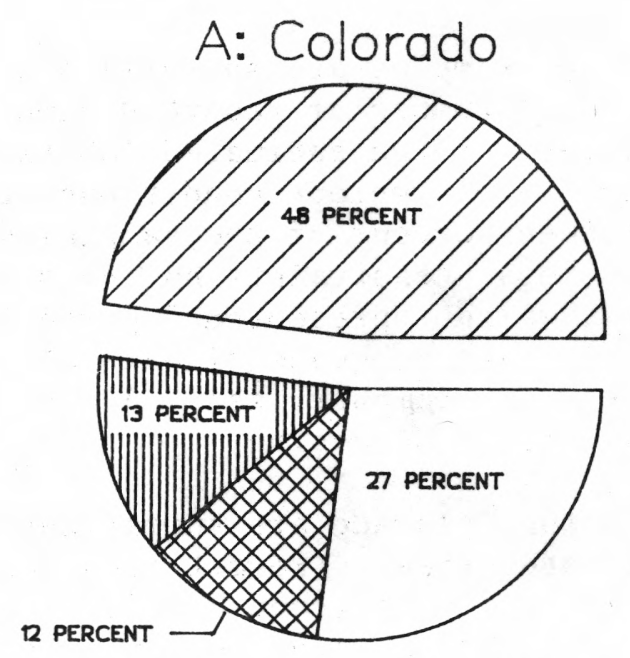

Total samples $=31,080$

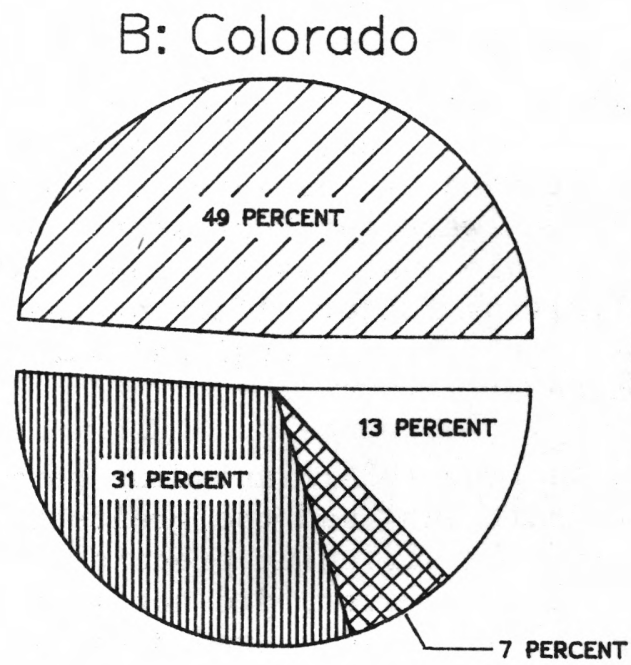

Total estimated laboratory costs $=\$ 2,380,000$

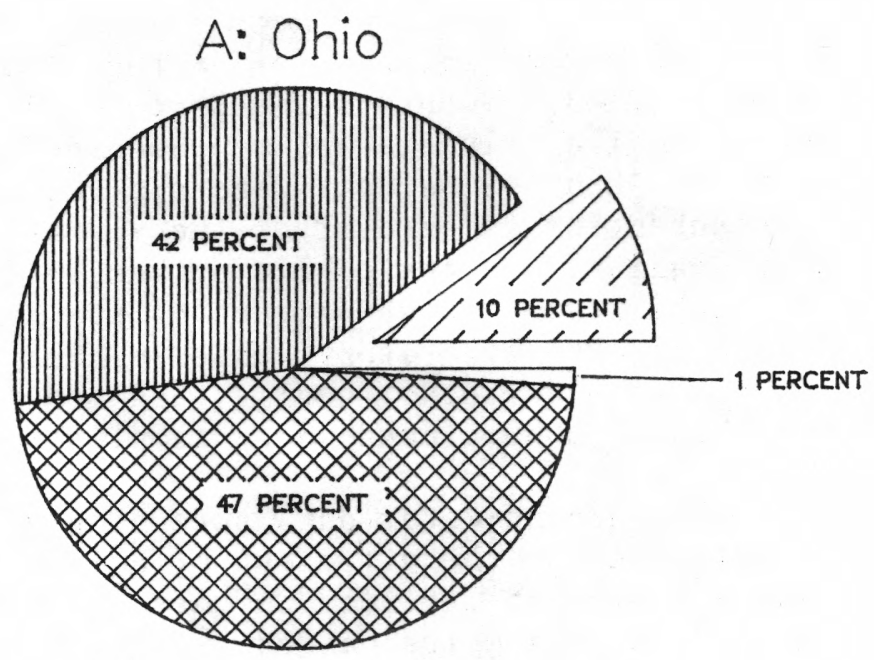

Total samples $=50,700$

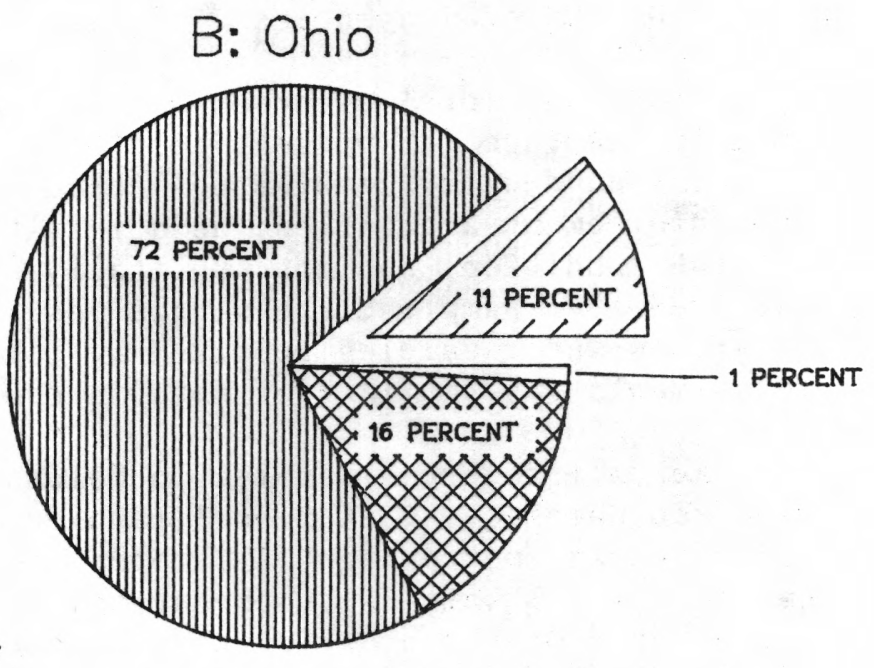

Total estimated laboratory costs $=\$ 4,990,000$

\section{EXPLANATION}

SAMPLES REPORTED TO MEET PERMIT REQUIREMENTS AND OTHER NON-AMBIENT SAMPLES; DID NOT MEET CRITERION 1

II IIIII SAMPLE INFORMATION NOT PUBLICALLY AVAILABLE; DID NOT MEET CRITERION 2

$\$$ SAMPLES NOT HAVING LOCATION INFORMATION, NOT QUALITY ASSURED, OR NOT COMPUTERIZED; DID NOT MEET CRITERION 3, 4, OR 5

$\square$ SAMPLES MEETING ALL 5 CRITERIA

Figure 12.--Summary of screening results for Colorado and Ohio, 1984:

$(A)$ ground-water samples, and $(B)$ their estimated laboratory costs. 
A. COLORADO
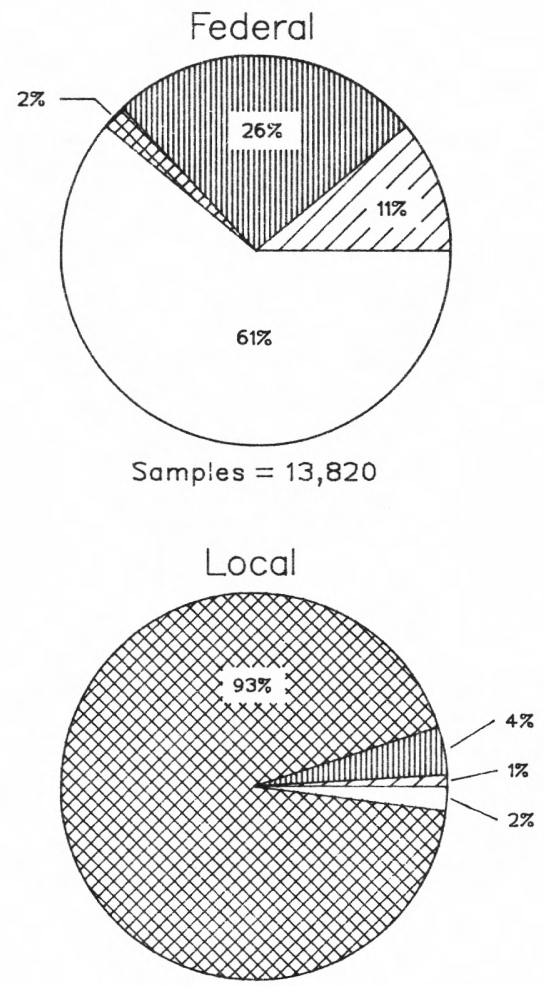

Samples $=3500$
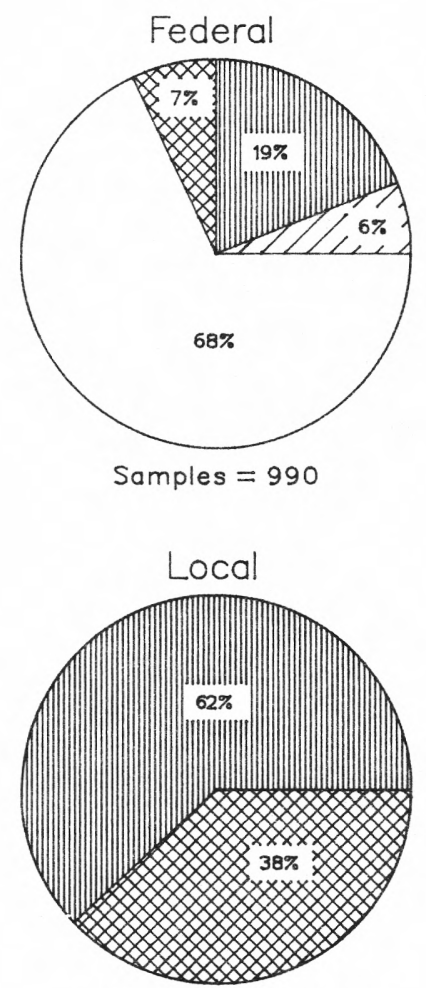

Samples $=33,830$
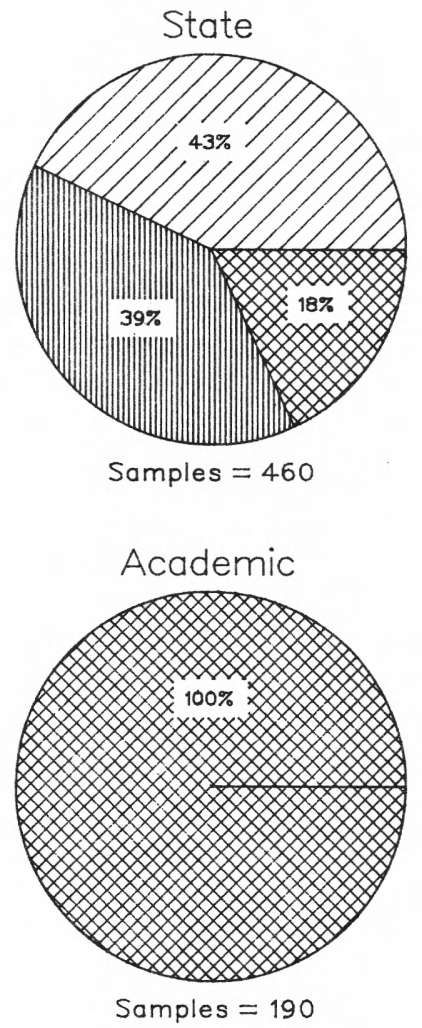

B. $\mathrm{OHIO}$

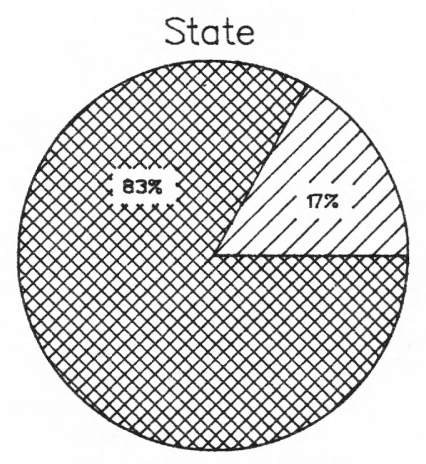

Samples $=13,060$

Academic

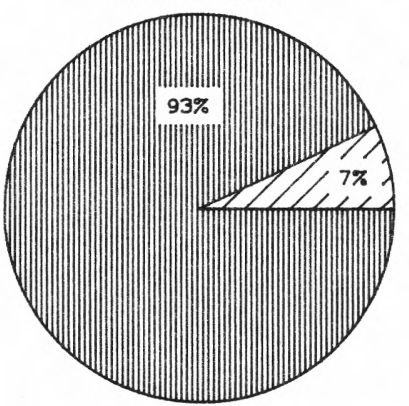

Samples $=150$
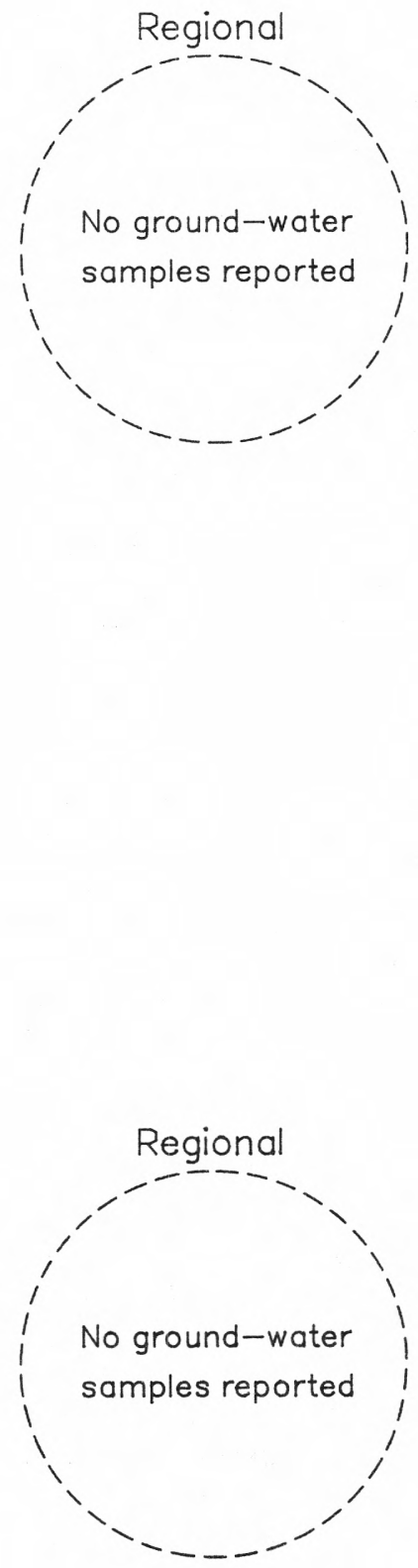

Figure 13.--Summary of screening results for ground-water samples for Federal, State, regional, local, and academic organizations, 1984: $(A)$ Colorado, and $(B)$ ohio. Permit-required samples are not included; see the "Methods of Acquiring, Compiling, and Evaluating Information" section for explanation of screening criteria. 


\section{Surface Water}

The screening results for surface-water samples and their associated estimated laboratory costs are summarized in figure 10A-B. Only 5 percent of the total number of samples ( 7 percent of estimated costs) met all five criteria. This represents a surface-water data base of about 56,000 samples potentially available for addressing water-quality questions of regional and national scope. Eighty-eight percent of the samples were not representative of ambient conditions. Most of these were permit-required samples. Three percent of the samples were not publically available, and 4 percent either did not have adequate site-location information, were not quality assured, or were not computerized.

Screening results for surface-water samples are summarized by organizational category in figure 11B. (Permit-required samples are not included.) About 82 percent of the surface-water samples reported by Federal, State, and regional agencies, and academic institutions met all criteria. Only 3 percent of the samples reported by local agencies met all criteria; the major limitation to using these data was the small percentage of data in computer files and limited availability of the data for public use.

\section{Ground Water}

The screening results for ground-water samples, and their associated estimated costs, are summarized in figure 12A-B. Only one percent of the samples ( 1 percent of estimated costs) met all five criteria. This represents 670 ground-water samples potentially available for addressing questions of regional and national scope. Ten percent of the samples (11 percent of estimated costs) were not representative of ambient conditions. Forty-two percent of the samples were not publically available, because of the large number of ground-water samples reported by local agencies that do not make their data available to the public. Forty-seven percent either did not have adequate site-location information, were not quality assured, or were not computerized. The major limitation was the lack of data in computer files. 
The screening results for ground-water samples by organizational category are summarized in figure 13B. (Permit-required samples are not included.) Sixty-eight percent of samples reported by Federal agencies, and only samples reported by Federal agencies, met all five criteria. The major limitation for Federal-agency samples was lack of data availability. Some Federal agencies were collecting ground-water data that was unavailable at the time of this study, pending review and publication. Limitations on using samples reported by the other organizational groups varied. Samples reported by State agencies were affected by the data not being computerized and the lack of site-location information. Ground-water samples reported by local agencies had the same limitations as the surface-water samples reported by these groups; namely, lack of data available to the public and data not being computerized. Most (93 percent) of the ground-water samples reported by academic institutions were not available to the public. Regional agencies did not report any ground-water samples.

Overall in Ohio, the abundance of nonambient data (including permitrequired data) was the greatest limitation for both the surface- and groundwater samples for assessing water-quality conditions. The second was the lack of data in computerized files. Three percent of all surface-water samples and 47 percent of all ground-water samples met all the criteria except number 5 (computerized data). If these data were put into computer files, the number of samples potentially applicable to and readily available for addressing water-quality questions would increase by about 55,500, which would approximately double the data base.

\section{Comparison Between States}

Although more samples were reported in Ohio than in Colorado, fewer of the Ohio samples met all criteria; thus, fewer are potentially applicable to and readily available for addressing water-quality questions of regional and national scope. The total number of samples and their estimated laboratory costs, before and after the screening, are summarized for both States in table 5. For Colorado, 34 percent of all reported samples met all five screening criteria ( 31 percent of the estimated costs). In contrast, for Ohio, 5 percent of the samples ( 6 percent of the estimated costs) remained after the screening. Regional agencies in both States had the largest percentage of samples remaining after the screening--93 percent in Colorado and 100 percent in Ohio. In both States, local agencies had the smallest number of samples meeting all criteria, the noncomputerized data being one of the most limiting criteria. Excluding the permit-required samples, this criterion was the largest limitation for all data reported in both States. 
Table 5.--Numbers and percentages of samples and estimated laboratory costs (surface water and ground water combined) before and after screening, by source of data, Colorado and ohio, 1984

[Cost estimates are based on 1984 U.S. Geological Survey laboratory costs; --, not applicable]

\begin{tabular}{|c|c|c|c|c|c|c|c|c|c|c|c|c|}
\hline \multirow[b]{3}{*}{ Source of data } & \multicolumn{6}{|c|}{ Colorado } & \multicolumn{6}{|c|}{ Ohio } \\
\hline & \multicolumn{2}{|c|}{ Before screening } & \multicolumn{2}{|c|}{ After screening } & \multicolumn{2}{|c|}{ Remaining } & \multicolumn{2}{|c|}{ Before screening } & \multicolumn{2}{|c|}{ After screening } & \multicolumn{2}{|c|}{ Remaining } \\
\hline & $\begin{array}{l}\text { Number of } \\
\text { samples }\end{array}$ & $\begin{array}{c}\text { Estimated } \\
\text { cost } \\
\text { (thousands } \\
\text { of dollars }\end{array}$ & $\begin{array}{l}\text { Number of } \\
\text { samples }\end{array}$ & $\begin{array}{l}\text { Estimated } \\
\text { cost } \\
\text { (thousands } \\
\text { of dollars }\end{array}$ & $\begin{array}{l}\text { Number of } \\
\text { samples } \\
\text { (percent) }\end{array}$ & $\begin{array}{l}\text { Estimated } \\
\text { cost } \\
\text { (thousands } \\
\text { of dollars }\end{array}$ & $\begin{array}{l}\text { Number of } \\
\text { samples } \\
\text { s }\end{array}$ & $\begin{array}{l}\text { Estimated } \\
\text { cost } \\
\text { (thousands } \\
\text { of dollars }\end{array}$ & $\begin{array}{l}\text { Number of } \\
\text { samples }\end{array}$ & $\begin{array}{l}\text { Estimated } \\
\text { cost } \\
\text { (thousands } \\
\text { of dollars }\end{array}$ & $\begin{array}{l}\text { Number of } \\
\text { samples } \\
\text { (percent) }\end{array}$ & $\begin{array}{c}\text { Estimated } \\
\text { cost } \\
\text { (thousands } \\
\text { of dollars }\end{array}$ \\
\hline \multicolumn{13}{|l|}{ Federal: } \\
\hline $\begin{array}{l}\text { U.S. Geological } \\
\text { Survey. }\end{array}$ & 19,960 & 530 & 18,910 & 475 & 95 & 90 & 8,410 & 178 & 8,410 & 178 & 100 & 100 \\
\hline $\begin{array}{l}\text { Other Department of the } \\
\text { Interior agencies. }\end{array}$ & 11,490 & 368 & 10,170 & 332 & 89 & 90 & 120 & 3 & 60 & 1 & 50 & 38 \\
\hline $\begin{array}{l}\text { U.S. Environmental } \\
\text { Protection Agency. }\end{array}$ & 2,360 & 320 & 0 & 0 & 0 & 0 & 240 & 11 & 0 & 0 & 0 . & 0 \\
\hline Other Federal agencies. & 10,430 & 964 & 3,010 & 149 & 29 & 15 & 3,580 & 162 & 3,270 & 144 & 91 & 89 \\
\hline $\begin{array}{c}\text { Total, Federal } \\
\text { agencies. }\end{array}$ & 44,240 & 2,182 & 32,090 & 956 & 72 & 44 & 12,350 & 354 & 11,740 & 323 & 95 & 91 \\
\hline \multicolumn{13}{|l|}{ Regional: } \\
\hline Intrastate agencies. & 16,490 & 495 & 15,010 & 436 & 91 & 88 & -- & -- & -- & -- & -- & -- \\
\hline Interstate agencies. & -- & -- & -- & -- & -- & -- & 4,000 & 385 & 4,000 & 385 & 100 & 100 \\
\hline $\begin{array}{l}\text { Total, regional } \\
\text { agencies. }\end{array}$ & 16,490 & 495 & 15,010 & 436 & 91 & 88 & 4,000 & 385 & 4,000 & 385 & 100 & 100 \\
\hline State agencies. & 73,540 & 2,794 & 62,610 & 2,452 & 85 & 88 & 50,710 & 2,561 & 29,530 & 1,417 & 58 & 55 \\
\hline Local agencies. & 45,280 & 1,828 & 3,450 & 217 & 8 & 12 & 112,420 & 9,494 & 2,080 & 83 & 2 & 1 \\
\hline Academic institutions. & 2,920 & 107 & 1,140 & 56 & 39 & 52 & 13,080 & 1,090 & 9,600 & 817 & 73 & 75 \\
\hline $\begin{array}{l}\text { Subtotals, all } \\
\text { organizations. }\end{array}$ & 182,470 & 7,406 & 114,300 & 4,117 & 63 & 56 & 192,560 & 13,884 & 56,950 & 3,025 & 30 & 22 \\
\hline $\begin{array}{l}\text { Subtotals, } \\
\text { permit-required. }\end{array}$ & 156,730 & 6,078 & 0 & 0 & 0 & 0 & $1,005,000$ & 35,700 & 0 & 0 & 0 & 0 \\
\hline Totals (rounded) & 339,200 & 13,480 & 114,300 & 4,830 & 34 & 31 & $1,197,560$ & 49,580 & 56,950 & 3,020 & 5 & 6 \\
\hline
\end{tabular}


For each major property and constituent group, the total number of samples and their estimated costs before and after the screening are summarized in table 6 . In Colorado, over 50 percent of trace-element and nutrient samples passed the screening step. In Ohio, the group with the largest number of samples meeting all criteria was physical properties, however, this represented only 2 percent of the total number of physical properties before screening. Inorganic constituents, nutrients, and sediment also had large numbers of samples remaining but represented only small percentages of the number of samples before screening.

Excluding permit-required samples, the lack of data in computer files was the biggest limitation in both States on the applicability of the data for addressing water-quality questions of regional and national scope. For Colorado, if all data were computerized, the number of samples potentially applicable to and readily available for addressing water-quality questions of regional and national scope would have increased by only 8 percent. However, for Ohio, if all data were computerized, the number of samples would increase by 98 percent. The large difference in the effect of this criterion between the States mainly is due to the large number of samples collected by Federal agencies in Colorado, which have computerized data, and the large number of samples collected by local agencies in Ohio, which do not have computerized data.

The 1984 data base potentially applicable to and readily available for the analysis of water-quality issues consists of 114,300 samples in Colorado and 57,000 samples in Ohio. These totals represent both surface and ground water and all property and constituent groups. These totals also represent 34 percent of all samples available before the screening in Colorado and 5 percent of all samples available before the screening in Ohio. When permitrequired samples are excluded these totals represent 63 percent of all samples in Colorado and 30 percent of all samples in Ohio.

The larger decrease in samples for Ohio after screening is the result of the greater proportion of samples collected in that state to meet permit requirements. In Colorado, the majority of samples before and after the screening were collected by State agencies. In Ohio, State agencies had the largest number of samples remaining after screening, but regional agencies had the largest percentage (100 percent) of samples remaining.

It should be emphasized that even this data base is not necessarily all applicable to the aforementioned regional and national issues. In Phase II, a detailed evaluation of the programs' sample-collection techniques, qualityassurance procedures, and laboratory-analytical methods will be undertaken. In Phase III, data from programs with adequate sampling, quality assurance, and laboratory procedures will be combined to provide a data base for addressing water-quality questions of regional and national scope. 
Table 6.--Numbers and percentages of samples and estimated laboratory costs (surface water and ground water combined)

before and after screening, by property and constituent groups, Colorado and Ohio, 1984

[Cost estimates are based on 1984 U.S. Geological Survey laboratory costs]

\begin{tabular}{|c|c|c|c|c|c|c|c|c|c|c|}
\hline \multirow[b]{3}{*}{ Constituent group } & \multicolumn{5}{|c|}{ Colorado } & \multicolumn{5}{|c|}{ Ohio } \\
\hline & \multicolumn{2}{|c|}{ Before screening } & \multicolumn{2}{|c|}{ After screening } & \multirow[b]{2}{*}{$\begin{array}{l}\text { Percentage } \\
\text { of samples } \\
\text { (also costs) } \\
\text { remaining }\end{array}$} & \multicolumn{2}{|c|}{ Before screening } & \multicolumn{2}{|c|}{ After screening } & \multirow[b]{2}{*}{$\begin{array}{c}\text { Percentage } \\
\text { of samples } \\
\text { (also costs) } \\
\text { remaining }\end{array}$} \\
\hline & $\begin{array}{l}\text { Number of } \\
\text { samples }\end{array}$ & $\begin{array}{l}\text { Estimated } \\
\text { cost } \\
\text { (thousands } \\
\text { of dollars) }\end{array}$ & $\begin{array}{l}\text { Number of } \\
\text { samples }\end{array}$ & $\begin{array}{c}\text { Estimated } \\
\text { cost } \\
\text { (thousands } \\
\text { of dollars) }\end{array}$ & & $\begin{array}{c}\text { Number of } \\
\text { samples }\end{array}$ & $\begin{array}{c}\text { Estimated } \\
\text { cost } \\
\text { (thousands } \\
\text { of dollars) }\end{array}$ & $\begin{array}{l}\text { Number of } \\
\text { samples }\end{array}$ & $\begin{array}{l}\text { Estimated } \\
\text { cost } \\
\text { (thousands } \\
\text { of dollars) }\end{array}$ & \\
\hline Physical properties & 119,300 & 1,617 & 38,710 & 524 & 32 & 511,900 & 6,936 & 12,370 & 168 & 2 \\
\hline Inorganic constituents & 62,270 & 2,943 & 28,660 & 1,354 & 46 & 370,220 & 17,493 & 7,990 & 378 & 2 \\
\hline Trace elements & 13,440 & 1,326 & 7,310 & 695 & 54 & 91,210 & 11,154 & 5,040 & 616 & 6 \\
\hline Major metals & 13,810 & 127 & 5,700 & 52 & 41 & 31,910 & 294 & 3,700 & 34 & 12 \\
\hline Nutrients & 28,110 & 1,182 & 14,540 & 633 & 52 & 69,990 & 3,041 & 8,820 & 383 & 13 \\
\hline Organic substances & 35,870 & 2,638 & 6,570 & 483 & 18 & 23,550 & 1,782 & 4,160 & 306 & 18 \\
\hline Priority pollutants & 4,410 & 1,810 & 244 & 101 & 6 & 15,160 & 6,097 & 1,100 & 452 & 7 \\
\hline Pesticides & 1,870 & 564 & 90 & 30 & 5 & 3,410 & 1,029 & 1,800 & 543 & 53 \\
\hline Radiochemicals & 1,200 & 32 & 260 & 6 & 22 & 650 & 17 & 50 & 1 & 8 \\
\hline Biota & 52,450 & 1,180 & 9,960 & 221 & 19 & 71,730 & 1,614 & 4,820 & 109 & 7 \\
\hline Sediment & 4,940 & 25 & 2,120 & 10 & 43 & 7,800 & 39 & 7,100 & 36 & 91 \\
\hline
\end{tabular}




\section{SUMMARY AND CONCLUSIONS}

Serious questions have been raised by Congress about the usefulness of water-quality data for addressing issues of regional and national scope and, especially, for characterizing the current quality of the Nation's streams and ground water. In response, the U.S. Geological Survey has undertaken a pilot study to characterize existing water-quality data-collection programs in two sample States--Colorado and Ohio--and to evaluate the applicability and availability of these programs for addressing water-quality questions of regional and national scope. This report presents the results from the first phase of the study--a description of present (1984) water-quality datacollection programs, including costs, in the two States--and compares the characteristics of those programs to a set of broad criteria appropriate for addressing water-quality questions of regional and national scope.

Information on water-quality data-collection programs active during 1984 in Colorado and Ohio was obtained by means of a questionnaire that was furnished to public agencies and academic institutions. Forty-eight organizations with 115 programs were identified in Colorado, and 42 organizations with 88 programs were identified in Ohio. All programs were separated into three purpose categories according to their main objectives: (1) Meeting permit requirements; (2) undertaking compliance-and-enforcement activities; and (3) characterizing ambient water-quality conditions.

About four times as many water-quality samples were reported for Ohio as for Colorado. This major difference resulted from the larger number of samples collected to meet permit requirements in Ohio, where there are about 52 percent more NPDES permits than in Colorado. Samples collected to meet permit requirements represent 46 percent of the total number of samples in Colorado and 84 percent of the total number of samples in Ohio. The number of samples collected for compliance-and-enforcement activities represents 12 percent of the total in Colorado and 1 percent of the total in Ohio. The number of samples collected for characterizing ambient water-quality conditions was nearly equal in both States; however, this total represents 42 percent of the total number of samples collected in Colorado and only 15 percent of those collected in Ohio. 
Surface-water samples represented 90 percent of all the samples reported in Colorado and 96 percent of all the samples reported in Ohio. This is a reflection of the greater usage of surface water in both States and also the less frequent sampling requirements for ground water. The largest number of surface-water samples was collected for the physical-properties and inorganic constituent groups in both Colorado and Ohio, indicating the emphasis on gross, inexpensive measurements of water quality. For ground water, samples were analyzed most frequently in Colorado for biota, physical properties, and inorganic constituents; and samples were analyzed most frequently in ohio for biota and major metals. Among the least frequently analyzed were the most costly analyses: priority pollutants and pesticides. These represented 1 percent of all samples analyzed in Colorado and 9 percent in Ohio.

If permit-required samples are excluded, State agencies in Colorado reported the largest number of surface-water samples; in Ohio, local organizations reported the largest number. In Colorado, Federal agencies reported the largest number of ground-water samples (93 percent); in Ohio, local agencies reported the largest number of ground-water samples ( 70 percent).

Seventy-five percent of the questionnaires returned in Colorado reported program costs which totaled about $\$ 6$ million, whereas, in Ohio, 59 percent of the questionnaires reported program costs which totaled about $\$ 10.7$ million. Because the cost information obtained from the questionnaires was incomplete and somewhat inconsistent, estimates of laboratory costs were developed from other sources.

The total estimated laboratory costs of all sample analyses in Colorado during 1984 was more than $\$ 13.4$ million. In Colorado, permit-required sampling represented 45 percent of estimated laboratory costs and 46 percent of all samples; sampling for compliance-and-enforcement activitites represented 17 percent of estimated laboratory costs and 12 percent of all samples; and sampling for characterization of ambient conditions represented 38 percent of estimated laboratory costs and 42 percent of all samples. Total estimated laboratory costs of all samples analyzed in Ohio during 1984 was about $\$ 50$ million. In Ohio, sampling to meet permit requirements represented 72 percent of total estimated laboratory costs and 84 percent of all samples; sampling for compliance-and-enforcement activities represented 2 percent of total estimated laboratory costs and 1 percent of all samples; and sampling for characterization of ambient conditions represented 26 percent of estimated laboratory costs and 15 percent of all samples.

When permit-required samples are excluded, estimated laboratory costs in Colorado indicated that the largest expenditures for surface-water analyses were by State agencies. Conversely, the largest expenditures for ground-water analyses were by Federal agencies. In Ohio, the largest expenditures (excluding samples to meet permit requirements) for both surface- and groundwater analyses were by local agencies. 
Water-quality data-collection programs identified from the questionnaires were tested against a set of five broad screening criteria to evaluate their potential applicability and availability for addressing water-quality questions of regional and national scope. The five screening criteria are:

1. Do the data represent ambient stream or aquifer conditions, as opposed to effluent or treated water?

2. Are the data available for public use?

3. Can the sampling sites be readily located?

4. Is quality-assurance documentation available?

5. Are the data in computer files?

For Colorado, 34 percent of all samples, representing 31 percent of estimated laboratory costs, met all five criteria. For Ohio, 5 percent of all samples, representing 6 percent of estimated laboratory costs, met all five criteria. When permit-required samples are excluded these totals represent 63 percent of all samples in Colorado and 30 percent of all samples in Ohio. The larger number of samples not meeting the criteria in Ohio resulted from the greater proportion of effluent samples that did not meet the ambientconditions criterion. In both States, local agencies had the fewest samples passing the screening step; the computerized-data criterion (number 5) caused the largest number of these samples to be excluded. Regional agencies had the largest percentage of samples meeting all the screening criteria, 91 percent in Colorado and 100 percent in Ohio.

The 1984 data base, potentially applicable to and readily available for addressing water-quality questions of regional and national scope, consists of about 114,300 samples in Colorado and about 57,000 samples in Ohio. These totals represent both surface- and ground-water samples in all property and constituent groups. In Colorado, if all samples had met the computerized-data criterion, the number of samples readily available would increase by 8 percent. For Ohio, if all samples had met the computerized-data criterion, the number of samples would approximately double. This difference between States reflects the differences in the organizations operating the programs. In Colorado, most samples were collected by Federal or State agencies; in Ohio, most samples were collected by local agencies. The Federal government, because of the large quantities of data for which it is responsible, already has computerized-data bases, but a number of smaller organizations, such as local governments, have not entered their data into computer files.

A total of $\$ 21$ million was estimated to have been spent during 1984 for analyses of samples collected to characterize ambient conditions and for compliance-and-enforcement activities in the two States, with almost $\$ 8$ million of those costs representing the data that are potentially applicable to and readily available for the examination of the previously identified water-quality questions of regional and national scope. These laboratory costs represent a part of the water-quality data-collection programs' total costs. Total costs could not be reliably estimated during this study. 
Blodgett, J. E., 1983, Summary of hearings of "National Environmental Monitoring": Washington, D.C., Congressional Research Service, 20 p.

Cable, L. W., 1982, The Federal water data coordination program 1964-1980:

U.S. Geological Survey Office of Water Data Coordination, 47 p.

Feltz, H. R., Anthony, E. R., and Sadler, Pamela, eds., 1983, Water-quality laboratory services catalog: U.S. Geological Survey Open-File Report $83-758,130 \mathrm{p}$.

Solley, W. B., Chase, E. B., and Mann, W. B., IV, 1983, Estimated use of water in the United States in 1980: U.S. Geological Survey Circular 1001, 56 p.

U.S. Bureau of the Census, 1981a, Advance reports, 1980 census of population and housing, Colorado: Washington, D.C., 43 p. 1981b, Advance reports, 1980 census of population and housing, Ohio: Washington D.C., $43 \mathrm{p}$.

U.S. Bureau of Land Management, 1983, Public land statistics 1983: Washington, D.C., 231 p. 
SUPPLEMENTAL DATA 
WATER-QUALITY MONITORING ACTIVITIES QUESTIONNAIRE (PHASE I)

OHIO DISTRICT, U.S. GEOLOGICAL SURVEY

\section{AGENCY AND PROGRAM INFORMATION}

1. Agency Name:

2. Division:

3. Address:

4. Phone: 5. Contact Name

6.1 Agency Type: .1 Federal .2 State .3 County .4 City .5 Academic .6 Private .7 other

6.2 Area of Responsibility: .1 Statewide .2 County . 3 Regional (multi-state) .4 Regional (within state) .5 City .6 Site

7.0 PROGRAM:

7.1 Type: .1 Scheduled long-term .3 Surface water .4 Ground water

7.2 Program Name:

7. 3 Study Name:

7.4 Number of Site(s):

7.5 Length of Program: Dates: Start End

7.6a Was the program designed to study an area that was previously identified as being polluted? .1 Yes .2 No

7.6b Were data from this program the result of analyses of effluents or samples from sites in close proximity to point sources of pollution? .3 Yes .4 No 
7.7 Program Objectives: .1 Define near-natural conditions

.2 Define existing water-quality conditions

.3 Detect trends

.4 Detect effects of 1 and use

.5 Compute loads

.6 Determine suitability for major use

.7 Determine compliance with criteria and standards

.8 Determine effects of pollution-control programs

.9 Other

7.8 Geographic Area: .1 Statewide .2 County . 3 Regional (within state)

.4 Drainage basin .5 Site-specific .6 City .7 Other

7.9 Drainage Basin:.1 Cuyahoga

.4 Hocking

.7 Muskingum

.10 Statewide

.2 Grand

.5 L. Miami

.8 Sandusky

.3 G. Miami

.6 Maumee

.9 Scioto

7.10 Sampling Locations: . I Lat/Long .2 Mapped .3 other

7.11 Data Availability: .1 Not available .2 Restricted .3 Unrestricted

7.12 Surface Water: .1 Flow data are available at or near the collection site Yes No

.2 Data type: Instantaneous Instantane
Lake Depth

7.13 Ground Water: .1 Aquifer known .2 Depth interval known Yes Yes Daily

$\longrightarrow$

\subsection{FUNDING}

8.1 Cooperator(s):

8.2 Funding (thousands of $\$$ )

8.3 Funding source(s) (in \%): .1 Federal .3 Local .4 Private .2 State .5 other

\subsection{Comments:}


8.5 References:

\section{PHYSICAL/FIELD MEASUREMENTS}

9. $\mathrm{pH}, \mathrm{SC}, \mathrm{T}, \mathrm{DO}$, Turbidity, Alkalinity, Acidity, Color, Other

9.1

9.2

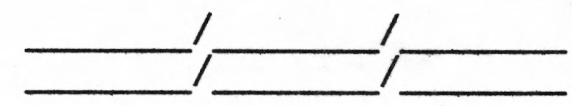

III. CHEMICAL MEASUREMENTS

10. MAJOR INORGANICS:

$\mathrm{Ca}, \mathrm{Mg}, \mathrm{Na}, \mathrm{K}, \mathrm{Cl}, \mathrm{F}, \mathrm{SO4}, \mathrm{N03}$, Acidity/Alkalinity, pH, SC, Other $10.1+10.2$

11. TRACE ELEMENTS:

As, $\mathrm{Ba}, \mathrm{Be}, \mathrm{Cd}, \mathrm{Co}, \mathrm{Cr}, \mathrm{Cu}, \mathrm{Fe}, \mathrm{Hg}, \mathrm{Li}, \mathrm{Mn}, \mathrm{Mo}, \mathrm{Pb}, \mathrm{Se}, \mathrm{Sr}, \mathrm{V}, \mathrm{Zn}$, Other 11.1 11.2

12. NUTRIENTS:

Nitrogen Forms; Phosphorus Forms

12.1

12.2

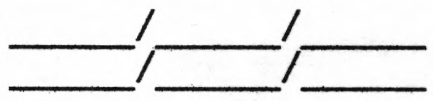

13. ORGANICS:

13.0 A11:

13.0 .1

13.0.2

13.1 GROSS MEASUREMENTS:

Organic/Inorganic Carbon, Detergents, $0 i 1$ \& Grease, Phenols, Tannin \& Lignin, Other

13.1 .1

13.1 .2

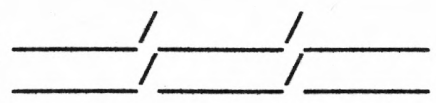

13.2 PRIORITY POLLUTANTS:

Acid-Extractable, Base/Neutral-Extractable, Volatile, Other Major Compounds Analyzed For:

13.2. 1

13.2. 2

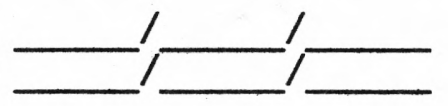




\section{3 PESTICIDES}

13.3.0 All:

13.3.0.1

13.3.0.2

13.3.1 Carbamate Insecticides:

13.3.1.1

13.3.1.2

13.3.2 Chlorophenoxy Acid Herbicides:

13.3.2.1

13.3.2.2
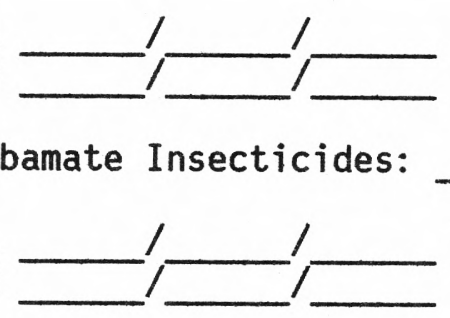

13.3.3 Organochlorine Insecticides:

13.3.3.1

13.3.3.2

13.3.4 Organophosphorus Insecticides:

13.3.4.1

13.3.4.2

13.3.5 Triazine Herbicides:

13.3.5.1

13.3.5.2

14. RADIOCHEMICAL:

14.1

14.2

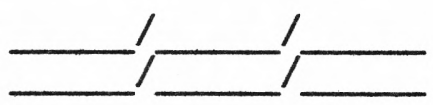

15. CHEMICAL ANALYSIS OF TISSUE:

15.1

15.2

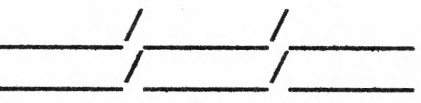


17. CHEMICAL LABORATORY AND QUALITY ASSURANCE:

: Used : Refer. : Split : Spiked : QA per- :None : Items :

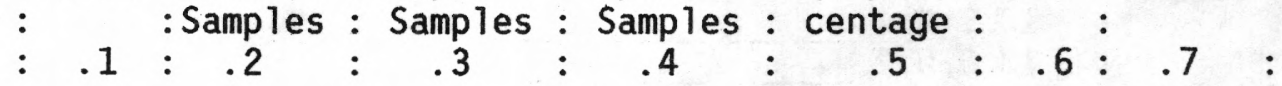

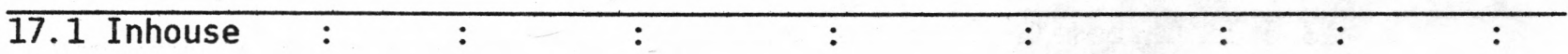

\begin{tabular}{lllllllll}
\hline 17.2 Federal & $:$ & $:$ & $:$ & $:$ & $:$ & $:$ & $:$ & $:$ \\
\hline 17.3 State & $:$ & $:$ & $:$ & $:$ & $:$ & $:$ & $:$ & $:$ \\
\hline 17.4 County & $:$ & $:$ & $:$ & $:$ & $:$ & $:$ & $:$ & $:$ \\
\hline 17.5 Private & $:$ & $:$ & $:$ & $:$ & $:$ & $:$ & $:$ & $:$ \\
\hline 17.6 0ther & $:$ & $:$ & $:$ & $:$ & $:$ & $:$ & $:$ & $:$ \\
\hline
\end{tabular}

18.0 Sample Collection: Name

Address

Contact:

Phone

19.0 Sample Analysis: Name

Address

Contact:

Phone

IV. BIOLOGICAL MEASUREMENTS

20. BACTERIA

20.1 INDICATOR BACTERIA:

Total Coliform, Fecal Coliform, Fecal Streptoccal Bacteria, Other

20.1. 1

20.1. 2

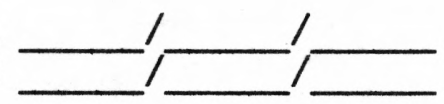


20.2 PATHOGENIC BACTERIA:

Salmonella, Shigella, Other

20.2.1

20.2.2

20. 3 OTHER BACTERIA:

20.3.1

20.3 .2

21. PLANKTON: Phytoplankton, Zooplankton

21.1

21.2

22. BENTHIC INVERTEBRATES:

22.1

22.2

23. PERIPHYTON:

23.1

23.2

24. MACROPHYTES:

24.1

24.2

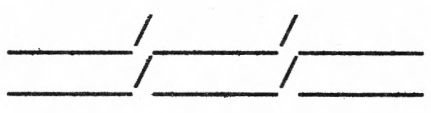

25. AQUATIC VERTEBRATES:

25.1

25.2

26. BIOASSAY:

26.1

26.2
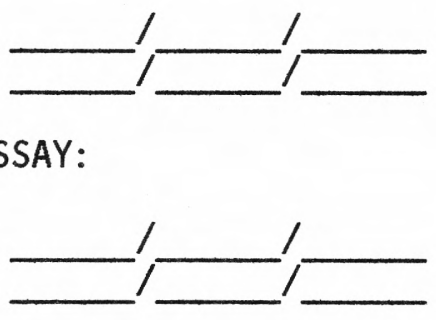

27. OTHER:

27.1

27.2

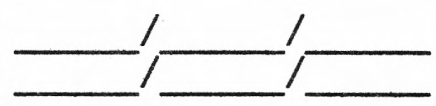


28. BIOLOGICAL LABORATORY AND QUALITY ASSURANCE:

: Used : Refer. : Split : Spiked : QA per- :None : Items :

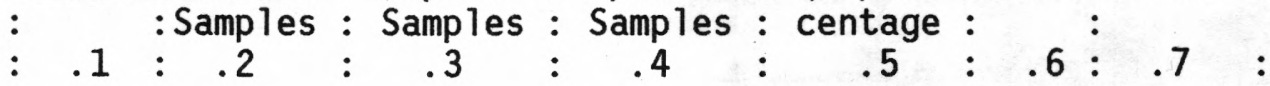

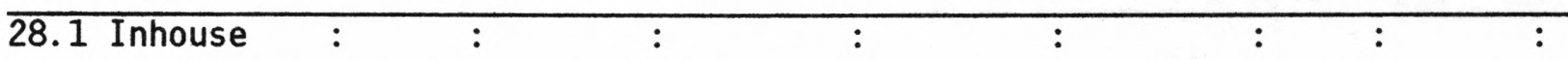

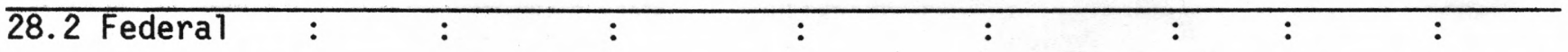

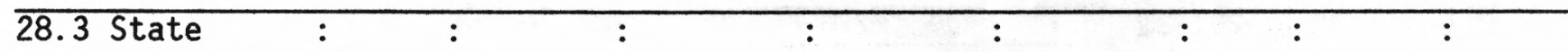

\begin{tabular}{llllllll}
\hline 28.4 County & $:$ & $:$ & $:$ & $:$ & $:$ & $:$ & $:$
\end{tabular}

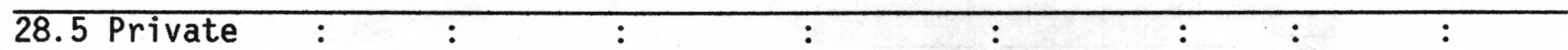

28.6 0ther

29.0 Sample Collection: Name

Address

Contact:

Phone

30.0 Sample Analysis: Name

Address

Contact:

Phone

V. SEDIMENT MEASUREMENTS

31. SUSPENDED SEDIMENT:

31.1

31.2

32. BED MATERIAL:

32.1

32.2

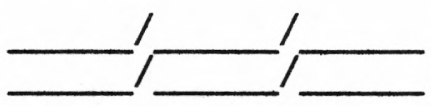


33. BED LOAD:

33.1

33.2

34. TOTAL LOAD:

34.1

34.2

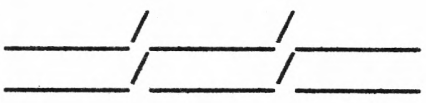

35. SEDIMENT LABORATORY AND QUALITY ASSURANCE:

$$
\begin{aligned}
& \text { : Used : Refer. : Split : Spiked : QA per- :None : Items : }
\end{aligned}
$$

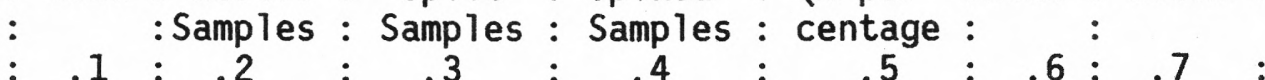

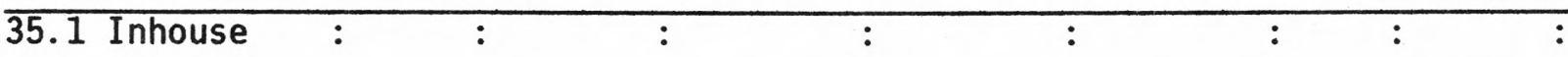

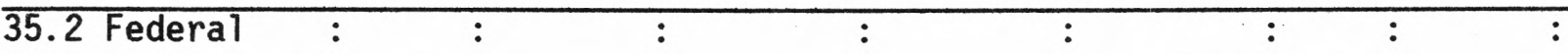

\begin{tabular}{llllll}
\hline 5.3 State & $:$ & $:$ & $:$ & $:$
\end{tabular}

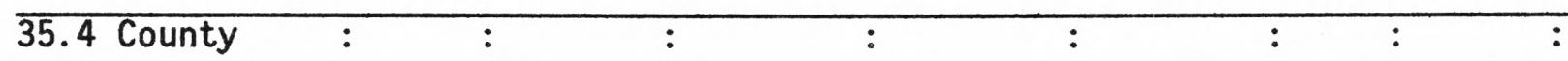

\begin{tabular}{|c|c|c|c|c|c|c|c|c|}
\hline 35.5 Private & : & $:$ & : & : & : & : & $:$ & $:$ \\
\hline 35.6 other & : & $:$ & : & : & : & : & : & : \\
\hline
\end{tabular}

36. 0 Sample Collection: Name

Address

Contact:

Phone

37. 0 Sample Analysis: Name

Address

Contact:

Phone 


\section{INDIVIDUAL COMPLETING FORM:}

Name:

Address:

Phone 
Water-Quality Monitoring Activities Questionnaire (Phase I) Instructions

Introduction:

The purpose of the questionnaire is to document, in a systematic way, the current quality-of-water data-collection programs within each State. It is intended to be a general summary of these programs and not a detailed listing of all data-collection sites, sampling frequencies, or measurements made. Because it is a general summary, there will be instances when only the major or most frequent measurements made at most of the sites in a program will be listed and the specific or unusual measurements may not be reported.

The questionnaire is divided into five major sections:

I. Agency and Program Information

II. Physical/Field Measurements

III. Chemical Measurements

IV. Biological Measurements

V. Sediment Measurements

The questionnaire should be filled out for the 1984 fiscal year program. A separate questionnaire should be filled out for each major water-quality program conducted by each agency.

I. Agency and Program Information.

1. Agency Name: Give full agency/company name, including department if appropriate.

(Example: Department of the Interior, U.S. Geological Survey)

2. Division: Give division and/or section name.

(Example: Water Resources Division/Mid-Atlantic District/ Virginia State Office)

3. Address: Give complete mailing address, including State and zip code.

4. Phone: Give complete phone number, including area code; give FTS number and commercial number, if available.

5. Contact Name: Give name, title, and phone number (if different than agency's number) for individual from whom the information on the questionnaire was received. 
6. Agency.

6.1 Agency Type: Circle type of agency.

6.2 Area of Responsibility: Circle the number of the word which best describes the area of responsibility for the office in number 2, above.

\subsection{PROGRAM:}

7.1 Type: Circle .1 or .2 for the word which best describes the type of program being described and .3 or .4 for surface- or ground-water programs.

7.2 Program Name: Give full name (plus acronym, if any). (Example: National Stream-Quality Accounting Network, NASQAN)

7.3 Give the name of study, if appropriate.

7.4 Number of Sites: Give total number of sites in the program at which quality of water data are collected. If program is multi-State, only include sites that are within the State and that are operated by the office listed in number 2 , above.

7. 5 Length of Program: Give total number of years or months for the program, and give month and year of start and end dates.

(Example: 12 years Start 10/72 End 9/84)

If program is an ongoing program with no expected end date, enter "9/99" for ending date and number of years to date.

7.6 a \& b Self-explanatory.

7.7 Program objectives: Circle the numbers of all the phrases that describe the objective(s) of the program.

7.8 Geographic Area: Circle the number of the word that best describes the areal extent of the program or study within the State. If program or study is part of a larger, multi-State program, include this fact in section 8.4.

7.9 Drainage Basin; Circle number of any of the drainage basins included in the sample. Cirle .5 if all drainage basins in State are included.

7.10 Sampling Locations: Check the category that best describes how sampling locations are identified. 
7.11 Data Availability: Circle the number of word that best describes the availability of the data. "Not available" means the data were proprietary or classified and not available to personnel outside the agency or company; "restricted" means the data were available to some agencies, but not available to the general public or that restrictions exist on its publication. "Unrestricted" means data that have no restrictions as to their availability or publication.

7.12 Surface Water: For surface-water-quality studies, check whether or not flow data are available. If "yes," note the type of data available.

7.13 Ground Water: Check yes or no, as appropriate.

\section{0 Support:}

8.1 Cooperator(s): List all agencies that supply services and/or funding for the program.

8.2 Funding: List the appropriate total amount of funds expended on the quality-of-water part of the program or study. If services are supplied as part of the funding, estimate the dollar value of these services.

8.3 Funding source(s): Give approximate percentage(s) of funds in section 8.2 that come from these sources.

(Example: .150 Federal and .250 State would be a 50-50 cooperative project between a Federal and a State agency.)

8.4 Comments: Include any additional information on the problem, scope, and objectives of the program or study not reported in section 7. If appropriate, include a short historical summary of the project, describing the types of data that have been collected in the past, the fluctuations in the size of the program over the years, and what types of analyses and interpretations of the data have been made.

8.5 References: Note any reports or series of reports describing the study and results, including reports in which the data have been published and/or interpretated. 
II. -V. Measurements

1. Each measurement subcategory has several lines in the format of "___ _ _ _ _ These lines are called sampling program lines (STL). If additional lines are needed, add the needed lines under those listed on the form and number them accordingly. the sampling program lines are filled out as follows: (See

Example 1)

The SPL has three parts -- A, B, and C -- and is formated as:

Part $A$ xxa

$$
\underset{\text { yy }}{\text { Part B }}
$$

Part C bc

Part A contains information on the number and type of site (a site is the location of sample collection). It is formated as:

$x x a$, where $x x$ is the number of sites and $a$ is a code for the type of sites.

$$
\begin{aligned}
& \text { Site type codes are: } \\
& \begin{aligned}
\mathbf{s} & =\text { surface water } \\
\mathrm{g} & =\text { ground water } \\
\mathrm{p} & =\text { precipitation } \\
\mathrm{e} & =\text { effluent }
\end{aligned}
\end{aligned}
$$

Part B contains information on the frequency of measurements and is formated as:

yy, where yy is the number of samples per year per site.

(Note: If samples are collected or an event basis, estimate the approximate number of samples to be taken during the year.)

Part $\mathrm{C}$ contains information on the storage and publication of the measurements and is formated as:

bc, where b and c are storage and publication codes. If more than one storage code fits the data, list the most appropriate code.

(Example: Data stored in WATSTORE would also be machine readable and might also be in STORET. However, WATSTORE is the primary storage file for the data; therefore, the code "w" would be used) 
Publication codes:

$$
\begin{aligned}
& \mathrm{p}=\text { published } \\
& \mathrm{n}=\text { not published }
\end{aligned}
$$

Storage codes:

$$
\begin{aligned}
& h=\text { hard copy, in agency files } \\
& \mathrm{m}=\text { machine readable/automated } \\
& \mathrm{w}=\text { WATSTORE } \\
& \mathrm{s}=\text { STORET } \\
& \mathrm{o}=\text { other ADP file }
\end{aligned}
$$

2. Items 9-12: Circle the measurements made and fill in the SPL. If more than one SPL is required and three or less measurements are made at only some of the sites, list these measurements after the appropriate SPL. (See Example 2, item 11.2.)

3. Item 13: If the same SPL would be appropriate for all categories in 13.1-13.3, then use that SPL for 13.0 and do not complete 13.1-13.3. If all measurements are not made in 13.1-13.3, complete the individual sections as appropriate.

4. Items 13.2, 13.3, 14-16: If the analysis is for specific compounds or pesticides, such as dioxin or DDT, list these compounds after the corresponding SPL. If a general analysis is done to determine what compounds are present, do not list findings, only fill out SPL.

5. Items 17-19, 28-30, 35-37: These items refer to the Chemical (17), Biological (28), and Sediment (35) support organizations and laboratories used and the quality-assurance programs associated with them.

Place a check ( ) in column .1 (used) for each type of laboratory used. If more than one type of laboratory is used, indicate the type of measurements made by each type laboratory by placing the questionnaire item number in column .7 for each type measurement made by each type laboratory. (See Example 3.)

Place a check ( ) in columns .2, .3, and(or) .4 or .6, where appropriate for each type laboratory.

Enter the percentage of work for quality assurance in column .5 ( 1 ist as percent). Example, if 1 out of every 10 samples are split, then the percentage for quality assurance would be 10 percent, and "10" would be placed in column .5.

6. Items 20-27 and 31-34: Fill in the appropriate SPL's for the type of biological and(or) sediment measurements made under the program. Provide names and addresses of support organization undertaking the sampling and of the laboratory carrying out the analyses. Provide the name and title of the person most familiar with the procedures used for this study. 
Example-1

A sample SPL would be:

$10 \mathrm{~s} / 12 / \mathrm{pw}$

this would be: $\quad 10$ surface-water sites

12 samples are collected per year, and

the data are published and stored in WATSTORE

\section{Example-2}

III. Chemical Measurements

10. Major inorganics:

Ca, Mg, Na, K, $\mathrm{F}, \mathrm{SO}, \mathrm{N03}$, Acidity/Alkalinity, $\mathrm{pH}, \mathrm{SC}$,

$10.1 \frac{10 \mathrm{~s} / 12 / \mathrm{pw}}{\log / 12 / \mathrm{pw}}$

11. Trace Elements:

As, $\mathrm{Ba}, \mathrm{Be}, \mathrm{Cd}, \mathrm{Co}, \mathrm{Cr}, \mathrm{Cu}, \mathrm{Fe}, \mathrm{Hg}, \mathrm{Li}, \mathrm{Mn}, \mathrm{Mo}, \mathrm{Pb}, \mathrm{Se}, \mathrm{Sr}, \mathrm{V}, \mathrm{Zn}$,

11.1

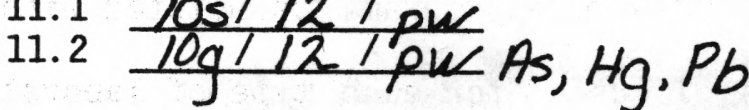

12. Nutrients:

Nitrogen forms; Phosphorus Forms

12.1

12.2

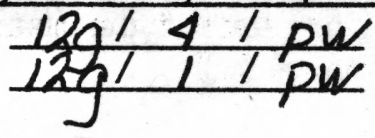

Notes

10. Both the surface-water and ground-water sites have basically the same measurements made; therefore, only the sampling program lines are filled out and the measurements have been circled.

11. All the trace elements listed are sampled at the surface-water sites (1ine 11.1) but only $\mathrm{As}, \mathrm{Hg}$, and $\mathrm{Pb}$ are measured at the ground-water sites ( 1 ine 11.2).

12. All the nutrients listed are measured and two different frequencies are used. This program would have a total of 48 ground-water stations, 12 sampled quarterly and 36 sampled yearly. 
Example-3

17. CHEMICAL LABORATORY AND QUALITY ASSURANCE:

\begin{tabular}{|c|c|c|c|c|c|c|c|c|c|}
\hline & $\begin{array}{cc}: & \text { Used } \\
: & \\
: & .1\end{array}$ & $\begin{array}{l}: \text { Refer. } \\
: \text { Samples } \\
: \quad .2\end{array}$ & $\begin{array}{cc}: & \text { Split } \\
: & \text { Samples } \\
: & .3\end{array}$ & $\begin{array}{cc}: & \text { Spiked } \\
: & \text { Samples } \\
: & .4\end{array}$ & : & $\begin{array}{c}\text { QA per- } \\
\text { centage } \\
.5\end{array}$ & $\begin{array}{ll} & \text { None } \\
: & \\
: & .6\end{array}$ & $\begin{array}{l}: \\
: \\
:\end{array}$ & $\begin{array}{c}\text { Items } \\
.7\end{array}$ \\
\hline 17.1 Inhouse & $:$ & : & $:$ & $:$ & : & & $\div$ & $:$ & \\
\hline 17.2 Federal & $: 12$ & : & $:$ & $:$ & : & & $:$ & $:$ & \\
\hline 17.3 State & : & : & : & $:$ & $:$ & & : & $:$ & \\
\hline 17.4 County & : & : & : & : & $:$ & & : & $:$ & \\
\hline$\overline{17.5 \text { Private }}$ & $: 14$ & : & $:$ & : & : & & $:$ & $:$ & \\
\hline 17.6 other & : & : & $:$ & : & : & ? & $:$ & $:$ & \\
\hline
\end{tabular}

In this example, the agency uses a Federal laboratory to have its nutrient samples analyzed and a private laboratory for its radiochemical analyses. 
Table 7.--organizations with water-quality data-collection programs active in Colorado during 1984 and the property and constituent groups for which data are reported [S, surface-water-quality analyses; G, ground-water-quality analyses; --, no data]

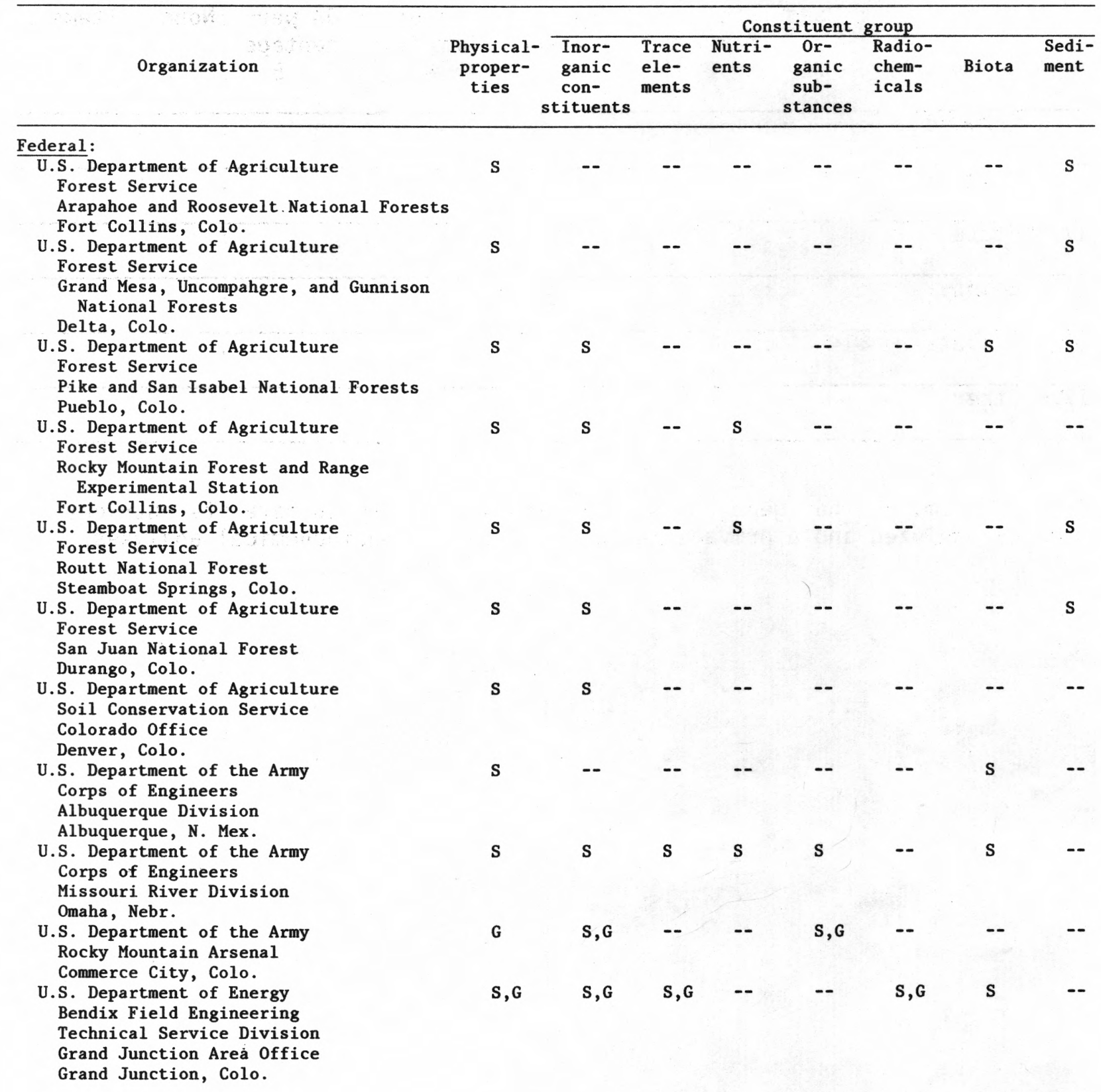


Table 7.--organizations with water-quality data-collection programs active in Colorado during 1984 and the property and constituent groups for which data are reported--Continued

\begin{tabular}{|c|c|c|c|c|c|c|c|c|}
\hline \multirow[b]{2}{*}{ Organization } & \multirow[b]{2}{*}{$\begin{array}{l}\text { Physical- } \\
\text { proper- } \\
\text { ties }\end{array}$} & \multicolumn{7}{|c|}{ Constituent group } \\
\hline & & $\begin{array}{l}\text { Inor- } \\
\text { ganic } \\
\text { con- } \\
\text { stituents }\end{array}$ & $\begin{array}{l}\text { Trace } \\
\text { ele- } \\
\text { ments }\end{array}$ & $\begin{array}{l}\text { Nutri- } \\
\text { ents }\end{array}$ & $\begin{array}{l}\text { Or- } \\
\text { ganic } \\
\text { sub- } \\
\text { stances }\end{array}$ & $\begin{array}{l}\text { Radio- } \\
\text { chem- } \\
\text { icals }\end{array}$ & Biota & $\begin{array}{l}\text { Sedi- } \\
\text { ment }\end{array}$ \\
\hline \multicolumn{9}{|l|}{ Federal--Continued: } \\
\hline $\begin{array}{l}\text { U.S. Department of Energy } \\
\text { Uranium Mill Tailings Project } \\
\text { Jacobs Engineering } \\
\text { Albuquerque, N. Mex. }\end{array}$ & G & G & G & -- & G & G & -- & -- \\
\hline $\begin{array}{l}\text { U.S. Department of the Interior } \\
\text { Bureau of Land Management } \\
\text { Canon City District } \\
\text { Canon City, Colo. }\end{array}$ & $\mathrm{S}$ & $\mathrm{S}$ & -- & $\mathrm{S}$ & -- & -- & $\mathrm{S}$ & -- \\
\hline $\begin{array}{l}\text { U.S. Department of the Interior } \\
\text { Bureau of Land Management } \\
\text { Division of Lands and Renewable Resources } \\
\text { Grand Junction District Office } \\
\text { Grand Junction, Colo. }\end{array}$ & es & S & $\mathrm{S}$ & -- & -- & -- & -- & -- \\
\hline $\begin{array}{l}\text { U.S. Department of the Interior } \\
\text { Bureau of Land Management } \\
\text { Montrose District } \\
\text { Montrose, Colo. }\end{array}$ & -- & $\mathrm{s}$ & s & -- & -- & -- & -- & -- \\
\hline $\begin{array}{l}\text { U.S. Department of the Interior } \\
\text { Bureau of Land Management } \\
\text { Oil Shale Project Office } \\
\text { Grand Junction, Colo. }\end{array}$ & G & G & G & G & G & -- & -- & -- \\
\hline $\begin{array}{l}\text { U.S. Department of the Interior } \\
\text { Bureau of Reclamation } \\
\text { Operations and Maintenance Division } \\
\text { Alamosa, Colo. }\end{array}$ & G & G & G & -- & G & -- & G & -- \\
\hline $\begin{array}{l}\text { U.S. Department of the Interior } \\
\text { Bureau of Reclamation Planning Division } \\
\text { Upper Colorado Region } \\
\text { Salt Lake City, Utah. }\end{array}$ & $S, G$ & $S, G$ & $\mathrm{~S}$ & s & -- & -- & -- & -- \\
\hline $\begin{array}{l}\text { U.S. Department of the Interior } \\
\text { Geological Survey } \\
\text { Denver, Colo. }\end{array}$ & $S, G$ & $S, G$ & $S, G$ & $S, G$ & $S, G$ & $S, G$ & $\mathrm{~S}, \mathrm{G}$ & $\mathrm{S}$ \\
\hline $\begin{array}{l}\text { U.S. Department of the Interior } \\
\text { National Park Service } \\
\text { Water Resources Field Support Laboratory } \\
\text { Fort Collins, Colo. }\end{array}$ & $y$ & $\mathrm{~S}$ & $\mathrm{~S}$ & $\mathrm{~s}$ & $\mathrm{~S}$ & $\mathrm{~S}$ & $\mathrm{~S}$ & $\mathrm{~S}$ \\
\hline $\begin{array}{l}\text { U.S. Department of the Interior } \\
\text { Office of Surface Mining } \\
\text { Albuquerque, N. Mex. }\end{array}$ & -- & $\mathrm{S}$ & $\mathrm{S}$ & -- & -- & -- & -- & $\mathrm{S}$ \\
\hline $\begin{array}{l}\text { U.S. Environmental Protection } \\
\text { Agency, Region VIII } \\
\text { Air and Waste Management Division } \\
\text { Denver, Colo. }\end{array}$ & -- & G & G & -- & G & -- & -- & -- \\
\hline $\begin{array}{l}\text { U.S. Environmental Protection } \\
\text { Agency, Region VIII } \\
\text { Environmental Services Division } \\
\text { Denver, Colo. }\end{array}$ & $S$ & $\mathrm{~S}$ & $\mathrm{~S}$ & $\mathrm{~S}$ & $\mathrm{~S}$ & $\mathrm{~S}$ & $\mathrm{~S}$ & -- \\
\hline $\begin{array}{l}\text { U.S. Environmental Protection } \\
\text { Agency, Region VIII }\end{array}$ & $S, G$ & $S, G$ & $\mathrm{~S}, \mathrm{G}$ & -- & $S, G$ & -- & -- & -- \\
\hline
\end{tabular}

Water Management Division

Denver, Colo. 
Table 7.--organizations with water-quality data-collection programs active in Colorado during 1984 and the property and constituent groups for which data are reported--Continued

\begin{tabular}{|c|c|c|c|c|c|c|c|c|}
\hline \multirow[b]{2}{*}{ Organization } & \multirow[b]{2}{*}{$\begin{array}{l}\text { Physical- } \\
\text { proper- } \\
\text { ties }\end{array}$} & \multicolumn{7}{|c|}{ Constituent group } \\
\hline & & $\begin{array}{l}\text { Inor- } \\
\text { ganic } \\
\text { con- } \\
\text { stituents }\end{array}$ & $\begin{array}{l}\text { Trace } \\
\text { ele- } \\
\text { ments }\end{array}$ & $\begin{array}{l}\text { Nutri- } \\
\text { ents }\end{array}$ & $\begin{array}{l}\text { Or- } \\
\text { ganic } \\
\text { sub- } \\
\text { stances }\end{array}$ & $\begin{array}{l}\text { Radio- } \\
\text { chem- } \\
\text { icals }\end{array}$ & Biota & $\begin{array}{l}\text { Sedi- } \\
\text { ment }\end{array}$ \\
\hline \multicolumn{9}{|l|}{ State: } \\
\hline $\begin{array}{l}\text { Colorado Department of Health } \\
\text { Environmental Health Division } \\
\text { Denver, Colo. }\end{array}$ & $\mathrm{S}$ & $S, G$ & $S, G$ & -- & $\mathbf{S}$ & -- & -- & -- \\
\hline $\begin{array}{l}\text { Colorado Department of Health } \\
\text { Environmental Services Division } \\
\text { Denver, Colo. }\end{array}$ & -- & -- & -- & -- & -- & -- & $S, G$ & S \\
\hline $\begin{array}{l}\text { Colorado Department of Health } \\
\text { Radiation Control Division } \\
\text { Denver, Colo. }\end{array}$ & -- & $S, G$ & $S, G$ & -- & -- & $S, G$ & -- & -- \\
\hline $\begin{array}{l}\text { Colorado Department of Health } \\
\text { Waste Management Division } \\
\text { Denver, Colo. }\end{array}$ & -- & G & G & -- & G & -- & -- & -- \\
\hline $\begin{array}{l}\text { Colorado Department of Health } \\
\text { Water Quality Control Division } \\
\text { Denver, Colo. }\end{array}$ & S & $S, G$ & $\mathrm{~S}$ & $S, G$ & $\mathbf{S}$ & $\mathbf{S}$ & $\mathbf{S}$ & -- \\
\hline $\begin{array}{l}\text { Colorado Department of Highways } \\
\text { Division of Transportation Planning } \\
\text { Denver, Colo. }\end{array}$ & $\mathbf{S}$ & $\mathbf{S}$ & $\mathbf{S}$ & -- & -- & -- & -- & S \\
\hline $\begin{array}{l}\text { Colorado Department of Natural Resources } \\
\text { Division of Mined Land Reclamation } \\
\text { Denver, Colo. }\end{array}$ & $S, G$ & $S, G$ & $\mathrm{~S}, \mathrm{G}$ & $S, G$ & $S, G$ & $S, G$ & -- & $\mathbf{S}$ \\
\hline \multicolumn{9}{|l|}{ Regional--Intrastate: } \\
\hline $\begin{array}{l}\text { Colorado River Water Conservation District } \\
\text { Glenwood Springs, Colo. }\end{array}$ & -- & $\mathbf{S}$ & $\mathbf{S}$ & $\mathbf{S}$ & -- & -- & -- & $\mathbf{S}$ \\
\hline $\begin{array}{l}\text { Denver Water Department } \\
\text { Wastewater Management Division } \\
\text { Quality Control Laboratory } \\
\text { Denver, Colo. }\end{array}$ & S & $\mathrm{S}$ & $\mathbf{S}$ & $\mathbf{s}$ & -- & -- & $\mathbf{S}$ & -- \\
\hline $\begin{array}{l}\text { Metropolitan Denver Sewage Disposal } \\
\text { District Number } 1 \\
\text { Department of Laboratory Services } \\
\text { Denver, Colo. }\end{array}$ & $\mathbf{s}$ & $\mathbf{S}$ & $\mathbf{S}$ & $\mathbf{S}$ & $\mathbf{s}$ & -- & $\mathbf{S}$ & -- \\
\hline $\begin{array}{l}\text { Project Seven Water Authority } \\
\text { Montrose, Colo. }\end{array}$ & S & $\mathbf{S}$ & S & $\mathbf{S}$ & -- & -- & -- & -- \\
\hline \multicolumn{9}{|l|}{ Local: } \\
\hline $\begin{array}{l}\text { Arvada, City of } \\
\text { Department of Public Works } \\
\text { Utilities Division. }\end{array}$ & -- & -- & -- & $\mathbf{S}$ & -- & -- & -- & -- \\
\hline $\begin{array}{l}\text { Boulder, City of } \\
\text { Department of Public Works } \\
\text { Utilities Division. }\end{array}$ & $\mathrm{S}$ & S & -- & -- & -- & -- & -- & -- \\
\hline $\begin{array}{l}\text { Brighton, City of } \\
\text { Utility Department } \\
\text { Water Division. }\end{array}$ & -- & G & -- & -- & G & -- & -- & -- \\
\hline $\begin{array}{l}\text { Broomfield, City of } \\
\text { Department of Public Works } \\
\text { Environmental Division. }\end{array}$ & $\mathrm{S}$ & $\mathbf{S}$ & -- & $\mathbf{s}$ & -- & $\mathbf{S}$ & $\mathbf{S}$ & -- \\
\hline $\begin{array}{l}\text { Colorado City, City of } \\
\text { Water and Sanitation District. }\end{array}$ & s & $\mathbf{S}$ & $\mathrm{S}$ & -- & $\mathbf{S}$ & -- & $\mathbf{S}$ & $\mathbf{S}$ \\
\hline
\end{tabular}


Table 7.--organizations with water-quality data-collection programs active in Colorado during 1984 and the property and constituent groups for which data are reported--Continued

\begin{tabular}{|c|c|c|c|c|c|c|c|c|}
\hline \multirow[b]{2}{*}{ Organization } & \multirow[b]{2}{*}{$\begin{array}{l}\text { Physical- } \\
\text { proper- } \\
\text { ties }\end{array}$} & \multicolumn{7}{|c|}{ Constituent group } \\
\hline & & $\begin{array}{l}\text { Inor- } \\
\text { ganic } \\
\text { con- } \\
\text { stituents }\end{array}$ & $\begin{array}{l}\text { Trace } \\
\text { ele- } \\
\text { ments }\end{array}$ & $\begin{array}{l}\text { Nutri- } \\
\text { ents }\end{array}$ & $\begin{array}{l}\text { Or- } \\
\text { ganic } \\
\text { sub- } \\
\text { stances }\end{array}$ & $\begin{array}{l}\text { Radio- } \\
\text { chem- } \\
\text { icals }\end{array}$ & Biota & $\begin{array}{l}\text { Sedi- } \\
\text { ment }\end{array}$ \\
\hline \multicolumn{9}{|l|}{ Local--Continued: } \\
\hline $\begin{array}{l}\text { Colorado Springs, City of } \\
\text { Department of Public Utilities } \\
\text { Water Resources and Treatment Division. }\end{array}$ & $\mathrm{S}$ & $\mathrm{S}, \mathrm{G}$ & $S, G$ & $S, G$ & $\mathrm{~S}$ & -- & $S, G$ & -- \\
\hline $\begin{array}{l}\text { Denver, City and County of } \\
\text { Department of Health and Hospitals } \\
\text { Environmental Health Service. }\end{array}$ & -- & $\mathrm{s}$ & $\mathrm{s}$ & $\mathrm{s}$ & $\mathrm{s}$ & -- & $\mathrm{s}$ & -- \\
\hline $\begin{array}{l}\text { Florence, City of } \\
\text { Regional Water System. }\end{array}$ & $\mathbf{S}$ & -- & -- & -- & -- & -- & $\mathbf{S}$ & -- \\
\hline $\begin{array}{l}\text { Fort Collins, City of } \\
\text { Utilities Department } \\
\text { Water Division. }\end{array}$ & s & $\mathrm{S}$ & $\mathrm{S}$ & $\mathbf{S}$ & $\mathrm{S}$ & -- & $\mathbf{S}$ & -- \\
\hline $\begin{array}{l}\text { Glendale, City of } \\
\text { Department of Public Works. }\end{array}$ & G & G & G & -- & G & G & G & -- \\
\hline $\begin{array}{l}\text { Golden, City of } \\
\text { Water Treatment Department } \\
\text { Water Quality Laboratory. }\end{array}$ & -- & -- & S & -- & -- & -- & -- & -- \\
\hline $\begin{array}{l}\text { Granby, City of } \\
\text { Sanitation District. }\end{array}$ & S & S & -- & $\mathbf{S}$ & $\mathrm{S}$ & -- & $\mathbf{S}$ & -- \\
\hline $\begin{array}{l}\text { Greeley, City of } \\
\text { Department of Public Works } \\
\text { Water and Sewer Division. }\end{array}$ & S & $\mathbf{S}$ & S & S & $\mathbf{S}$ & -- & $\mathrm{S}$ & -- \\
\hline $\begin{array}{l}\text { Longmont, City of } \\
\text { Department of Sewer Utilities } \\
\text { Wastewater Treatment Division. }\end{array}$ & s & $\mathrm{S}$ & S & S & -- & S & $\mathrm{s}$ & -- \\
\hline $\begin{array}{l}\text { Louisville, City of } \\
\text { Department of Water Treatment. }\end{array}$ & s & $\mathbf{S}$ & -- & -- & -- & -- & -- & $\mathbf{S}$ \\
\hline $\begin{array}{l}\text { Loveland, City of } \\
\text { Planning, Engineering, and Building } \\
\text { Department }\end{array}$ & S & $\mathrm{S}$ & $\mathrm{S}$ & S & $\mathrm{s}$ & -- & S & -- \\
\hline $\begin{array}{l}\text { Sewer and Sanitation Division. } \\
\text { Loveland, City of } \\
\text { Water Administration Department } \\
\text { Water Resources Division. }\end{array}$ & -- & -- & -- & -- & -- & -- & $\mathrm{S}$ & -- \\
\hline $\begin{array}{l}\text { Northglenn, City of } \\
\text { Department of Natural Resources } \\
\text { Water Quality Laboratory Division. }\end{array}$ & G & G & G & G & G & -- & G & -- \\
\hline $\begin{array}{l}\text { Pueblo, City of } \\
\text { Board of Water Works. }\end{array}$ & S & $\mathrm{S}$ & $\mathrm{S}$ & S & $\mathrm{s}$ & -- & $\mathbf{S}$ & $\mathrm{S}$ \\
\hline $\begin{array}{l}\text { Thornton, City of } \\
\text { Utilities, Water Quality Division. }\end{array}$ & S & $\mathbf{S}$ & $\mathbf{S}$ & $\mathbf{S}$ & $\mathbf{S}$ & -- & $\mathbf{S}$ & -- \\
\hline $\begin{array}{l}\text { Westminster, City of } \\
\text { Department of Public Works } \\
\text { Semper Water Plant. }\end{array}$ & S & $\mathrm{S}$ & $\mathrm{S}$ & S & $\mathrm{S}$ & -- & $\mathbf{S}$ & -- \\
\hline $\begin{array}{l}\text { Morgan County Water Quality District } \\
\text { Fort Morgan, Colo. }\end{array}$ & -- & G & -- & $-\infty$ & G & -- & -- & -- \\
\hline $\begin{array}{l}\text { Northwest Council of Governments } \\
\text { Summit County Water Quality Committee } \\
\text { Frisco, Colo. }\end{array}$ & $\mathrm{S}$ & S & -- & $\mathbf{S}$ & -- & -- & $\mathbf{S}$ & -- \\
\hline $\begin{array}{l}\text { Security Water and Sanitation District } \\
\text { Colorado Springs, Colo. }\end{array}$ & -- & G & -- & -- & -- & -- & -- & -- \\
\hline
\end{tabular}


Table 7.--organizations with water-quality data-collection programs active in Colorado during 1984 and the property and constituent groups for which data are reported--Continued

\begin{tabular}{|c|c|c|c|c|c|c|c|c|}
\hline \multirow[b]{2}{*}{ Organization } & \multirow[b]{2}{*}{$\begin{array}{l}\text { Physical- } \\
\text { proper- } \\
\text { ties }\end{array}$} & \multicolumn{7}{|c|}{ Constituent group } \\
\hline & & $\begin{array}{l}\text { Inor- } \\
\text { ganic } \\
\text { con- } \\
\text { stituents }\end{array}$ & $\begin{array}{l}\text { Trace } \\
\text { ele- } \\
\text { ments }\end{array}$ & $\begin{array}{l}\text { Nutri- } \\
\text { ents }\end{array}$ & $\begin{array}{l}\text { Or- } \\
\text { ganic } \\
\text { sub- } \\
\text { stances }\end{array}$ & $\begin{array}{l}\text { Radio- } \\
\text { chem- } \\
\text { icals }\end{array}$ & Biota & $\begin{array}{l}\text { Sedi- } \\
\text { ment }\end{array}$ \\
\hline \multicolumn{9}{|l|}{ Local--Continued: } \\
\hline $\begin{array}{l}\text { South Adams Water and Sanitation District } \\
\text { Commerce City, Colo. }\end{array}$ & -- & G & G & G & G & G & -- & -- \\
\hline $\begin{array}{l}\text { Weld County Health Department } \\
\text { Health Protection Service } \\
\text { Greeley, Colo. }\end{array}$ & G & G & G & G & G & -- & G & -- \\
\hline \multicolumn{9}{|l|}{ Academic institutions: } \\
\hline $\begin{array}{l}\text { University of Colorado--Boulder } \\
\text { Department of Environmental, Population, } \\
\text { and Organismic Biology } \\
\text { Boulder, Colo. }\end{array}$ & , & $\mathbf{S}$ & -- & -- & -- & -- & -- & $\mathrm{S}$ \\
\hline $\begin{array}{l}\text { University of Colorado--Denver } \\
\text { Center for Environmental Sciences } \\
\text { Denver, Colo. }\end{array}$ & S & S & $\mathbf{S}$ & $\mathbf{S}$ & -- & -- & -- & -- \\
\hline $\begin{array}{l}\text { Western State College } \\
\text { Biology Department } \\
\text { Gunnison, Colo. }\end{array}$ & $S, G$ & $\mathrm{~S}, \mathrm{G}$ & $S, G$ & $\mathrm{~S}, \mathrm{G}$ & -- & -- & $\mathrm{S}$ & -- \\
\hline
\end{tabular}


Table 8.--Organizations with water-quality data-collection programs active in ohio during 1984 and the property and constituent groups for which data are reported

[S, surface-water analyses; G, ground-water analyses; --, no data]

\begin{tabular}{|c|c|c|c|c|c|c|c|c|}
\hline \multirow[b]{2}{*}{ Organization } & \multirow[b]{2}{*}{$\begin{array}{l}\text { Physical- } \\
\text { proper- } \\
\text { ties }\end{array}$} & \multicolumn{7}{|c|}{ Constituent group } \\
\hline & & $\begin{array}{l}\text { Inor- } \\
\text { ganic } \\
\text { con- } \\
\text { stituents }\end{array}$ & $\begin{array}{l}\text { Trace } \\
\text { ele- } \\
\text { ments }\end{array}$ & $\begin{array}{l}\text { Nutri- } \\
\text { ents }\end{array}$ & $\begin{array}{l}\text { Or- } \\
\text { ganic } \\
\text { sub- } \\
\text { stances }\end{array}$ & $\begin{array}{l}\text { Radio- } \\
\text { chem- } \\
\text { icals }\end{array}$ & Biota & $\begin{array}{l}\text { Sedi- } \\
\text { ment }\end{array}$ \\
\hline \multicolumn{9}{|l|}{ Federal: } \\
\hline $\begin{array}{l}\text { U.S. Department of Agriculture } \\
\text { Agricultural Research Service } \\
\text { Coshocton, Ohio. }\end{array}$ & $\mathrm{S}$ & $\mathrm{S}$ & $\mathrm{s}$ & $\mathrm{s}$ & $\mathrm{S}$ & -- & -- & -- \\
\hline $\begin{array}{l}\text { U.S. Department of Agriculture } \\
\text { Forest. Service } \\
\text { Wayne-Hoosier National Forest } \\
\text { Bedford, Ind. }\end{array}$ & $\mathrm{S}$ & $\mathrm{S}$ & -- & $\mathrm{S}$ & -- & -- & $\mathrm{S}$ & -- \\
\hline $\begin{array}{l}\text { U.S. Department of the Army } \\
\text { Corps of Engineers } \\
\text { Ohio River Division } \\
\text { Huntington District } \\
\text { Huntington, W. Va. }\end{array}$ & $\mathrm{S}$ & S & S & $\mathrm{S}$ & -- & -- & -- & -- \\
\hline $\begin{array}{l}\text { U.S. Department of the Army } \\
\text { Corps of Engineers } \\
\text { Ohio River Division } \\
\text { Louisville District } \\
\text { Louisville, Ky. }\end{array}$ & $\mathrm{S}$ & $\mathrm{s}$ & s & s & -- & -- & $\mathrm{S}$ & -- \\
\hline $\begin{array}{l}\text { U.S. Department of the Army } \\
\text { Corps of Engineers } \\
\text { Ohio River Division } \\
\text { Pittsburgh District } \\
\text { Pittsburgh, Pa. }\end{array}$ & $\mathrm{S}$ & $\mathrm{S}$ & $\mathrm{s}$ & -- & S & -- & -- & -- \\
\hline $\begin{array}{l}\text { U.S. Department of Defense } \\
\text { Wright Patterson Air Force Base } \\
\text { Dayton, Ohio. }\end{array}$ & $S, G$ & G & $S, G$ & -- & $S, G$ & -- & -- & -- \\
\hline $\begin{array}{l}\text { U.S. Department of Energy } \\
\text { Dayton Area Office }\end{array}$ & -- & -- & -- & -- & -- & $S, G$ & -- & $\mathrm{S}$ \\
\hline $\begin{array}{l}\text { Miamisburg, Ohio. } \\
\text { U.S. Department of the Interior } \\
\text { Geological Survey } \\
\text { Water Resources Division } \\
\text { Ohio District Office } \\
\text { Columbus, Ohio. }\end{array}$ & $S, G$ & $\mathrm{~S}, \mathrm{G}$ & $S, G$ & $S, G$ & S , G & $S, G$ & $\mathrm{~S}, \mathrm{G}$ & $S, G$ \\
\hline $\begin{array}{l}\text { U.S. Department of the Interior } \\
\text { National Park Service } \\
\text { Cuyahoga National Recreation Area } \\
\text { Brecksville, Ohio. }\end{array}$ & $\mathrm{S}$ & -- & -- & -- & -- & -- & $\mathrm{s}$ & -- \\
\hline $\begin{array}{l}\text { U.S. Department of the Interior } \\
\text { Bureau of Mines } \\
\text { Pittsburgh Research Center } \\
\text { Pittsburgh, Pa. }\end{array}$ & $S, G$ & $S, G$ & -- & -- & -- & -- & -- & -- \\
\hline $\begin{array}{l}\text { U.S. Environmental Protection } \\
\text { Agency } \\
\text { Office of Drinking Water } \\
\text { Cincinnati, Ohio. }\end{array}$ & G & G & G & -- & -- & G & -- & -- \\
\hline $\begin{array}{l}\text { U.S. Environmental Protection } \\
\text { Agency } \\
\text { Eastern District Office } \\
\text { Westlake, Ohio. }\end{array}$ & $\mathrm{S}$ & -- & $\mathrm{S}$ & -- & -- & -- & -- & -- \\
\hline
\end{tabular}


Table 8.--organizations with water-quality data-collection programs active in ohio during 1984 and the property and constituent groups for which data are reported--Continued

\begin{tabular}{|c|c|c|c|c|c|c|c|c|}
\hline \multirow[b]{2}{*}{ Organization } & \multirow[b]{2}{*}{$\begin{array}{l}\text { Physical- } \\
\text { proper- } \\
\text { ties }\end{array}$} & \multicolumn{7}{|c|}{ Constituent group } \\
\hline & & $\begin{array}{l}\text { Inor- } \\
\text { ganic } \\
\text { con- } \\
\text { stituents }\end{array}$ & $\begin{array}{l}\text { Trace } \\
\text { ele- } \\
\text { ments }\end{array}$ & $\begin{array}{l}\text { Nutri- } \\
\text { ents }\end{array}$ & $\begin{array}{l}\text { Or- } \\
\text { ganic } \\
\text { sub- } \\
\text { stances }\end{array}$ & $\begin{array}{l}\text { Radio- } \\
\text { chem- } \\
\text { icals }\end{array}$ & Biota & $\begin{array}{l}\text { Sedi- } \\
\text { ment }\end{array}$ \\
\hline \multicolumn{9}{|l|}{ State: } \\
\hline $\begin{array}{l}\text { Ohio Environmental Protection Agency } \\
\text { Columbus, Ohio. }\end{array}$ & $\mathrm{S}, \mathrm{G}$ & $S, G$ & $S, G$ & $\mathrm{~S}, \mathrm{G}$ & $S, G$ & S, G & $\mathbf{S}$ & $\mathbf{S}$ \\
\hline $\begin{array}{l}\text { Ohio Department of Health } \\
\text { Columbus, Ohio. }\end{array}$ & G & -- & -- & -- & -- & -- & G & -- \\
\hline $\begin{array}{l}\text { Ohio Department of Natural Resources } \\
\text { Columbus, Ohio. }\end{array}$ & $S, G$ & $S, G$ & $S, G$ & $\mathbf{s}$ & -- & -- & $\mathbf{S}$ & $\mathbf{S}$ \\
\hline $\begin{array}{l}\text { Ohio Department of Transportation } \\
\text { Columbus, Ohio. }\end{array}$ & $\mathbf{S}$ & $\mathbf{S}$ & -- & $\mathbf{s}$ & -- & -- & $\mathbf{S}$ & -- \\
\hline \multicolumn{9}{|l|}{ Regional--Interstate: } \\
\hline $\begin{array}{l}\text { Ohio River Valley Water Sanitation } \\
\text { Commission } \\
\text { Cincinnati, Ohio. }\end{array}$ & $\mathbf{S}$ & S & $\mathbf{S}$ & $\mathrm{s}$ & s & -- & $\mathbf{S}$ & -- \\
\hline \multicolumn{9}{|l|}{ Local: } \\
\hline $\begin{array}{l}\text { Akron, City of } \\
\text { Water Supply. }\end{array}$ & s & $\mathbf{S}$ & $\mathbf{S}$ & $s$ & $\mathbf{s}$ & -- & $\mathbf{S}$ & -- \\
\hline $\begin{array}{l}\text { Barberton, City of } \\
\text { Water Supply. }\end{array}$ & $\mathbf{S}$ & $\mathrm{S}$ & $\mathrm{S}$ & $\mathbf{s}$ & s & -- & $\mathbf{s}$ & -- \\
\hline $\begin{array}{l}\text { Bowling Green, City of } \\
\text { Water Department. }\end{array}$ & $\mathbf{S}$ & $\mathbf{S}$ & -- & -- & $\mathbf{S}$ & -- & -- & -- \\
\hline $\begin{array}{l}\text { Canton, City of } \\
\text { Water Division. }\end{array}$ & G & G & G & G & G & -- & G & -- \\
\hline $\begin{array}{l}\text { Cincinnati, City of } \\
\text { Waterworks. }\end{array}$ & $\mathrm{S}, \mathrm{G}$ & $S, G$ & $S, G$ & -- & $S, G$ & -- & -- & -- \\
\hline $\begin{array}{l}\text { Cleveland, City of } \\
\text { Water Division. }\end{array}$ & $\mathbf{S}$ & $\mathbf{S}$ & $\mathrm{S}$ & $\mathbf{S}$ & - & -- & -- & -- \\
\hline $\begin{array}{l}\text { Columbus, City of } \\
\text { Division of Water. }\end{array}$ & $S, G$ & $S, G$ & $\mathrm{~S}$ & $\mathbf{S}$ & $\mathbf{s}$ & -- & S, G & - \\
\hline $\begin{array}{l}\text { Cuyahoga Falls, City of } \\
\text { Division of Water }\end{array}$ & G & G & G & -- & -- & -- & -- & -- \\
\hline $\begin{array}{l}\text { Dayton, City of } \\
\text { Division of Water. }\end{array}$ & -- & -- & G & -- & G & -- & -- & -- \\
\hline $\begin{array}{l}\text { Elyria, City of } \\
\text { Division of Water. }\end{array}$ & $\mathrm{S}$ & $\mathrm{S}$ & -- & -- & -- & -- & $S$ & -- \\
\hline $\begin{array}{l}\text { Findlay, City of } \\
\text { Division of Water. }\end{array}$ & $\mathbf{S}$ & $\mathrm{s}$ & $\mathbf{S}$ & -- & -- & -- & -- & -- \\
\hline $\begin{array}{l}\text { Hamilton, City of } \\
\text { Division of Water. }\end{array}$ & G & G & G & G & -- & -- & G & -- \\
\hline $\begin{array}{l}\text { Kent, City of } \\
\text { Division of Water. }\end{array}$ & $\mathrm{G}$ & G & -- & -- & -- & -- & -- & -- \\
\hline $\begin{array}{l}\text { Lima, City of } \\
\text { Division of Water. }\end{array}$ & $\mathbf{S}$ & -- & -- & -- & -- & -- & -- & -- \\
\hline $\begin{array}{l}\text { Lorain, City of } \\
\text { Utilities Department. }\end{array}$ & $\mathbf{S}$ & $\mathrm{S}$ & $\mathbf{s}$ & $\mathrm{s}$ & -- & -- & - & -- \\
\hline $\begin{array}{l}\text { Newark, City of } \\
\text { Division of Water. }\end{array}$ & $\mathbf{S}$ & $\mathbf{S}$ & $\mathrm{S}$ & $\mathbf{S}$ & -- & -- & -- & -- \\
\hline $\begin{array}{l}\text { Springfield, City of } \\
\text { Division of Water. }\end{array}$ & G & G & G & -- & -- & -- & G & -- \\
\hline
\end{tabular}


Table 8.--Organizations with water-quality data-collection programs active in ohio during 1984 and the property and constituent groups for which data are reported--Continued

\begin{tabular}{|c|c|c|c|c|c|c|c|c|}
\hline \multirow[b]{2}{*}{ Organization } & \multirow[b]{2}{*}{$\begin{array}{l}\text { Physical- } \\
\text { proper- } \\
\text { ties }\end{array}$} & \multicolumn{7}{|c|}{ Constituent group } \\
\hline & & $\begin{array}{l}\text { Inor- } \\
\text { ganic } \\
\text { con- } \\
\text { stituents }\end{array}$ & $\begin{array}{l}\text { Trace } \\
\text { ele- } \\
\text { ments }\end{array}$ & $\begin{array}{l}\text { Nutri- } \\
\text { ents }\end{array}$ & $\begin{array}{l}\text { Or- } \\
\text { ganic } \\
\text { sub- } \\
\text { stances }\end{array}$ & $\begin{array}{l}\text { Radio- } \\
\text { chem- } \\
\text { icals }\end{array}$ & Biota & $\begin{array}{l}\text { Sedi- } \\
\text { ment }\end{array}$ \\
\hline \multicolumn{9}{|l|}{ Local--Continued: } \\
\hline $\begin{array}{l}\text { Toledo, City of } \\
\text { Department of Public Utilities. }\end{array}$ & $\mathrm{S}$ & S & $\mathrm{S}$ & -- & $\mathrm{S}$ & S & $\mathbf{S}$ & -- \\
\hline $\begin{array}{l}\text { Warren, City of } \\
\text { Division of Water. }\end{array}$ & s & s & $\mathrm{S}$ & $\mathrm{s}$ & -- & -- & $\mathbf{S}$ & -- \\
\hline $\begin{array}{l}\text { Zanesville, City of } \\
\text { Division of Water. }\end{array}$ & G & G & G & G & G & -- & -- & -- \\
\hline $\begin{array}{l}\text { Hamilton County Park District } \\
\text { Resource Quality Department } \\
\text { Cincinnati, Ohio. }\end{array}$ & $\mathbf{S}$ & -- & -- & $\mathrm{s}$ & -- & -- & -- & -- \\
\hline $\begin{array}{l}\text { Wood County } \\
\text { Sanitary Engineer Department } \\
\text { Bowling Green, Ohio. }\end{array}$ & -- & G & -- & -- & G & -- & -- & -- \\
\hline \multicolumn{9}{|l|}{ Academic institutions: } \\
\hline $\begin{array}{l}\text { Heidelberg College } \\
\text { Water Quality Laboratory } \\
\text { Tiffin, Ohio. }\end{array}$ & $\mathbf{S}$ & $\mathrm{s}$ & -- & $\mathbf{S}$ & $\mathrm{S}$ & -- & -- & $\mathrm{S}$ \\
\hline $\begin{array}{l}\text { Kent State University } \\
\text { Biological Sciences Department } \\
\text { Kent, Ohio. }\end{array}$ & $\mathrm{s}$ & -- & -- & S & -- & -- & $\mathrm{s}$ & -- \\
\hline $\begin{array}{l}\text { Miami University } \\
\text { Department of Zoology } \\
\text { Oxford, Ohio }\end{array}$ & -- & $\mathbf{S}$ & $\mathbf{S}$ & -- & -- & -- & S & -- \\
\hline $\begin{array}{l}\text { Ohio State University } \\
\text { Agricultural Engineering Department } \\
\text { Columbus, Ohio. }\end{array}$ & $\mathbf{S}$ & $\mathbf{S}$ & $\mathbf{S}$ & $\mathrm{S}$ & $\mathrm{S}$ & -- & $\mathbf{S}$ & -- \\
\hline $\begin{array}{l}\text { University of Cincinnati } \\
\text { Biological Sciences Department } \\
\text { Institute of Environmental Health } \\
\text { Cincinnati, Ohio. }\end{array}$ & S & -- & -- & -- & $\mathrm{s}$ & -- & $\mathrm{S}$ & -- \\
\hline $\begin{array}{l}\text { Wright State University } \\
\text { Department of Geological Sciences } \\
\text { Dayton, Ohio. }\end{array}$ & G & $\mathbf{G}$ & G & -- & G & -- & -- & -- \\
\hline
\end{tabular}


Table 9.--U.S. Geological Survey laboratory codes, detection limits, and costs for measurements and analyses used to determine estimated laboratory costs

[ --, not applicable; *, varies with organic species, range $5.0-30.0$; **, varies with organic species, range, $0.01-1.0 ; \mathrm{mg} / \mathrm{L}$, milligram per liter; $\mu \mathrm{S} / \mathrm{cm}$, microsiemens per centimeter at $25^{\circ}$ Celsius; $\mathrm{C}$, Celsius; $\mu \mathrm{g} / \mathrm{g}$, micrograms per gram; $\mu \mathrm{g} / \mathrm{L}$, micrograms per liter; $\mathrm{mL}$, milliliters]

\begin{tabular}{llc}
\hline $\begin{array}{c}\text { Laboratory } \\
\text { code }\end{array}$ & $\begin{array}{c}\text { Property or } \\
\text { constituent }\end{array}$ & $\begin{array}{c}\text { Detection } \\
\text { limit }\end{array}$ \\
\hline
\end{tabular}

\section{Physical-property}

\begin{tabular}{llcc}
\hline LC0068 & pH, laboratory (standard units) total & 1 & 1.35 \\
-- & Dissolved oxygen 1 &.- & 1.35 \\
LC0050 & Turbidity (nephelometric-turibidity units) total & .05 & 4.70 \\
LC0070 & Alkalinity (mg/L as CaCO3) dissolved & 1 & 4.80 \\
LC0069 & Specific conductance, laboratory $(\mu \mathrm{S} / \mathrm{cm})$ & 1 & 1.35 \\
& & 13.55 \\
\hline
\end{tabular}

Inorganic constituents

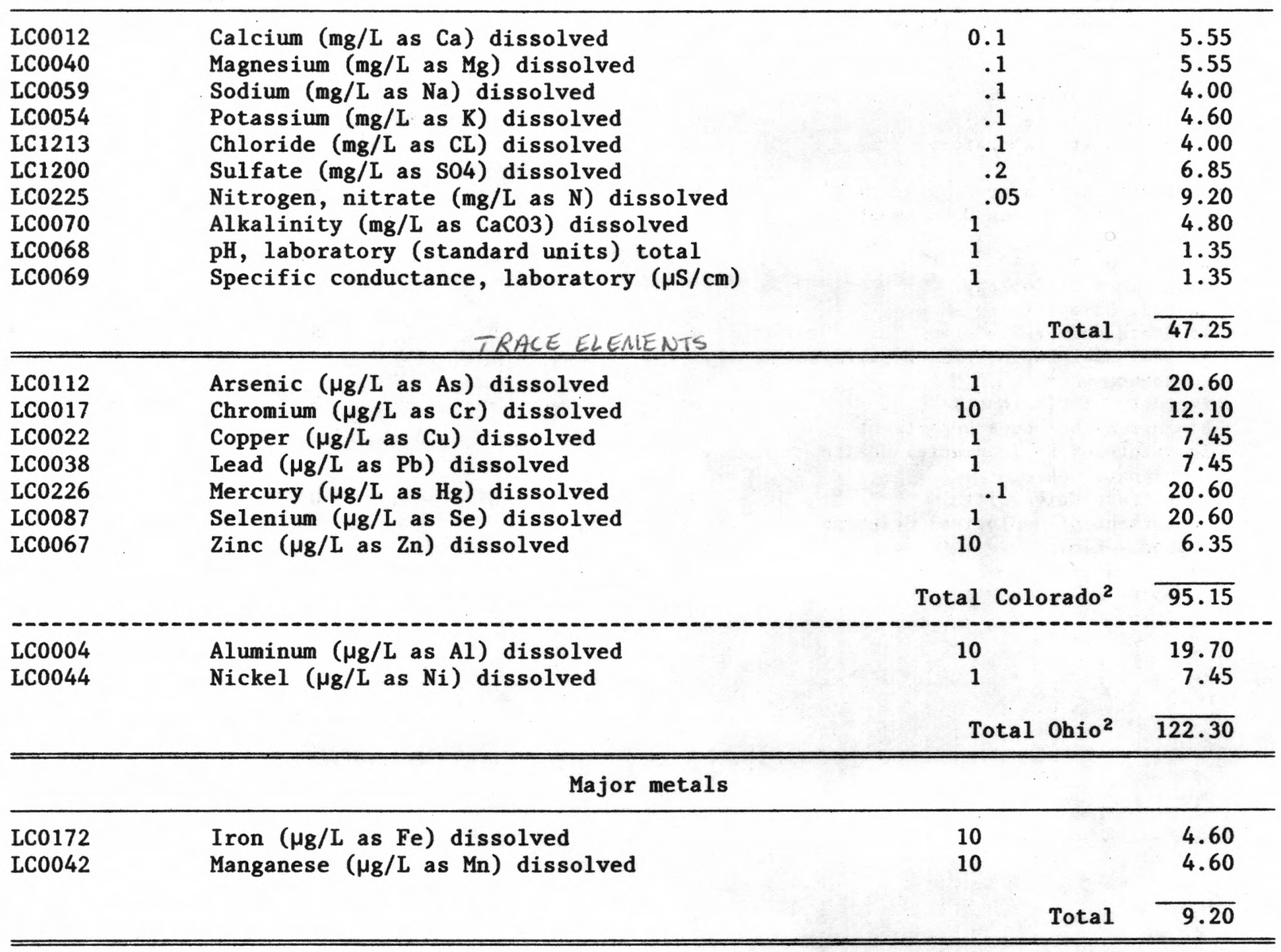


Table 9.--U.S. Geological Survey laboratory codes, detection limits, and custs for measurements and analyses used to determine estimated laboratory costs--Continued

\begin{tabular}{|c|c|c|c|}
\hline $\begin{array}{l}\text { Laboratory } \\
\text { code }\end{array}$ & $\begin{array}{l}\text { Property or } \\
\text { constituent }\end{array}$ & $\begin{array}{c}\text { Detection } \\
\text { limit }\end{array}$ & $\begin{array}{c}\text { Costs } \\
1984 \\
\text { (dollars) }\end{array}$ \\
\hline \multicolumn{4}{|c|}{ Nutrients } \\
\hline LC0301 & Nitrogen, ammonia ( $\mathrm{mg} / \mathrm{L}$ as $\mathrm{N}$ ) dissolved & 0.01 & 4.60 \\
\hline LCO 160 & Nitrogen, nitrite ( $\mathrm{mg} / \mathrm{L}$ as $\mathrm{N})$ dissolved & .01 & 4.60 \\
\hline LC1208 & Nitrogen, nitrite plus nitrate ( $\mathrm{mg} / \mathrm{L}$ as $\mathrm{N}$ ) dissolved & .01 & 4.60 \\
\hline LC0128 & Phosphorus (mg/L as P) dissolved & .01 & 12.95 \\
\hline LC0162 & Phosphorus, orthophosphate (mg/L as P) dissolved & .01 & 4.60 \\
\hline \multirow[t]{2}{*}{ LC0268 } & Nitrogen, ammonia plus organic (mg/L as $\mathrm{N})$ dissolved & .1 & 12.10 \\
\hline & & Total & 43.45 \\
\hline
\end{tabular}

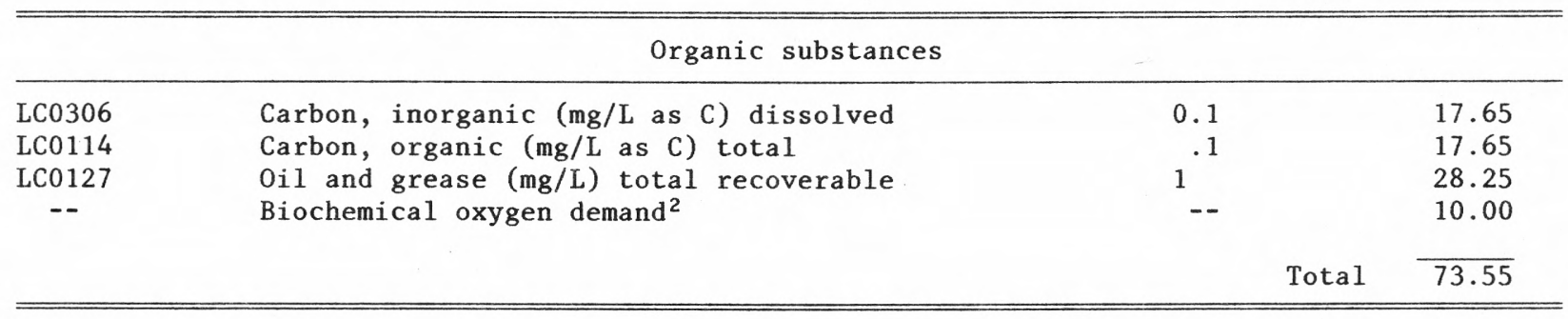

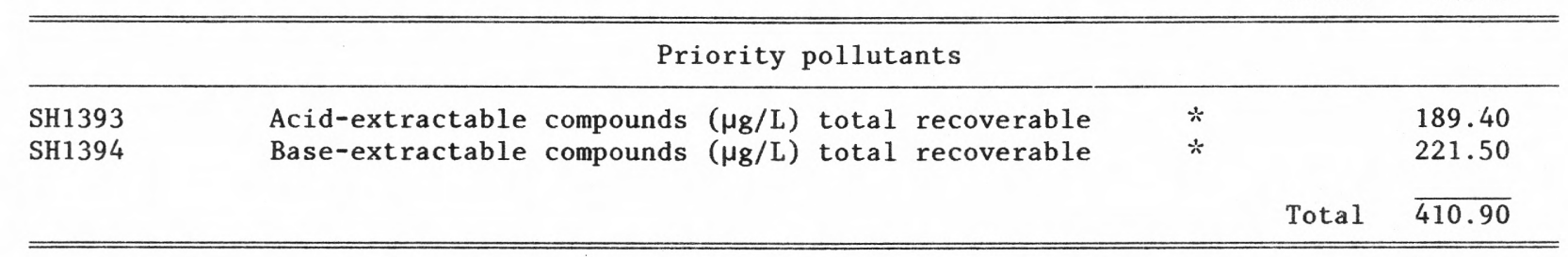

\begin{tabular}{|c|c|c|c|c|}
\hline \multicolumn{5}{|c|}{ Pesticides } \\
\hline SH1304 & Chlorophenoxy acid herbicides $(\mu g / L)$ total recoverable & 0.01 & & 188.30 \\
\hline SH1324 & $\begin{array}{l}\text { Organochlorine insecticides with gross } \mathrm{PCB} \text { and } \mathrm{PCN} \\
(\mu \mathrm{g} / \mathrm{L}) \text { total recoverable }\end{array}$ & $* *$ & & 113.40 \\
\hline & & & Total & 301.70 \\
\hline \multicolumn{5}{|c|}{ Radiochemicals } \\
\hline LC0446 & $\begin{array}{l}\text { Gross alpha radioactivity ( } \mu \mathrm{g} / \mathrm{g} \text { as } \mathrm{U} \text { natural) } \\
\text { suspended }\end{array}$ & 0.4 & & 26.75 \\
\hline \multicolumn{5}{|c|}{ Biota } \\
\hline-- & $\begin{array}{l}\text { Coliform bacteria, fecal }{ }^{3} \text { (colonies } / 100 \mathrm{~mL} \text { ) } \\
\left.\text { Coliform bacteria, streptococcal }{ }^{3} \text { (colonies } / 100 \mathrm{~mL}\right) \\
\left.\text { Coliform bacteria, total }{ }^{3} \text { (colonies } / 100 \mathrm{~mL}\right)\end{array}$ & $\begin{array}{l}-- \\
-- \\
--\end{array}$ & & $\begin{array}{l}7.50 \\
7.50 \\
7.50\end{array}$ \\
\hline & & & Total & 22.50 \\
\hline
\end{tabular}

\section{Sediment}

Suspended concentrations ${ }^{2} \quad \ldots$

${ }^{1}$ Based on charges for similar metered measurements.

${ }^{2}$ Trace-element cost factors differ between Colorado and Ohio because of differences in specific constituents most frequently analyzed.

${ }^{3}$ Based on charges by U.S. Geological Survey laboratory in Columbus, Ohio. 
Table 10.--Number of surface-water samples and estimated costs of: all measurements and analyses reported; those meeting either the ambient conditions or the data-availability criteria; and

those meeting both screening criteria, by source of data, Colorado, 1984

[Samples collected to meet permit requirements not included; cost estimates are based on 1984 U.S. Geological Survey laboratory costs]

\begin{tabular}{|c|c|c|c|c|c|c|c|c|}
\hline \multirow[b]{2}{*}{ Source of data } & \multicolumn{2}{|c|}{ All samples } & \multicolumn{2}{|c|}{ Ambient conditions } & \multicolumn{2}{|c|}{ Data availability } & \multicolumn{2}{|c|}{$\begin{array}{l}\text { Total meeting } \\
\text { both criteria }\end{array}$} \\
\hline & $\begin{array}{l}\text { Number of } \\
\text { samples }\end{array}$ & $\begin{array}{l}\text { Estimated } \\
\text { cost } \\
\text { (thousands } \\
\text { of dollars) }\end{array}$ & $\begin{array}{l}\text { Number of } \\
\text { samples }\end{array}$ & $\begin{array}{c}\text { Estimated } \\
\text { cost } \\
\text { (thousands } \\
\text { of dollars) }\end{array}$ & $\begin{array}{l}\text { Number of } \\
\text { samples }\end{array}$ & $\begin{array}{c}\text { Estimated } \\
\text { cost } \\
\text { (thousands } \\
\text { of dollars) }\end{array}$ & $\begin{array}{l}\text { Number of } \\
\text { samples }\end{array}$ & $\begin{array}{l}\text { Estimated } \\
\text { cost } \\
\text { (thousands } \\
\text { of dollars) }\end{array}$ \\
\hline U.S. Geological Survey. & 18,080 & 446 & 18,080 & 446 & 18,080 & 446 & 18,080 & 446 \\
\hline $\begin{array}{l}\text { Other Department of the } \\
\text { Interior agencies. }\end{array}$ & 6,560 & 213 & 6,340 & 205 & 6,560 & 213 & 6,340 & 205 \\
\hline $\begin{array}{l}\text { U.S. Environmental } \\
\text { Protection Agency. }\end{array}$ & 830 & 96 & 0 & 0 & 180 & 7 & 0 & 0 \\
\hline Other Federal agencies. & 4,950 & 157 & 4,950 & 157 & 3,390 & 103 & 3,390 & 103 \\
\hline Total, Federal agencies. & 30,420 & 912 & 29,370 & 808 & 28,210 & 769 & 27,810 & 754 \\
\hline $\begin{array}{l}\text { Colorado Department of } \\
\text { Health. }\end{array}$ & 69,440 & 2,626 & 67,550 & 2,556 & 69,200 & 2,622 & 67,310 & 2,552 \\
\hline Other State agencies. & 3,640 & 145 & 3,640 & 145 & 3,640 & 145 & 3,640 & 145 \\
\hline Total, State agencies. & 73,080 & 2,771 & 71,190 & 2,701 & 72,840 & 2,767 & 70,950 & 2,697 \\
\hline Regional: Intrastate agencies. & 16,490 & 495 & 15,320 & 446 & 15,320 & 446 & 15,320 & 446 \\
\hline Local agencies. & 41,780 & 1,670 & 31,680 & 1,271 & 39,160 & 1,565 & 29,060 & 1,165 \\
\hline Academic institutions. & 2,730 & 101 & 2,730 & 101 & 2,330 & 90 & 2,330 & 90 \\
\hline Subtotals, all organizations. & 164,500 & 5,949 & 150,290 & 5,327 & 157,860 & 5,637 & 145,470 & 5,152 \\
\hline Subtotals, permit-required. & 143,620 & 5,159 & 0 & 0 & 71,390 & 1,794 & 0 & 0 \\
\hline Totals (rounded) & 308,120 & 11,110 & 150,290 & 5,330 & 229,250 & 7,431 & 145,470 & 5,152 \\
\hline
\end{tabular}


Table 11.--Number of ground-water samples and estimated costs of: all measurements and analyses reported; those meeting either the ambient conditions or the data-availability criteria; and those meeting both screening criteria, by source of data, Colorado, 1984

[Samples collected to meet permit requirements not included; cost estimates are based on 1984 U.S. Geological Survey laboratory costs]

\begin{tabular}{|c|c|c|c|c|c|c|c|c|c|}
\hline & \multirow[b]{2}{*}{ Source of data } & \multicolumn{2}{|c|}{ All samples } & \multicolumn{2}{|c|}{ Ambient conditions } & \multicolumn{2}{|c|}{ Data availability } & \multicolumn{2}{|c|}{$\begin{array}{l}\text { Total meeting } \\
\text { both criteria }\end{array}$} \\
\hline & & $\begin{array}{l}\text { Number of } \\
\text { samples }\end{array}$ & $\begin{array}{l}\text { Estimated } \\
\text { cost } \\
\text { (thousands } \\
\text { of dollars) }\end{array}$ & $\begin{array}{l}\text { Number of } \\
\text { samples }\end{array}$ & $\begin{array}{l}\text { Estimated } \\
\text { cost } \\
\text { (thousands } \\
\text { of dollars) }\end{array}$ & $\begin{array}{l}\text { Number of } \\
\text { samples }\end{array}$ & $\begin{array}{l}\text { Estimated } \\
\text { cost } \\
\text { (thousands } \\
\text { of dollars) }\end{array}$ & $\begin{array}{l}\text { Number of } \\
\text { samples }\end{array}$ & $\begin{array}{l}\text { Estimated } \\
\text { cost } \\
\text { (thousands } \\
\text { of dollars) }\end{array}$ \\
\hline \multirow[t]{5}{*}{ Federal: } & U.S. Geological Survey. & 1,880 & 84 & 1,880 & 84 & 1,880 & 84 & 1,880 & 84 \\
\hline & $\begin{array}{l}\text { Other Department of the } \\
\text { Interior agencies. }\end{array}$ & 4,930 & 155 & 4,930 & 155 & 4,930 & 155 & 4,930 & 155 \\
\hline & $\begin{array}{l}\text { U.S. Environmental } \\
\text { Protection Agency. }\end{array}$ & 1,530 & 224 & 20 & 4 & 0 & 0 & 0 & 0 \\
\hline & Other Federal agencies. & 5,480 & 807 & 5,480 & 807 & 1,900 & 91 & 1,900 & 91 \\
\hline & Total, Federal agencies. & 13,820 & 1,270 & 12,310 & 1,050 & 8,710 & 330 & 8,710 & 330 \\
\hline \multirow[t]{3}{*}{ State: } & $\begin{array}{l}\text { Colorado Department of } \\
\text { Health. }\end{array}$ & 460 & 23 & 260 & 12 & 280 & 15 & 80 & 4 \\
\hline & Other State agencies. & 0 & 0 & 0 & 0 & 0 & 0 & 0 & 0 \\
\hline & Total, State agencies. & 460 & 23 & 260 & 12 & 280 & 15 & 80 & 4 \\
\hline Regional: & Intrastate agencies. & 0 & 0 & 0 & 0 & 0 & 0 & 0 & 0 \\
\hline \multicolumn{2}{|c|}{ Local agencies. } & 3,500 & 158 & 3,450 & 156 & 3,380 & 143 & 3,330 & 141 \\
\hline \multicolumn{2}{|c|}{ Academic institutions. } & 190 & 6 & 190 & 6 & 190 & 6 & 190 & 6 \\
\hline \multicolumn{2}{|c|}{ Subtotals, all organizations. } & 17,970 & 1,457 & 16,210 & 1,224 & 12,560 & 494 & 12,310 & 481 \\
\hline \multicolumn{2}{|c|}{ Subtotals, permit-required. } & 13,110 & 919 & 0 & 0 & 13,110 & 919 & 0 & 0 \\
\hline & Totals (rounded) & 31,080 & 2,380 & 16,210 & 1,220 & 25,670 & 1,410 & 12,310 & 480 \\
\hline
\end{tabular}


Table 12.--Number of surface-water samples and estimated costs of: those meeting both the ambient conditions and the data-availability criteria and either the location, quality assurance, or the computerized criteria; and those meeting all five, by source of data, Colorado, 1984

[Samples collected to meet permit requirements not included; cost estimates are based on 1984 U.S. Geological Survey laboratory costs]

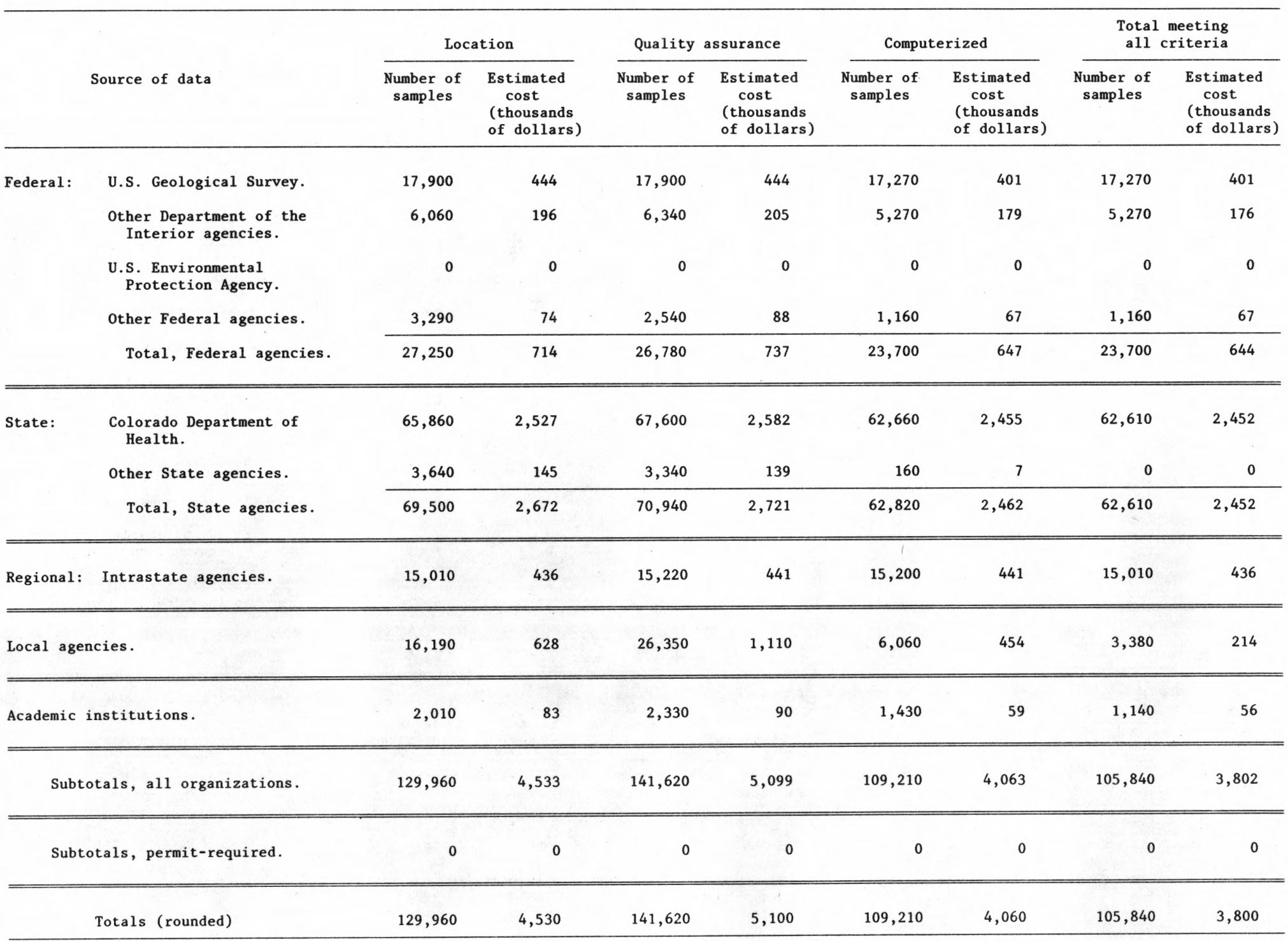


Table 13.--Number of ground-water samples and estimated costs of: those meeting both the ambient conditions and the data-availability criteria and either the location, quality assurance, or

the computerized criteria; and those meeting all five, by source of data, Colorado, 1984

[Samples collected to meet permit requirements not included; cost estimates are based on 1984 U.S. Geological Survey laboratory costs]

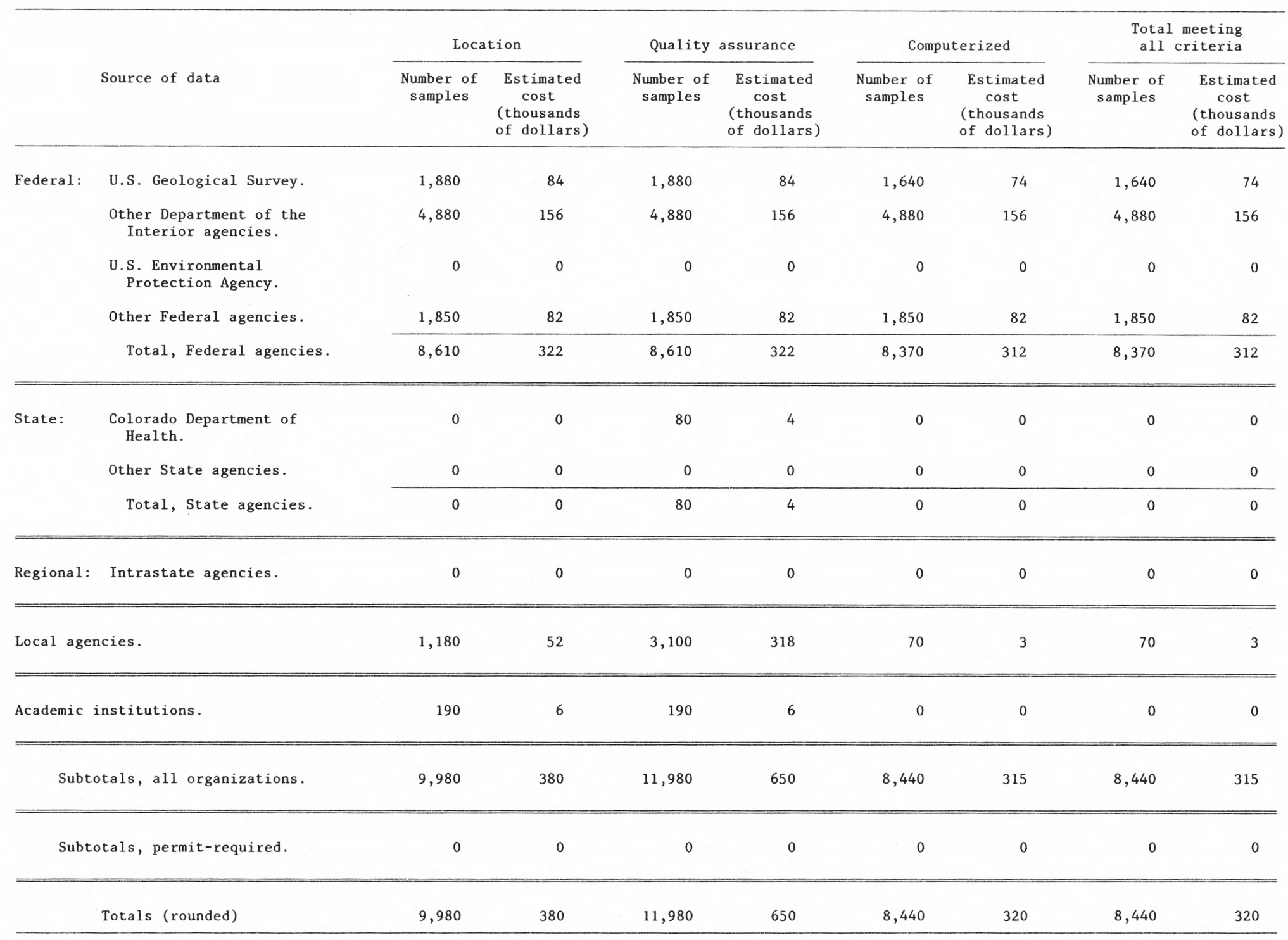


Table 14.--Estimated surface-water-quality laboratory costs for ambient and compliance-and-enforcement programs,

after screening, for physical properties and major-constituent groups, Colorado, 1984

[All costs are reported in thousands of dollars; cost estimates are based on 1984 U.S. Geological Survey laboratory costs]

\begin{tabular}{|c|c|c|c|c|c|c|c|c|c|c|c|c|}
\hline \multirow[b]{2}{*}{$\begin{array}{l}\text { Source of } \\
\text { data }\end{array}$} & \multicolumn{12}{|c|}{ Constituent group } \\
\hline & $\begin{array}{l}\text { Physical } \\
\text { properties }\end{array}$ & $\begin{array}{l}\text { Inorganic } \\
\text { constituents }\end{array}$ & $\begin{array}{l}\text { Trace } \\
\text { elements }\end{array}$ & $\begin{array}{l}\text { Major } \\
\text { metals }\end{array}$ & Nutrients & $\begin{array}{l}\text { Organic } \\
\text { substances }\end{array}$ & $\begin{array}{l}\text { Priority } \\
\text { pollutants }\end{array}$ & Pesticides & $\begin{array}{l}\text { Radio- } \\
\text { chemicals }\end{array}$ & Biota & Sediment & Total \\
\hline \multicolumn{13}{|l|}{ Federal: } \\
\hline $\begin{array}{l}\text { U.S. Geological } \\
\text { Survey. }\end{array}$ & 139 & 72 & 62 & 5 & 73 & 16 & 7 & 2 & 2 & 15 & 8 & 401 \\
\hline $\begin{array}{l}\text { Other Department } \\
\text { of the Interior } \\
\text { agencies. }\end{array}$ & 31 & 107 & 15 & 1 & 5 & 14 & 0 & 0 & 0 & 3 & 0 & 176 \\
\hline $\begin{array}{l}\text { U.S. Environmental } \\
\text { Protection Agency. }\end{array}$ & . & 0 & 0 & 0 & 0 & 0 & 0 & 0 & 0 & 0 & 0 & 0 \\
\hline Other Federal & 2 & 6 & 10 & 1 & 3 & 3 & 23 & 17 & 0 & 0 & 2 & 67 \\
\hline $\begin{array}{l}\text { Total, Federal } \\
\text { agencies. }\end{array}$ & 172 & 185 & 87 & 7 & 81 & 33 & 30 & 19 & 2 & 18 & 10 & 644 \\
\hline
\end{tabular}

State:

\begin{tabular}{|c|c|c|c|c|c|c|c|c|c|c|c|c|}
\hline $\begin{array}{l}\text { Colorado } \\
\text { Department } \\
\text { of Health }\end{array}$ & 222 & 827 & 402 & 31 & 490 & 375 & 0 & 0 & 1 & 104 & 0 & 2,452 \\
\hline Other State & 0 & 0 & 0 & 0 & 0 & 0 & 0 & 0 & 0 & 0 & 0 & 0 \\
\hline $\begin{array}{l}\text { Total, State } \\
\text { agencies. }\end{array}$ & 222 & 827 & 402 & 31 & 490 & 375 & 0 & 0 & 1 & 104 & 0 & 2,452 \\
\hline $\begin{array}{l}\text { Regional: Intra- } \\
\text { state agencies. }\end{array}$ & 80 & 178 & 50 & 5 & 23 & 23 & 0 & 0 & 0 & 77 & 0 & 436 \\
\hline Local agencies. & 0 & 31 & 50 & 2 & 20 & 31 & 59 & 0 & 0 & 21 & 0 & 214 \\
\hline $\begin{array}{l}\text { Academic } \\
\text { institutions. }\end{array}$ & 5 & 17 & 34 & 0 & 0 & 0 & 0 & 0 & 0 & 0 & 0 & 56 \\
\hline $\begin{array}{l}\text { Total (rounded), } \\
\text { all organizations. }\end{array}$ & 480 & 1,240 & 620 & 40 & 610 & 460 & 90 & 20 & 3 & 220 & 10 & 3,800 \\
\hline
\end{tabular}


Table 15.--Estimated ground-water-quality laboratory costs for ambient and compliance-and-enforcement programs, after screening, for physical properties and major-constituent groups, Colorado, 1984

[All costs are reported in thousands of dollars; cost estimates are based on 1984 U.S. Geological Survey laboratory costs]

\begin{tabular}{|c|c|c|c|c|c|c|c|c|c|c|c|}
\hline \multirow[b]{2}{*}{$\begin{array}{l}\text { Source of } \\
\text { data }\end{array}$} & \multicolumn{11}{|c|}{ Constituent group } \\
\hline & $\begin{array}{l}\text { Physical } \\
\text { properties }\end{array}$ & $\begin{array}{l}\text { Inorganic } \\
\text { constituents }\end{array}$ & $\begin{array}{l}\text { Trace } \\
\text { elements }\end{array}$ & $\begin{array}{l}\text { Major } \\
\text { metals }\end{array}$ & Nutrients & $\begin{array}{l}\text { Organic } \\
\text { substances }\end{array}$ & $\begin{array}{l}\text { Priority } \\
\text { pollutants }\end{array}$ & Pesticides & $\begin{array}{l}\text { Radio- } \\
\text { chemicals }\end{array}$ & Biota & Total \\
\hline \multicolumn{12}{|l|}{ Federal: } \\
\hline $\begin{array}{l}\text { U.S. Geological } \\
\text { Survey. }\end{array}$ & 4 & 13 & 23 & 2 & 12 & 8 & 8 & 0 & 1 & 3 & 74 \\
\hline $\begin{array}{l}\text { Other Department } \\
\text { of the Interior } \\
\text { agencies. }\end{array}$ & 38 & 51 & 30 & 3 & 7 & 12 & 4 & 11 & 0 & 0 & 156 \\
\hline $\begin{array}{l}\text { U.S. Environmental } \\
\text { Protection Agency. }\end{array}$ & . & 0 & 0 & 0 & 0 & 0 & 0 & 0 & 0 & 0 & 0 \\
\hline Other Federal & 3 & 52 & 20 & 2 & 0 & 3 & 0 & 0 & 2 & 0 & 82 \\
\hline $\begin{array}{l}\text { Total, Federal } \\
\text { agencies. }\end{array}$ & 45 & 116 & 73 & 7 & 19 & 23 & 12 & 11 & 3 & 3 & 312 \\
\hline State: & & & & & & & & & & & \\
\hline $\begin{array}{l}\text { Colorado } \\
\text { Department } \\
\text { of Health }\end{array}$ & 0 & 0 & 0 & 0 & 0 & 0 & 0 & 0 & 0 & 0 & 0 \\
\hline $\begin{array}{c}\text { Other State } \\
\text { agencies. }\end{array}$ & 0 & 0 & 0 & 0 & 0 & 0 & 0 & 0 & 0 & 0 & 0 \\
\hline $\begin{array}{c}\text { Total, State } \\
\text { agencies. }\end{array}$ & 0 & 0 & 0 & 0 & 0 & 0 & 0 & 0 & 0 & 0 & 0 \\
\hline $\begin{array}{l}\text { Regional: Intra- } \\
\text { state agencies. }\end{array}$ & 0 & 0 & 0 & 0 & 0 & 0 & 0 & 0 & 0 & 0 & 0 \\
\hline Local agencies. & 0 & 1 & 1 & 0 & 0 & 0 & 0 & 0 & 0 & 0 & 3 \\
\hline $\begin{array}{l}\text { Academic } \\
\text { institutions. }\end{array}$ & 0 & 0 & 0 & 0 & 0 & 0 & 0 & 0 & 0 & 0 & 0 \\
\hline $\begin{array}{l}\text { Total (rounded), } \\
\text { all organizations }\end{array}$ & ns. 40 & 120 & 70 & 10 & 20 & 20 & 10 & 10 & 3 & 3 & 320 \\
\hline
\end{tabular}


Table 16.--Number of surface-water samples and estimated costs of: all measurements and analyses reported; those meeting ither the ambient conditions or the data-availability criteria; and those meeting both screening criteria, by source of data, ohio, 1984

[Samples collected to meet permit requirements not included; cost estimates are based on 1984 U.S. Geological Survey laboratory costs]

\begin{tabular}{|c|c|c|c|c|c|c|c|c|}
\hline \multirow[b]{2}{*}{ Source of data } & \multicolumn{2}{|c|}{ All samples } & \multicolumn{2}{|c|}{ Ambient conditions } & \multicolumn{2}{|c|}{ Data availability } & \multicolumn{2}{|c|}{$\begin{array}{l}\text { Total meeting } \\
\text { both criteria }\end{array}$} \\
\hline & $\begin{array}{l}\text { Number of } \\
\text { samples }\end{array}$ & $\begin{array}{c}\text { Estimated } \\
\text { cost } \\
\text { (thousands } \\
\text { of dollars) }\end{array}$ & $\begin{array}{l}\text { Number of } \\
\text { samples }\end{array}$ & $\begin{array}{l}\text { Estimated } \\
\text { cost } \\
\text { (thousands } \\
\text { of dollars) }\end{array}$ & $\begin{array}{l}\text { Number of } \\
\text { samples }\end{array}$ & $\begin{array}{c}\text { Estimated } \\
\text { cost } \\
\text { (thousands } \\
\text { of dollars) }\end{array}$ & $\begin{array}{l}\text { Number of } \\
\text { samples }\end{array}$ & $\begin{array}{l}\text { Estimated } \\
\text { cost } \\
\text { (thousands } \\
\text { of dollars) }\end{array}$ \\
\hline Federal: U.S. Geological Survey. & 7,740 & 133 & 7,740 & 133 & 7,740 & 133 & 7,740 & 133 \\
\hline $\begin{array}{l}\text { Other Department of the } \\
\text { Interior agencies. }\end{array}$ & 80 & 2 & 60 & 1 & 80 & 2 & 60 & 1 \\
\hline $\begin{array}{l}\text { U.S. Environmental } \\
\text { Protection Agency. }\end{array}$ & 100 & 5 & 0 & 0 & 0 & 0 & 0 & 0 \\
\hline Other Federal agencies. & 3,440 & 152 & 3,440 & 152 & 3,320 & 146 & 3,320 & 146 \\
\hline Total, Federal agencies. & 11,360 & 292 & 11,240 & 286 & 11,140 & 281 & 11,120 & 280 \\
\hline $\begin{array}{l}\text { Ohio Environmental } \\
\text { Protection Agency. }\end{array}$ & 33,680 & 1,870 & 31,790 & 1,673 & 31,720 & 1,621 & 29,830 & 1,425 \\
\hline Other State agencies. & 3,970 & 129 & 3,070 & 120 & 3,970 & 129 & 2,770 & 106 \\
\hline Total, State agencies. & 37,650 & 2,000 & 34,860 & 1,793 & 35,690 & 1,750 & 32,600 & 1,531 \\
\hline Regional: Interstate agencies. & 4,000 & 385 & 4,000 & 385 & 4,000 & 385 & 4,000 & 385 \\
\hline Local agencies. & 78,590 & 5,407 & 78,590 & 5,407 & 43,650 & 1,596 & 43,650 & 1,596 \\
\hline Academic institutions. & 12,930 & 1,084 & 12,910 & 1,079 & 11,190 & 1,032 & 11,190 & 1,032 \\
\hline Subtotals, all organizations. & 144,530 & 9,168 & 141,600 & 8,950 & 105,670 & 5,044 & 102,560 & 4,824 \\
\hline Subtotals, permit-required. & $1,002,300$ & 35,431 & 0 & 0 & $1,002,300$ & 35,431 & 0 & 0 \\
\hline Totals (rounded) & $1,146,830$ & 44,600 & 141,600 & 8,950 & $1,107,970$ & 40,470 & 102,560 & 4,820 \\
\hline
\end{tabular}


Table 17.--Number of ground-water samples and estimated costs of: all measurements and analyses reported; those meeting either the ambient conditions or the data-availability criteria; and

those meeting both screening criteria, by source of data, ohio, 1984

[Samples collected to meet permit requirements not included; cost estimates are based on 1984 U.S. Geological Survey laboratory costs]

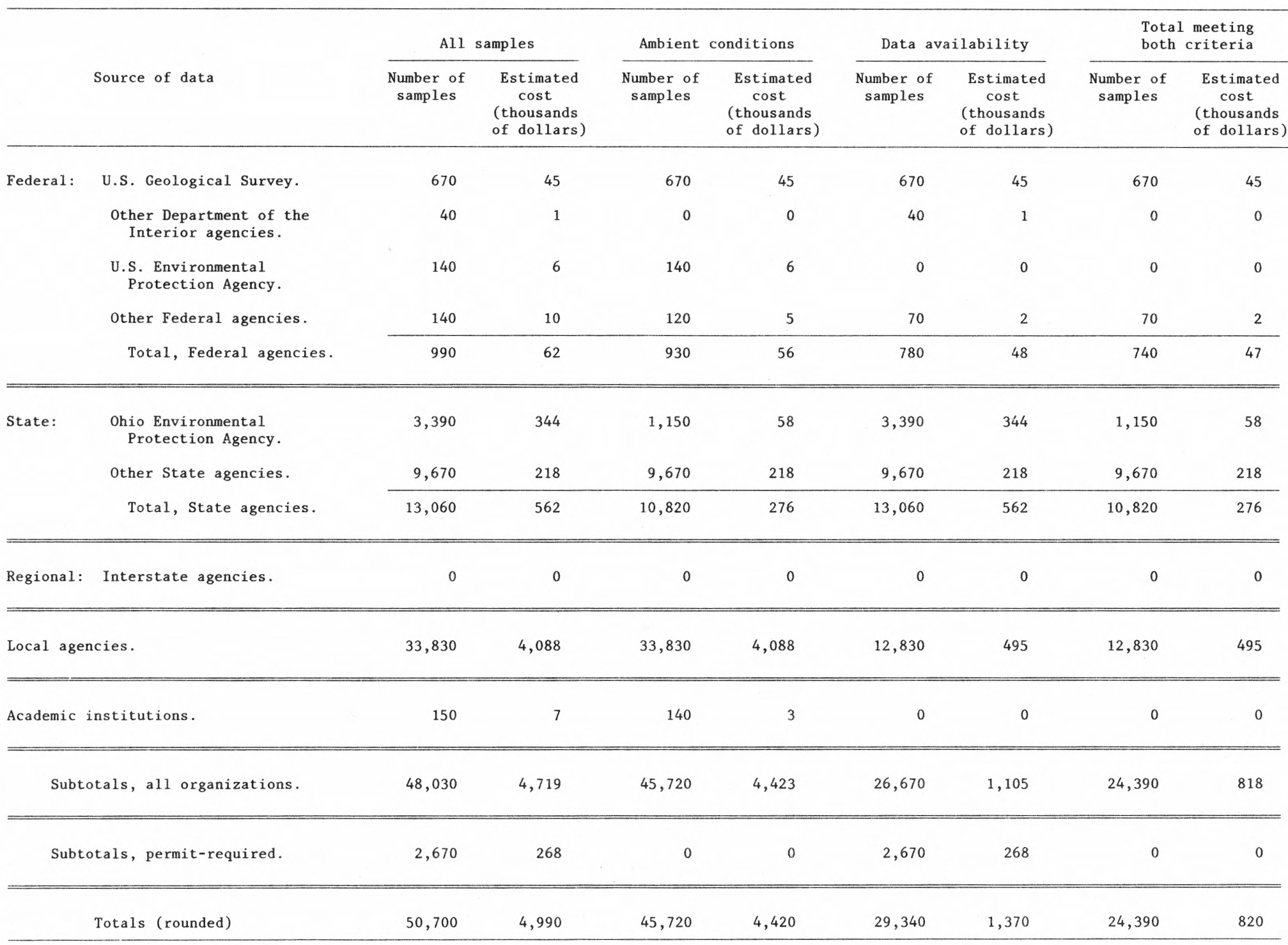


Table 18.--Number of surface-water samples and estimated costs of: those meeting both the ambient conditions and the data-availability criteria and either the location, quality assurance, or

the computerized criteria; and those meeting all five, by source of data, Ohio, 1984

[Samples collected to meet permit requirements not included; cost estimates are based on 1984 U.S. Geological Survey laboratory costs]

\begin{tabular}{|c|c|c|c|c|c|c|c|c|}
\hline \multirow[b]{2}{*}{ Source of data } & \multicolumn{2}{|c|}{ Location } & \multicolumn{2}{|c|}{ Quality assurance } & \multicolumn{2}{|c|}{ Computerized } & \multicolumn{2}{|c|}{$\begin{array}{l}\text { Total meeting } \\
\text { all criteria }\end{array}$} \\
\hline & $\begin{array}{l}\text { Number of } \\
\text { samples }\end{array}$ & $\begin{array}{c}\text { Estimated } \\
\text { cost } \\
\text { (thousands } \\
\text { of dollars) }\end{array}$ & $\begin{array}{l}\text { Number of } \\
\text { samples }\end{array}$ & $\begin{array}{c}\text { Estimated } \\
\text { cost } \\
\text { (thousands } \\
\text { of dollars) }\end{array}$ & $\begin{array}{l}\text { Number of } \\
\text { samples }\end{array}$ & $\begin{array}{l}\text { Estimated } \\
\text { cost } \\
\text { (thousands } \\
\text { of dollars) }\end{array}$ & $\begin{array}{l}\text { Number of } \\
\text { samples }\end{array}$ & $\begin{array}{l}\text { Estimated } \\
\text { cost } \\
\text { (thousands } \\
\text { of dollars) }\end{array}$ \\
\hline Federal: U.S. Geological Survey. & 7,740 & 133 & 7,740 & 133 & 7,740 & 133 & 7,740 & 133 \\
\hline $\begin{array}{l}\text { Other Department of the } \\
\text { Interior agencies. }\end{array}$ & 60 & 1 & 60 & 1 & 60 & 1 & 60 & 1 \\
\hline $\begin{array}{l}\text { U.S. Environmental } \\
\text { Protection Agency. }\end{array}$ & 0 & 0 & 0 & 0 & 0 & 0 & 0 & 0 \\
\hline Other Federal agencies. & 3,320 & 146 & 3,320 & 146 & 3,270 & 144 & 3,270 & 144 \\
\hline Total, Federal agencies. & 11,120 & 280 & 11,120 & 280 & 11,070 & 278 & 11,070 & 278 \\
\hline $\begin{array}{l}\text { Ohio Environmental } \\
\text { Protection Agency. }\end{array}$ & 29,530 & 1,417 & 29,830 & 1,425 & 29,530 & 1,417 & 29,530 & 1,417 \\
\hline Other State agencies. & 2,770 & 106 & 2,670 & 102 & 0 & 0 & 0 & 0 \\
\hline Total, State agencies. & 32,300 & 1,523 & 32,500 & 1,527 & 29,530 & 1,417 & 29,530 & 1,417 \\
\hline Regional: Interstate agencies. & 4,000 & 385 & 4,000 & 385 & 4,000 & 385 & 4,000 & 385 \\
\hline Local agencies. & 43,640 & 1,595 & 43,600 & 1,595 & 2,080 & 83 & 2,080 & 83 \\
\hline Academic institutions. & 11,190 & 1,032 & 11,190 & 1,032 & 9,600 & 817 & 9,600 & 817 \\
\hline Subtotals, all organizations. & 102,250 & 4,815 & 102,410 & 4,819 & 56,280 & 2,980 & 56,280 & 2,980 \\
\hline Subtotals, permit-required. & 0 & 0 & 0 & 0 & 0 & 0 & 0 & 0 \\
\hline Totals (rounded) & 102,250 & 4,820 & 102,410 & 4,820 & 56,280 & 2,980 & 56,280 & 2,980 \\
\hline
\end{tabular}


Table 19.--Number of ground-water samples and estimated costs of: those meeting both the ambient conditions and the data-availability criteria and either the location, quality assurance, or

the computerized criteria; and those meeting all five, by source of data, Ohio, 1984

[Samples collected to meet permit requirements not included; cost estimates are based on 1984 U.S. Geological Survey laboratory costs]

\begin{tabular}{|c|c|c|c|c|c|c|c|c|c|}
\hline & \multirow[b]{2}{*}{ Source of data } & \multicolumn{2}{|c|}{ Location } & \multicolumn{2}{|c|}{ Quality assurance } & \multicolumn{2}{|c|}{ Computerized } & \multicolumn{2}{|c|}{$\begin{array}{l}\text { Total meeting } \\
\text { all criteria }\end{array}$} \\
\hline & & $\begin{array}{l}\text { Number of } \\
\text { samples }\end{array}$ & $\begin{array}{l}\text { Estimated } \\
\text { cost } \\
\text { (thousands } \\
\text { of dollars) }\end{array}$ & $\begin{array}{l}\text { Number of } \\
\text { samples }\end{array}$ & $\begin{array}{l}\text { Estimated } \\
\text { cost } \\
\text { (thousands } \\
\text { of dollars) }\end{array}$ & $\begin{array}{l}\text { Number of } \\
\text { samples }\end{array}$ & $\begin{array}{l}\text { Estimated } \\
\text { cost } \\
\text { (thousands } \\
\text { of dollars) }\end{array}$ & $\begin{array}{l}\text { Number of } \\
\text { samples }\end{array}$ & $\begin{array}{l}\text { Estimated } \\
\text { cost } \\
\text { (thousands } \\
\text { of dollars) }\end{array}$ \\
\hline \multirow[t]{5}{*}{ Federal: } & U.S. Geological Survey. & 670 & 45 & 670 & 45 & 670 & 45 & 670 & 45 \\
\hline & $\begin{array}{l}\text { Other Department of the } \\
\text { Interior agencies. }\end{array}$ & 0 & 0 & 0 & 0 & 0 & 0 & 0 & 0 \\
\hline & $\begin{array}{l}\text { U.S. Environmental } \\
\text { Protection Agency. }\end{array}$ & 0 & 0 & 0 & 0 & 0 & 0 & 0 & 0 \\
\hline & Other Federal agencies. & 70 & 2 & 70 & 2 & 0 & 0 & 0 & 0 \\
\hline & Total, Federal agencies. & 740 & 47 & 740 & 47 & 670 & 45 & 670 & 45 \\
\hline \multirow[t]{3}{*}{ State: } & $\begin{array}{l}\text { Ohio Environmental } \\
\text { Protection Agency. }\end{array}$ & 1,150 & 58 & 1,150 & 58 & 0 & 0 & 0 & 0 \\
\hline & Other State agencies. & 810 & 18 & 9,670 & 218 & 0 & 0 & 0 & 0 \\
\hline & Total, State agencies. & 1,960 & 76 & 10,820 & 276 & 0 & 0 & 0 & 0 \\
\hline Regional: & Interstate agencies. & 0 & 0 & 0 & 0 & 0 & 0 & 0 & 0 \\
\hline \multicolumn{2}{|c|}{ Local agencies. } & 12,830 & 495 & 12,830 & 495 & 0 & 0 & 0 & 0 \\
\hline \multicolumn{2}{|c|}{ Academic institutions. } & 0 & 0 & 0 & 0 & 0 & 0 & 0 & 0 \\
\hline \multicolumn{2}{|c|}{ Subtotals, all organizations. } & 15,530 & 618 & 24,390 & 818 & 670 & 45 & 670 & 45 \\
\hline \multicolumn{2}{|c|}{ Subtotals, permit-required } & 0 & 0 & 0 & 0 & 0 & 0 & 0 & 0 \\
\hline & otals (rounded) & 15,530 & 620 & 24,390 & 820 & 670 & 40 & 670 & 40 \\
\hline
\end{tabular}


Table 20.--Estimated surface-water-quality laboratory costs for ambient and compliance-and-enforcement programs,

after screening, for physical properties and major-constituent groups, ohio, 1984

[A1l costs are reported in thousands of dollars; cost estimates are based on 1984 U.S. Geological Survey laboratory costs]

\begin{tabular}{|c|c|c|c|c|c|c|c|c|c|c|c|c|}
\hline \multirow[b]{2}{*}{$\begin{array}{c}\text { Source of } \\
\text { data }\end{array}$} & \multicolumn{12}{|c|}{ Constituent group } \\
\hline & $\begin{array}{l}\text { Physical } \\
\text { properties }\end{array}$ & $\begin{array}{l}\text { Inorganic } \\
\text { constituents }\end{array}$ & $\begin{array}{l}\text { Trace } \\
\text { elements }\end{array}$ & $\begin{array}{l}\text { Major } \\
\text { metals }\end{array}$ & Nutrients & $\begin{array}{l}\text { Organic } \\
\text { substances }\end{array}$ & $\begin{array}{l}\text { Priority } \\
\text { pollutants }\end{array}$ & Pesticides & $\begin{array}{l}\text { Radio- } \\
\text { chemicals }\end{array}$ & Biota & Sediment & Total \\
\hline \multicolumn{13}{|l|}{ Federal: } \\
\hline $\begin{array}{l}\text { U.S. Geological } \\
\text { Survey. }\end{array}$ & 52 & 11 & 25 & 2 & 8 & 8 & 11 & 0 & 0 & 2 & 14 & 133 \\
\hline $\begin{array}{l}\text { Other Department } \\
\text { of the Interior } \\
\text { agencies. }\end{array}$ & 0 & 0 & 0 & 0 & 0 & 0 & 0 & 0 & 0 & 1 & 0 & 1 \\
\hline $\begin{array}{l}\text { U.S. Environmental } \\
\text { Protection Agency. }\end{array}$ & . & 0 & 0 & 0 & 0 & 0 & 0 & 0 & 0 & 0 & 0 & 0 \\
\hline Other Federal & 10 & 34 & 70 & 5 & 20 & 0 & 0 & 0 & 0 & 4 & 0 & 144 \\
\hline $\begin{array}{l}\text { Total, Federal } \\
\text { agencies. }\end{array}$ & 62 & 45 & 95 & 7 & 28 & 8 & 11 & 0 & 0 & 7 & 14 & 278 \\
\hline
\end{tabular}

\section{State:}

\begin{tabular}{|c|c|c|c|c|c|c|c|c|c|c|c|c|}
\hline $\begin{array}{l}\text { Ohio Environmental } \\
\text { Protection Agency. }\end{array}$ & 66 & 186 & 489 & 24 & 223 & 208 & 123 & 0 & 0 & 88 & 9 & 1,417 \\
\hline Other State & 0 & 0 & 0 & 0 & 0 & 0 & 0 & 0 & 0 & 0 & 0 & 0 \\
\hline $\begin{array}{c}\text { Total, State } \\
\text { agencies. }\end{array}$ & 66 & 186 & 489 & 24 & 223 & 208 & 123 & 0 & 0 & 88 & 9 & 1,417 \\
\hline $\begin{array}{l}\text { Regional: Inter- } \\
\text { state agencies. }\end{array}$ & 32 & 8 & 22 & 2 & 6 & 10 & 303 & 0 & 0 & 3 & 0 & 385 \\
\hline Local agencies. & 6 & 20 & 0 & 0 & 18 & 31 & 0 & 0 & 0 & 9 & 0 & 83 \\
\hline $\begin{array}{l}\text { Academic } \\
\quad \text { institutions. }\end{array}$ & 0 & 113 & 0 & 0 & 104 & 44 & 0 & 543 & 0 & 0 & 12 & 817 \\
\hline $\begin{array}{l}\text { Total (rounded) } \\
\text { all organizations. }\end{array}$ & 170 & 37 & 610 & 30 & 380 & 300 & 440 & 540 & 0 & 110 & 40 & 2,980 \\
\hline
\end{tabular}


Table 21.--Estimated ground-water-quality laboratory costs for ambient and compliance-and-enforcement programs,

after screening, for physical properties and major-constituent groups, Ohio, 1984

[All costs are reported in thousands of dollars; cost estimates are based on 1984 U.S. Geological Survey laboratory costs]

\begin{tabular}{|c|c|c|c|c|c|c|c|c|c|c|c|}
\hline \multirow[b]{2}{*}{$\begin{array}{l}\text { Source of } \\
\text { data }\end{array}$} & \multicolumn{11}{|c|}{ Constituent group } \\
\hline & $\begin{array}{l}\text { Physical } \\
\text { properties }\end{array}$ & $\begin{array}{l}\text { Inorganic } \\
\text { constituents }\end{array}$ & $\begin{array}{l}\text { Trace } \\
\text { elements }\end{array}$ & $\begin{array}{l}\text { Major } \\
\text { metals }\end{array}$ & Nutrients & $\begin{array}{l}\text { Organic } \\
\text { substances }\end{array}$ & $\begin{array}{l}\text { Priority } \\
\text { pollutants }\end{array}$ & Pesticides & $\begin{array}{l}\text { Radio- } \\
\text { chemicals }\end{array}$ & Biota & Total \\
\hline \multicolumn{12}{|l|}{ Federal: } \\
\hline $\begin{array}{l}\text { U.S. Geological } \\
\text { Survey. }\end{array}$ & 2 & 5 & 11 & 1 & 4 & 6 & 15 & 0 & 1 & 0 & 45 \\
\hline $\begin{array}{l}\text { Other Department } \\
\text { of the Interior } \\
\text { agencies. }\end{array}$ & 0 & 0 & 0 & 0 & 0 & 0 & 0 & 0 & 0 & 0 & 0 \\
\hline $\begin{array}{l}\text { U.S. Environmental } \\
\text { Protection Agency. }\end{array}$ & $y$. & 0 & 0 & 0 & 0 & 0 & 0 & 0 & 0 & 0 & 0 \\
\hline Other Federal & 0 & 0 & 0 & 0 & 0 & 0 & 0 & 0 & 0 & 0 & 0 \\
\hline $\begin{array}{l}\text { Total, Federal } \\
\text { agencies. }\end{array}$ & 2 & 5 & 11 & 1 & 4 & 6 & 15 & 0 & 1 & 0 & 45 \\
\hline
\end{tabular}

State:

\begin{tabular}{|c|c|c|c|c|c|c|c|c|c|c|c|}
\hline $\begin{array}{l}\text { Ohio Environmental } \\
\text { Protection Agency. }\end{array}$ & 0 & 0 & 0 & 0 & 0 & 0 & 0 & 0 & 0 & 0 & 0 \\
\hline Other State & 0 & 0 & 0 & 0 & 0 & 0 & 0 & 0 & 0 & 0 & 0 \\
\hline $\begin{array}{l}\text { Total, State } \\
\text { agencies. }\end{array}$ & 0 & 0 & 0 & 0 & 0 & 0 & 0 & 0 & 0 & 0 & 0 \\
\hline $\begin{array}{l}\text { Regional: Inter- } \\
\text { state agencies. }\end{array}$ & 0 & 0 & 0 & 0 & 0 & 0 & 0 & 0 & 0 & 0 & 0 \\
\hline Local agencies. & 0 & 0 & 0 & 0 & 0 & 0 & 0 & 0 & 0 & 0 & 0 \\
\hline $\begin{array}{l}\text { Academic } \\
\text { institutions. }\end{array}$ & 0 & 0 & 0 & 0 & 0 & 0 & 0 & 0 & 0 & 0 & 0 \\
\hline $\begin{array}{l}\text { Total (rounded) } \\
\text { all organizations. }\end{array}$ & 2 & 5 & 11 & 1 & 4 & 6 & 15 & 0 & 1 & 0 & 45 \\
\hline
\end{tabular}



